\title{
Financial Resource Management and Its Influence on Students Academic Performance in Public Secondary Schools In Langata Sub-County, Nairobi County-Kenya
}

\author{
Martin Okoth Odide \\ Department of Postgraduate in Education \\ The Catholic University of Eastern Africa Nairobi-Kenya
}

\begin{abstract}
The aim of the study was to examine the influence of financial resource management on the students' academic performance in public secondary schools in Lang'ata sub-county, Nairobi County- Kenya. The study was premised on behavioural leadership theory propounded by Kurl Lewin in the 1930's which emphasizes that people can learn to become leaders through training and observation. The following research questions were formulated to guide the study: What is the influence of budget management on students' academic performance in public secondary schools in Lang'ata sub - county, Nairobi County? ; What is the influence of financial controls on the students' academic performance in public secondary schools in Lang'ata sub - county, Nairobi County? ; What challenges do Principals of Public secondary schools face in the management of finances?; What strategies, with regard to financial resource management, are used by Principals of Public secondary schools in Lang'ata sub-county to improve academic performance?
\end{abstract}

Descriptive research design was adopted for the study. The study was conducted in public secondary schools. The target population comprised five (5) public secondary schools. Purposive sampling technique was used to draw 5 principals, 5 bursars, 5 B.O.M representatives, 15 H.O.Ds, 30 teachers and 200 students' representatives giving a total of 260 participants. Data was collected using questionnaires, interview schedules, and observation schedules. A pilot test was conducted on some staff to ensure the validity of the instruments. Data obtained through open-ended questionnaires was analysed using descriptive and inferential statistics. Ethical issues such as confidentiality, informed consent, privacy and anonymity were given paramount considerations.

\section{Introduction}

\subsection{Background to the Problem}

Education is the foundation of sustainable development in any institution or country. It has a central place in the transformation of individual lives as well as world economies. Every country allocates a considerable portion of its resources to education every year aiming at empowering the people with necessary skills, knowledge and expertise. Orodho and Njeru (2005) noted that education is a basic tool for social, cultural, political and economic development. Their view was earlier pointed out during the $45^{\text {th }}$ Session of International Conference on Education held in Geneva (1996) which defined education as a person's individual and social development that the person gains in the teaching and learning process in school. Learning is a long term process that involves investment of resources. The outcome, which among other parameters, is measured in terms of students' academic performance, is treated with a lot of expectations.

The academic performance of the learners gives an impression about the gains, which according to United Nations International Children's Education Fund, should lead to a person's intellectual, emotional, spiritual and physical abilities to mature, hence enabling him/her to participate fully in community affairs (UNICEF, 1996). In order to achieve desirable outcomes, the management of resources in institutions of learning plays a central role. Secondary school principals are entrusted by the Ministry of Education to manage the 
resources in their schools. They are the chief accounting officers managing all physical, human, and financial resources in their school set up (Nyongesa, 2007). This gives them the mandate to mobilize resources and to ensure school effectiveness through improving students' academic performance.

However, despite all the efforts by the government and other stakeholders, the area of management, especially financial management has been wanting. There have been quarries in secondary schools regarding expenditures of public funds, tendering processes, conflict of interest in school equipment supplies, misappropriation, diversion of funds, embezzlement, and mismanagement among others. Where resource management issues have been explicit, the performance of learners has been deteriorating. The situation is no different in Langata sub-county, where the majority are slum dwellers, whose livelihood and future depend heavily on education. This study is about resource management and its influence on students' academic performance in public secondary schools in Lang'ata sub-county, Nairobi County.

Resources in an institution of learning are broad based. This study focused on the financial resources in public secondary schools and how they influence students' academic performance. Mwenda and Gachocho, (2003), observe that financial management in public schools are concerned with defining the goals, and developing programs that will convert such goals into monetary values. This implies that proper financial management is very essential for the success of an institution.

For any educational institution to run effectively there is need for adequate resources, and efficient management leadership. Scholars have attempted to explain resources in various ways. Woodford (2003) for instance, sees a resource as a useful or valuable possession or quality of a country, organization or person. Coleman and Anderson (2001) divided education resources into two main categories: those used to provide support services such as the running costs of the buildings, administration and management and those for operational core of teaching and learning like physical or tangible resources.

The main resources available for organizations are human, financial, physical and informational (Sherman,1996). Nsubuga (1978) identified school teaching and learning resources to include buildings particularly classrooms with lockable doors for storage of materials, teaching aids like textbooks, visual aids and other scholastic materials. Mintzberg (1979) holds that resources directly utilized in teaching and learning are clearly classrooms and curriculum support resources such as books, stationery materials equipment, wall pictures, blackboards, audio-visual aids, globes, maps, atlases, concrete objects and classroom environment. For successful running of a school, finance plays a central role.

Management is equally important in institutional efficiency. Slocum (2005) observes that management includes the tasks and activities involved in directing an organization or institution. Directing an institution of learning is a fundamental role that requires training, leadership skills, objective judgment and accountability. Management generally is anchored on four pillars of planning, organizing, leading and controlling. Other scholars also have contributed to the subject of management. Hellriegel (2005) suggests that management involves designing and carrying out plans, getting things done and working effectively with people. Viba and Brevis (2002) further noted that management is getting things done, effectively and efficiently, through and with other people. Efficiency includes team work, timely communication, motivation, proper utilization of the available resources, and excellent performance of tasks and achievement of the institutional goals among others.

In Africa, school principals are appointed mainly based on their past teaching experiences. Although the teaching experience is necessary, it should not be the only requirement for a teacher to be appointed principal. (Oplatka,2004). Basic financial management skills are equally important Nyamweya (2006), notes that in African countries, financial management skills induction courses and support are usually limited. World Bank report (2005) pointed out that in Kenya, households meet $20 \%$ of primary, $60 \%$ of secondary and $8 \%$ of university education costs. The introduction of free secondary education and the $100 \%$ transition policy has lessened the burden, yet the quality, infrastructure, personnel, and accountability are still wanting. 
In Langata sub-county, most principals work in poorly equipped schools. The available resources therefore require careful allocation and use in order to achieve good academic performance.

Nyaga (2003), further noted that management is the utilization of physical and human resources through cooperation efforts in order to realize the established goals. It is accomplished by planning, organizing, staffing, directing and controlling. Management in education broadly involves the running of educational institution. It includes school finances, physical infrastructure, programs, staff, students and services to the community. Okumbe (1999), on the other hand sees management as the process of designing developing and affecting educational objectives and resources so as to achieve predefined educational goals. These explanations provide insight on the importance of resource management in institutions with the aim of maximizing the intended output.

From the global perspective, attempts have been made to establish the influence of resource management on students' academic performance. The World Bank (2008), observes that management, from a broader perspective, is concerned with the processes and practices designed to realize objectives at all levels of the education system: who carries out what responsibilities, how the various parts of the system communicate with each other, and how checks and balances work among the levels. Proper management guarantees effective utilization of resources by ensuring that allocations are used for the right purposes.

In order to reinforce efficiency and accountability, many countries have decentralized financial management to schools. For instance, in the United States, there is emphasis on accountability from all institutions, especially institutions of higher learning. Performance funding policies influenced state budgets and priorities for resource allocation at public institutions. A study conducted in France (Crouch \&Winker, 2008), established that there is a drive towards decentralization of financial resources to schools in a bid to enhance their management. Another study conducted in Sweden observed that tight budgetary control affects management behaviour in public school and universities throughout the country. Despite the expectations placed on the financial resource management to bring the much needed change, studies have shown that in some institutions resources are mismanaged and misappropriated by those in charge (Rosen \& Gayer, 2010).

The problem of misappropriation, non-adherence to the budget, missing institutional goals and unsatisfactory performance has led scholars to be preoccupied with the question of financial management Asemah (2010) observes that financial management in schools implies the identification of the sources of school finance, fund raising, methods of funds collection, and effective application of revenues to the school system in order to achieve the stated goals and objectives Brockington (1993), notes that finance management is that part of the total management function concerned with the effective and efficient raising and use of funds. Okwori (2003) holds that financial management as recognition and respect for authorities, regulations and practices governing the receiving, keeping and spending of funds while Kwaghbo (2008) argues that financial management is planning, organizing, coordinating, directing and collecting of payments in such a way as to achieve organizational goals. This task requires school administrators to have sufficient knowledge of financial management techniques in order to be effective financial managers. The financial manager is one who forecasts, plans, budgets and implements the budget according to specified estimates so that funds are effectively used to achieve the desired objectives of the school. A budget is therefore an important guideline for successful management of school finances.

Other scholars have added their voice to the issue of financial resource management in institutions of learning. Campher (2002) says financial management in education includes economics and accounting as applied to schools, as well as a broad field of study that touches on many disciplines as part of the system. Oosthuizen (2003) on the other hand sees financial management in education as the distribution and use of money for the purpose of providing educational services and producing learner achievement. Financial management in contemporary education management thus aims to estimate the needs of educational training, obtain finances in accordance with the estimated needs and to administer the finances. 
Financial management is therefore an essential element in the proper management of an institution of learning. Burke (2001), points out that a lot of resources are involved in running organizations and therefore to get value from those investments require a lot of transparency from those in charge. Due to the major contribution it has on development, the education sector is treated with high priority in most countries. According to UNESCO (2000), low levels of education are not good for any nation. This observation has inspired some countries like USA, Canada, Britain, Egypt, and Nigeria to fully fund education.

Hubbard (2007) shows that the introduction of Universal Primary Education (UPE) in Uganda in 1997, brought about remarkable change in the structure of school financing, such as the abolition of the compulsory parental contributions that had previously been a mainstay of the school funding. In order to compensate schools for the loss of this funding, the school capitation grant was rebranded as the UPE Capitation Grant, and its nominal value per student was doubled to Ugsh 5000 for primary $1-3$ and Ugsh 8,100 for primary $4-7$. In practice, the pre-1997 grant was a supplement to school fees while after 1997 the grant replaced school fees, so in effect the two grants were of very different value and function. Later this grant was replaced with a standard amount per school with a small capitation grant added based on each learner enrolled (IOB, 2008). The rough doubling of the school population between 1995 and 2001 (from 2.6 million to over 6 million) further doubled the national spend on the grant. This surge in enrolment, which continued with school enrolment reaching 7.6 million in 2003 (IOB, 2008), put huge pressure on the public funds and the capacity of the Ugandan education system which turned to the World Bank for help.

In Kenya, funding of secondary education is largely shared between the parents and government. According to the Ministry of Education, public secondary schools consume 23\% of the Ministry's budget annually. The management of funds in public schools is under the principal with the approval of the Board of Management, (Department of Education and Culture, 2009). Their responsibility is to ensure proper utilization of the available resources so that their schools perform well in both academics and in other areas. However, it has been observed that some school principals operate without following the budget or laid down procedures in terms of financial resource management.

Effective financial management requires that school managers should possess and apply basic financial management skills. Owen (2006) supports this view by saying that financial numeracy is a core skill for all managers. Most financial management skills involve the allocation of resources and the setting of targets, expectations and priorities. The main financial skills required by all school managers to enable them perform their duties successfully are budgeting, budget management and management of costs. Moreover, communication plays an integral part of financial management.

Bisschoff and Mestry (2007) explain that internal communication on financial school management is important to ensure that all internal stakeholders know when to make their submissions and how to spend funds allocated to them. Financial management is therefore a process of several activities such as identification, mobilization, acquisition, accumulation, analysis, reporting, interpretation, and communication. Financial management at a secondary school is a process of ensuring that the managers organize, delegate and control the funds of the school in such a way that it achieves its intended goals and objectives.

According to Ogbonnaya (2000), the main purpose of financial management in secondary schools is to ensure that the funds are used in the most effective manner and in the best interest of the institution. School Principals are the chief accounting officers of their respective secondary schools. They are supposed to generate funds internally to run their schools as well as ensure that funds provided by the government and donor partners are properly managed. Principals cite lack of enough funds to run their schools as a challenge. Inadequate teaching and learning resources among other necessities have led to the growing interest of both the public and government on how funds provided for the implementation of secondary school programmes are managed. The public and the relevant stakeholders in education expect school principals to ensure proper management of the funds provided, with the aim of improving quality and scope of education and to ascertain progressive performance of students. Despite the checks and balances, schools 
still suffer from inadequate allocation of funds to various vote heads, missing funds, embezzlement, corruption in the tendering process and substandard accounting systems which eventually lead to poor academic performance.

Resource management as an area of interest cuts across the education spectrum. From the regional perspective for instance, it has been observed that the management of school funds has been a challenge in Zimbabwe. Studies have shown that school principals and school development committees have failed to efficiently manage school funds and to co-ordinate activities in the schools. This is due to poor or lack of training by the Ministry of Education (Caldwell, 2004). Chatiza, (2011) documented that school heads in Mashonaland East province have cases of mismanagement of funds. Wushe, Ndlovu and Shenje (2014) in their analysis of basic management and financial skills by school development committees in Zimbabwe maintained that efforts by school principals, development committees, the community and other stakeholders are necessary for proper decision making and utilization of the school resources. They noted that school administrators of secondary schools in Harare lacked financial skills required for the prudent management of school funds.

In Nigeria, Mgbodile (2000) observed that the delay of disbursement of funds to institutions, lack of adequate training for the educational heads, and negligence of school financial clerks are some of the factors that cause poor management of funds. Bua and Adzongo (2014) also noted that poor state of schools in Benue State in Nigeria was as a result of inability to generate revenue internally and misuse of the available resources. Resources, being the backbone of the institution, have a vital function towards achieving the intended goals. According to Ogbomanya (2000), the main purpose of financial management is to ensure funds are used in the most efficient and effective manner. Poor management of the available resources leads to misappropriations, diversion of funds from the prioritized projects and embezzlement among other vices. In the end, the set goals are never realized hence adversely affecting students' academic performance.

The people entrusted with the responsibility of running institutions are very important in ensuring quality resource management and the achievement of better students' academic performance. Studies have shown that $73 \%$ of the social sector expenditure and about $40 \%$ of the national recurrent expenditure in Kenya goes to education. Where large sums of money are involved, there is need for high level of accountability. Transparency International Report (2009) indicates that the education system in Kenya continues to be plagued by financial mismanagement risks that threaten the quality of education. This is happening even after the enactment of Public Officer Ethics Act of 2003 which stipulates that money given out as imprest ought to be accounted for and any major purchases in a school to be done through the tendering process.

School principals play important roles in the day to day management of their institutions. Urba and Brevis (2002) state that during the course of their daily work, principals typically fulfil several roles. Hellriegel (2005), says that the principals under the direction of their district, take a leadership role in the daily operation of a school. Principals are responsible for the organization and management of individual schools. Mestry (2004) mentions that in terms of financial matters, the principal should have various kinds of school accounts and records kept properly and should make the best use of funds for the benefit of learners in consultation with the appropriate structures.

Functions of the financial manager, such as the school principal include the following: to accept responsibility for the effective, well-organized reasonably priced and translucent use of the assets and funds of the school; and is also accountable to gather all money that is owed to or payable to the department; to stay away from unofficial, unbalanced, unrewarding and wasteful expenditure and losses resulting from illegal behaviour; to put in place a system or structure that will coordinate the assessment of all big capital projects correctly, preceding a final decision that is made on the project; the principal as accounting financial officer is liable for the supervision, including the safeguarding and maintenance of the resources, and for the administration of the liabilities of the school, and also to administer accessible working capital efficiently and economically. 
When a learner is admitted to a public school, the principal must notify the parents of the amount of the annual school contributions to be paid and the procedures for applying for exemption; notify the parent the fact that he/she is liable for the payment of school contributions unless he/she has been exempted from the payment thereof; to maintain financial and deliberations of the Board of Management as confidential.

In addition, Anderson and Briggs (2001) state that the Board of Management and the principal are likely to be involved in some, or all, of the following activities: preparing a budget for the school; considering and controlling the costs of certain educational activities; deciding resource allocation within the school or department; securing additional funding and/or resources for the school through entrepreneurial activities; responding to the needs and concerns of parents; developing and maintaining links with local businesses, industry and commerce, preparing and implementing a marketing strategy for the school; and accountability for delegated spending and demonstrating values for money. The school principal works in close collaboration with the Board of Management who has the foremost authority regarding the finances of the school.

According to Olembo (2005), the school principals are responsible for effective and efficient management of school finances in order to promote delivery of services. It is however noted that the school principals underperform in their role of financial management. This may be due to employing less qualified staff with inadequate training in maintaining financial records, financial controls and who fail to adhere to accounting procedures (Ministry of Education, 2007). The government of Kenya has prioritized the financial management in schools and institutions of learning. This has been through financial regulations such as financial management policies that involve imprest management, auditing, credit management policies, inventory management policies among others. Considerable number of schools followed the government recommended financial management policies, especially in Gucha district (Maronga, Weda and Kangere, 2013). These guidelines have assisted schools to obtain desirable financial status hence improving in all sectors including academics but there are still fundamental issues that need to be addressed in order to guarantee long term achievement.

Financial management is therefore a control system that determines how to use the available resources optimally to produce quality results often seen in the students' performance in exams, both internally and nationally. The importance of a control system lies first in the design of the programs outlined to achieve the goals and secondly in the skills and abilities of the people involved in the implementation. These explanations and points of view were helpful in the study, for they assisted to lay the foundation of understanding financial resource management in public secondary schools and how they influence students' academic performance in Lang'ata sub-county, Nairobi County.

As already alluded to by Kwaghbo (2008), a budget is a fundamental component of resource management. Without a proper budget, financial resource management would be unsustainable hence negatively affecting performance. In the following section, attention is paid to the budget and its role in the financial management of schools, teaching and learning process and the students' academic performance.

World Bank report of 1998 pointed out that although considerable time was paid to budget systems, the main concern was that, revenue and expenditure followed different patterns over the financial year and aggregate revenue tended to be below the projections on which the budget was based. These were the case in most developing countries that faced resource variability and had limited scope to smoothing consumption pattern (World Bank, 1998). Other budget management issues were based on the recognition that public budgets often differ from the accounting system used in the private sector.

The budget process in Kenya is made within the framework of the medium Term Expenditure format (MTEF). MTEF is a tool for linking policy, planning and budgeting over a medium term at the government level. It consists of a top down resource envelop and bottom up estimation of the current and medium term 
cost of existing policies. Ministry of Finance (MoF) would set ceilings for all sectors on a three-year basis. The Ministry of Education (MoE) would present education needs of the institutions upon which their bidding process is based. Incremental budgeting on a top down principle is practiced and figures are not based on cost activity plans but on available resources. Based on estimates, the Ministry of Education (MoE) would release the approved budgets (Kiringai\& West, 2002).

Public secondary schools get support from the government by getting allocation of funds to operate their activities. It is then understood the purpose is to serve society through government support. However, quality service in public secondary schools is influenced and limited by the financial allocation. Thus the budget goals of a public secondary school strongly determine its general performance, both in administrative and students' academic performance (Trentin, 2004).

The corner stone of management control process in most institutions is budgeting. Budgeting is the act of preparing a budget (Garrison \& Noreen, 2003). Budgeting is a central process of controlling accounting systems. It facilitates the effectiveness and implementation of management functions. A study conducted by Weetman (2006) found out that budgetary process contributed to planning, control, and communication and performance evaluation. The preparation of a budget forced management to implement formal planning procedures, which encouraged departments to participate in the formation of the overall budget.

Ryan (2008), suggests that management at each level are faced with the need to plan the resources under their control. The planning period identified the goals to be attained during the fiscal year, and the financial plan necessary to achieve them. The budget must be well conceived and based upon combination of historical data and future financial projections. Planning is an attempt to make today's decisions in contemplation of their futurity; it bridges the gap from where we are to where we want to be in the future (Koontz, 1998).

Budget control is achieved through the matching of actual expenditure with plans. A budget assists managers in managing and controlling the activities for which they are responsible. Planning is concerned with internal resource allocation to achieve certain objectives whereas control is concerned with the task of coordinating and using allocated resources to achieve predetermined levels of efficiency. It offers a number of control procedures such as communication, authorization of expenditure and performance evaluation (Moll, 2003). The control procedures are essential for efficiency.

The budget serves as a vehicle through which the actions of the different parts of an organization could be brought together and reconciled into a common plan without any guidance. Managers could each make their own decisions believing that they are working in the best interests of the organization. Drury, (1992) agrees that budgeting compels managers to examine the relationship between their own operations and those of other departments and in the process, identify and resolve conflict.

Weetman (2006) further observed that to ensure all the departments in the organization are kept informed of the budget process and the plans, lines of communication should be adopted and implemented. This would encourage the awareness of the importance of the budget through achieving the objectives. For an institution to function effectively there is need to have definite lines of communication so that all are informed of the plans and policies. Therefore, institutions should have clear understanding of the part they are expected to play in achieving the annual budgets.

According to Edwards (2000), a budget is one of the most important tools for decision making in the organization. Decision making included pricing education, and costing information in institutions. (Buckland, 2005) pointed out that it is difficult to produce reliable information where overheads are obviously high and where academic managers, who have no background in costing or pricing are in charge of taking decisions. 
Kenya has had a steady growth in the education sector since independence. There is a continuous increasing demand for education, which has caused an expansion of educational systems. This increasing demand has come with financial consequences which affect the schools' general performance and students' academic performance in particular. William (2013) significantly notes that the definition of academic performance extends beyond the classroom. He argues that some of the brightest students don't earn straight A's but are extremely well-rounded both in academic and extra curricula activities, succeeding at everything from music to athletics. The ability to master a diverse set of skills illustrates intelligence, curiosity and persistence - qualities attractive to universities, employers and the global community.

Rising costs of education have been caused by inflation and changes in technology. As a result, there is increased expenditure on education the world over. World Bank Sector Working Paper (1980) cited that in 1960 the world spending on education by public bodies used up to $3.2 \%$ of the world Gross National Product and it increased to $4.8 \%$ in 1974. This percentage may have more than tripled by the year 2019. With so much money invested in education, there is need for proper planning and evaluation by those in charge of schools. According to Guthrie (1988), Education needs to be more efficient and the output should offer a positive reflection of the input thus planning and evaluation are the two major stages in a cycle of events aimed at enhancing an educational organization's ability to serve its clients, that is, parents, pupils and the public.

For planning and evaluation to be successful, there is need for proper budgeting as a practical bridge between planning and evaluation. Thus the budget represents the financial crystallization of the organization's intentions. It is through budgeting that a school can decide on how to achieve the intended goals. Macharia (2002) views proper budgeting administration as a way of ensuring that resources are allocated according to what is in the budget. The school administrators and Board of Management have the responsibility of approving what is to be spent.

Frederick (2010) observes that proper resources management requires compliance to the budget. For the last two decades, the word "budget" has preoccupied managers and administrators of various institutions. Budget is perhaps the most chosen course of action by the management and staff across all sectors in the institution. Management at all levels, in the public and private sectors have used the word budget as their excuse when challenged about any decision. It is not uncommon to hear variations of the phrases "the budget does not permit", or "it's not in the approved budget" all because of the budget compliance (Frederick, 2010).

A budget is the quantitative expression of a proposed plan of action by management for a specified period and aid to coordinating what needs to be done to implement the plan. (Horngren, 2003). A budget can cover financial and non- financial aspects of the plan and serves as a blue print for the institution to follow in an upcoming period. It is an essential tool to every organization operation. It requires operating effectively and offering quality service which require incurring expenditure.

A budget is a method of accomplishing managerial tasks. It is a means of planning for various revenue streams, a control mechanism for an administration to keep from spending too much, a procedure for controlling its units, a process to coordinate the many activities that an institution undertakes, a way to communicate to all stakeholders and a summarization of the activities that the various units will undertake. It is also a technique for setting the institution priorities by allocating scarce resources to those activities that officials deem to be the most important and rationing it to those areas deemed less vital (Goldstein, 2005). School resource management is carried out by top leadership in collaboration with the stakeholders, ranging from students, staff, parents, community, the Board of Management and the Ministry of Education.

The Basic Education Act 2013 gives the Boards of Management responsibilities to run schools under their area. According to section 59(a-f) of the Education Act, the functions of the Board of Management $(\mathrm{BoM})$ include the following: Promotion of the best interests of the institution and ensure development; 
promote quality education for all pupils in accordance with the standards set by the Act or any other law; Ensure and assure the provision of proper and adequate physical facilities for the school; determine causes of pupils indiscipline and make a report to the County Education Board; facilitate and ensure the provision of guidance and counselling to all learners ; encourage the learners, teachers and non-teaching staff and others, parents and community, and other stakeholders to render voluntary services to the institution, amongst others. The Government of Kenya thus recognises the contribution of the Board of Management to quality education output through active participation in mobilization and management of resources. Their efforts positively lead to desirable performance in schools, both academically and in all other areas.

Students' academic performance is influenced by, and not limited to, the financial resources available in the school for utilization. The financial sources, especially the economic status of the parents, play a great admission role, hence affecting the eventual academic performance at the end of the four-year secondary school cycle. A study conducted by Tardif (2002) on the factors predicting children's educational outcomes found out that parents educational level was an important predictor of students' performance. A similar study conducted by Bello (1989) found out that there is a significant relationship between parents' occupation and the children's academic performance.

A study conducted by Bennell and Sayed (2002) found out that South African parents fund approximately half of all the expenditure in government schools. They also found out that financial support creates conflict among the foundation bodies who claim some recognition in the management of the schools. This becomes complex for school heads because multiple sources of finance create multiple senses of ownership. The challenge of managing a complicated school funding system seems to be similar. In South Africa as in Kenya, financial resource is often the source of conflict of interest. It is therefore imperative to find out the best ways of financial resource management in schools for optimum utilization of opportunities for excellent students' academic performance.

Educational institutions require money to achieve their objectives. The success and high performance therefore depends on the availability of funds. Udo and Akpa (2001) argue that a particular way in which education is financed largely determines how much it will cost and how much money is to be raised. Joubert and Prinsloo (2001), hold that the primary responsibility of funding public schools lies with the government out of public revenue.

A study conducted by Akpakwu (1996) found out that secondary schools in Nigeria rely on government funding. However, it has become apparent that the government funding alone cannot meet the country's educational needs due to the drop in oil prices at the global market and the rapid change in population of school going age. It has therefore become necessary to explore other sources of generating school funds as well as embark on cost-cutting initiatives and diligent management. Some of the sources of schools funding in Nigeria include government grants, school fees, Parents Teachers Association (PTA) support, school activities, and external grants from development partners.

In order to understand the financial management in secondary schools, attention will be paid to studies which have been conducted in other areas of the economy. This information will help the researcher to make better judgements and to offer valuable recommendations to the education stakeholders in Lang'ata sub-county, Nairobi County.

Kiringai and West (2002) did a study on budget reforms and the Medium Term Expenditure Framework (MTEF) in Kenya. The study reviewed various budget systems and evaluated the strengths of MTEF process and the threats to its sustained implementation in the context of developing countries like Kenya.

The study identified a number of weaknesses in the planning and budgeting process that had continued to contribute to its poor performance namely: poor forecasting ability, lack of medium-term perspective, failure to cost future resource requirements, too many budgets, excessive political interference 
in budgeting, separation of the planning and budgeting process, failure of planning groups to integrate strategic planning concerns into the budget cycle, failure of expenditure controls by line item, incremental recurrent budgeting especially on on-going programmes resulting in redundant and rising programme implementation costs, delays in issuing resources due to unforeseen changes in revenue, emergency expenditures and unplanned activities, inadequate provision for the recurrent implications of development projects; funding of recurrent activities through the development budget to attract donor funding at the expense of accountability and transparency, discrepancies between development estimates and public investment programmes, poor quality of development projects due to poor targeting, high per unit costs and low completion rates, weak accounting systems, inadequate and at times lack of monitoring and evaluating systems and failure to develop management information systems.

The paper concluded that, MTEF was a powerful tool if fully implemented and adopted as the best practice. However, that resource allocation and implementation is flawed citing the following reasons, there was lack of a comprehensive development strategy that were based on realistic national resource constraints, excessive size of the government, failure to achieve aggregate fiscal discipline and poor quality of public expenditure.

Obulemire (2006), did a study on survey of budget practices in secondary schools. The study aim was to look at benefits of budgeting by Public Secondary Schools Managers and to establish factors that secondary school consider when undertaking a budgetary process. The study established that most secondary schools do not have a strategic plan to guide them towards achievement of both long-term and short term objectives.

Students' academic performance has long preoccupied the interest of researchers as well as scholars. Many studies have been conducted to find out factors affecting the performance of students in all levels of learning. In his research on Student performance and student growth as measure of success: An evaluator's perspective and presented at annual meeting of the American educational research association New Orleans. Louisiana. 25 April, Hanson (2000) suggests that students' academic performance is affected by factors such as learning abilities, gender and race. Hijazi and Naqvi (2006) in their study on Factor Affecting Students' Performance: A case of Private Colleges conducted in Bangladesh and published in the e-journal of Sociology, found out attitude towards class attendance, time allocation for studies, and parents' level of income were the main factors that affect performance of students.

Kapur (2018) studied Factors Influencing the Student's Academic Performance in Secondary Schools in India: University of Delhi. He suggests that the major determinants of academic performance include class participation, class assignments, tests, examinations and participation in extra curricula activities. Furthermore, pressure on the teachers and administrators from stakeholders to improve academic performance has enabled schools to come up with advanced strategies. Some of the strategies include effective teaching and learning methods, use of technology, promoting extra coaching, and rewarding students for good performance.

School financial management strategies and skills reflect the level of outcome in terms of students' academic performance. Birimana and Orodho (2014), in their study conducted in Huye District - Rwanda, established that there is a positive and significant correlation between effective management of teaching and learning resources and teacher efficient classroom management, content delivery and eventual students' academic performance. They argue that resource management strategy is the efficient and effective deployment of an organization's resources when they are needed, and are very critical to enhanced academic performance in schools. Such resources may include financial resources, inventory, human skills, production resources, or information technology. It consists of analysis, decisions, and actions an organization undertakes in order to create and sustain competitive advantages (Birimana \& Orodho, 2014; Gregory, 2005). 
Matula, Mulwa and Kyalo (2018) studied the financial management for effective schools: Bridging theory and practice in Kitui County, Kenya. The study found out that although the principals' have been attending financial management skills courses organized by Kenya Education Management Institute (KEMI), most of them are not able to abide by public financial accounting instructions. (GOK, 2009; Audit Report Kitui Central District). The report noted that $10 \%$ of the principals could not prepare financial books of accounts, 30\% had incomplete cash books, 60\% had incomplete payment vouchers and $80 \%$ had inadequate training on financial management skills. (GOK: Secondary Schools, 2009) Being the managers of their institutions, principals hold a central role in financial decision process which is key to the overall performance of the institution, usually evident in the academic performance of learners.

In response to the need for improved performance in the education sector, Nairobi County, which includes Langata sub-county, in its Strategic plan (2014), emphasized prudence in finance and resource management. Gitman (2003), holds that finance is the art and the science of managing money and is concerned with the process, institutions, markets and instruments involved in the transfer of money among individuals, institutions and governments. The Finance and Economic Planning Department of Nairobi County has a vision to be a leading sector in public policy formulation, implementation, coordination, supervision and prudent resource management. The sector mission is to provide overall leadership and policy direction in resource mobilization, management and accountability for quality public service delivery. (Nairobi County Integrated Development Plan, 2014). This Development plan, in conjunction with the Kenya Vision 2030 emphasizes development and improvement of the community by providing essential services to the public through a strong, efficient and result oriented public sector policy.

It is expected that when all sectors, especially in education, work efficiently, then students' academic performance will steadily improve. These scholars allude to the fact that all students have equal chances to perform well in exams despite their conditions or stations in life. Each country allocates considerable resources to education at all levels and follows up to ensure quality deliverance and sustainable output. Langata sub-county is largely an informal settlement dominated by Kibera slam, the largest informal settlement in Africa. Due to the hard economic conditions, the learners in these settlements face many challenges in their pursuit for education. Hardships such as lack of proper sanitation, food, decent shelter and overcrowded neighborhoods affect their emotional and psychological balance hence influencing their academic performance. The majority of the residents are small business operators, casual labourers, and low income workers. They can hardly afford to educate their children in secondary schools, even with the government subsidy. The school administrators are therefore expected to manage the resources in their schools prudently so as to assist the needy students and to improve the academic performance. Despite the efforts, performances in schools differ depending on the level of management. It is against this backdrop that the study sought to establish the relationship between financial resource management and the students' academic performance in public secondary schools in Lang'ata Sub - County, Nairobi County - Kenya.

\subsection{Statement of the problem}

Management of financial resources is a major concern in Secondary schools. In Lang'ata sub-county, the same concerns surface. All resources are pegged to the budget. It follows that proper allocation and utilization of financial resources results into good performance of the school. However, this is not always the case. Public institutions which undertake budgeting on a hierarchical basis face a situation at each level in the hierarchy. There is a possibility that the original request would be changed in one way or another, causing shortages. (Heller \& Aghvelli, 2005). The Kenya Education Management Institute trains' secondary school heads on financial management skills on a regular basis, yet cases of mismanagement have been adversely reported. The continuous decline in students' academic performance, especially in schools where finances are poorly managed has led to an outcry from the stakeholders, sometimes leading to interdiction or transfer of school heads.

Furthermore, the policy of releasing recurrent and development funds to public institutions has been a hindrance to the efficient administration of institutional operations. Studies have shown that there is a 
relationship between financial resources and performance. Further studies have shown that there is a relationship between management of resources and the degree of output in an organization or institution of learning. For example, Keith (2014) conducted a study on financing education in Asia. In his work, he explored recent patterns of growth in participation in education across the Asian region. He illustrates how demand is changing and how varied the challenges of growth in access and attainment will be over the next fifteen years. The analysis indicates that, in general, universal access to a full cycle of basic education is unlikely to be sustainable unless about 5\% of GDP is allocated to education as a whole, and at least $2 \%$ for primary schooling. The situation in Asia is not far from Kenya. Despite the government capitation funding to both primary and secondary schools, there is need for further funding to address issues such as infrastructure development, staffing, and feeding programs which are key to universal access, retention and completion of basic education cycle hence contributing to a larger extent to improved academic performance.

Around the same period, Bua and Ibuh, (2014) conducted a study to investigate the impact of financial management on secondary school's administration performance in Zone A Senatorial District of Benue State-Nigeria. It was found out that prompt payment of staff salaries and allowances significantly impact on the management of secondary schools. Other studies globally have appreciated the importance of financial resources in the retention and better performance of learners. Lewin (2008) found out that students' performance substantially improved in Bangladesh after the introduction of bursaries. Keith (2008) also found out that students completion and transition rates improved significantly in the United Kingdom with the support of bursary aid.

The research in Kenya context is that a lot of resources are utilized in the administration hence targets are never realized. This is mainly because during planning stage, targets are often based on unrealistic revenue projections. Mwenda and Gachocho (2003), noted that the actual budget implementation tends to dictate policy priorities, despite the enormous resources put into the budget preparation. As a result, the institutional goals remain largely unaccomplished, schools pile up debts, the suppliers demand dues sometimes taking legal actions against the school, the teachers loose morale in their work, the students are not motivated, indiscipline is on the rise, parents reduce their support for the school, and in the end the overall performance is affected.

Most of the studies that have been done are of the views that there are challenges in the management of financial resources. In Lang'ata sub-county, like other sub-counties in the country, Kenya Certificate of Secondary Education (KCSE) results are released every year. These results are indicators of the school's performance, specifically in academics but also the quality of management strategies. This is the time when stakeholders review the school. The financial management practices of principals in Langata sub-county have become sensitive due to public and government interest in the implementation of school programmes. The public expects the school administrators to utilize the available funds effectively and to produce good academic results for their children. However, there have been cases of mismanagement, lack of initiatives to source for additional funds, non-adherence to the budget, and late remittance of government subsidies which adversely influence the academic performance of learners. It was against this backdrop that the study was premised. Therefore, this study was an attempt to establish how resource management influences students' academic performance in public secondary schools in Lan'gata sub-county, Nairobi County.

\subsection{Research Questions}

This study was guided by the following research questions:

i. What is the influence of budget management on students' academic performance in public secondary schools in Lang'ata sub - county, Nairobi County?

ii. What is the influence of financial controls on the students' academic performance in public secondary schools in Lang'ata sub - county, Nairobi County?

iii. What challenges do Principals of Public secondary schools face in the management of finances? 
iv. What strategies, with regard to financial resource management, are used by Principals of Public secondary schools in Lang'ata sub-county to improve academic performance?

\subsection{Significance of the study}

This study would be of significance to the following groups of people: To the secondary school principals, it would provide an insight into the various approaches towards efficient utilization of financial resources and how such resources could be used as students' academic performance measurements. The study would be of significance to the Ministry of Education in setting benchmarks in regard to financing of public secondary schools.

The study would be useful to the academicians for it will provide a useful basis upon which further research studies on management of financial resources and students' academic performance could be conducted. The Basic Education Act (2013) gives the Boards of Management the mandate to run schools within their area in collaboration with the County Education Boards. This national policy and legislation invites the Boards of Management of secondary schools to increase their participation in education affairs by creating a culture of effectiveness, especially in financial resource utilization. This study will give some valuable insight to the Boards of Management so that they may identify and subsequently improve on mobilization, allocation, utilization, monitoring and evaluation of their financial resource systems with the aim of improving performance, especially students' academic performance.

The contribution of parents towards the education of their children has largely been understood to mean meeting costs. Bridgemohan (2002) says that effective parental involvement is essential for success in school as well as to lessen the gap in achievement between children from high and low - income families. This study will make parents understand that timely contribution in terms of providing essential materials for their children, paying other levies not covered by the Free Secondary Education mandate, and close guidance to their children contribute significantly to the overall academic performance. It will therefore stimulate the spirit of parent- school cost sharing.

The study will create awareness among the teachers about the significance of effective utilization of the available financial resources for greater output and quality deliverance of content to the learners. It will also encourage the teachers to focus on creativity and improvisation in their areas of specialization. The students being aware of the financial challenges faced in institutions of learning will make the students to concentrate on their academic work with vigor, knowing that the challenges of today are lessons for a better tomorrow.

This study will create awareness to the communities within Lang'ata sub-county on the impact of financial resources on the academic performance of their children. It will motivate these communities to contribute generously, both materially and in kind, towards the academic excellence of their secondary schools. The results of the study will be useful to the researcher as a source of identifying grey areas for further research. It will also inform the researcher, when given the responsibility related to school administration, to understand strengths and weaknesses in financial resource management and its subsequent impact on the general students' academic performance.

\subsection{Scope and Delimitations of the Study}

This study sought to establish the relationship between financial resource management and the students' academic performance in public secondary schools in Lang'ata Sub-county. It therefore identified key attributes necessary for effective financial management such as knowledge, skills and attitudes. The reason for focusing on financial management and students' academic performance in public secondary schools is informed by the evidence gathered from contemporary literature showing that there exist challenges in public schools over the management of funds. There are cases of accumulated debts, insufficient teaching and learning materials, students' unrest, unsatisfactory academic performance, parents' protests, transfer of school heads and eventual decline in the general quality of education. It is against this backdrop that this study attempted to find specific ways of ensuring efficient financial management in public 
secondary schools and as a result improve the academic performance of students through quality sustainable education.

Lang'ata sub-county is part of the larger Nairobi County. Nairobi County has 319 secondary schools with 2,359 teachers. Lang'ata sub - county has a total of 205 schools, 159 of which are Primary and 46 are Secondary, of which five are public. The study was conducted in public secondary schools. The target population was five (5) public secondary schools, five (5) principals of public secondary schools, five (5) school bursars, five (5) B.O.M representatives, fifteen (15) H.O.Ds, thirty (30) teachers and two hundred (200) students' representatives giving a total of two hundred and sixty (260). The study was limited to the budget and how its management affects the academic performance of learners. It did not look into financial audits of schools nor did it seek to establish the strengths and weaknesses in financial management of any institution.

\subsection{Theoretical Framework}

According to Abend (2013), theories are formulated to explain, predict, and understand phenomena and, in many cases, to challenge and extend existing knowledge within the limits of critical bounding assumptions. The theoretical framework on the other hand, is the structure that can hold or support a theory of a research study. The theoretical framework introduces and describes the theory that explains why the research problem under study exists. Financial resource management is a key function of the leader of the institution.

In reaction to the trait leadership theory, the behavioural theories are offering a new perspective, one that focuses on the behaviours of the leaders as opposed to their mental, physical or social characteristics. Behavioural theories of leadership are based on the belief that great leaders are made, not born. This implies that people can learn to become leaders through training and observation. Naylor, (1999) notes that interest in the behaviour of leaders has been stimulated by a systematic comparison of autocratic and democratic leadership styles. It has been observed that groups under these types of leadership perform differently:

The behavioural theories first divided leaders in two categories. Those that were concerned with the tasks and those concerned with the people. Behavioural theories focus on how leaders behave. For instance, do leaders dictate what needs to be done and expect cooperation? Or do they involve their teams in decisionmaking to encourage acceptance and support? Studies have shown that effective financial resource management is directly linked to the behaviour of the leaders. Where there is team involvement in decision making process, the results are impressive as opposed to dictatorship model whereby the leader issues instructions and expects cooperation.

The study was premised on behavioural leadership theory propounded by Kurt Lewin in the 1930's which emphasizes that people can learn to become leaders through training and observation. In the 1930s, Kurt Lewin developed a framework based on a leader's behaviour. He argued that there are three types of leaders:

Autocratic leaders make decisions without consulting their teams. This style of leadership is considered appropriate when decisions need to be made quickly, when there's no need for input, and when team agreement isn't necessary for a successful outcome.

Democratic leaders allow the team to provide input before making a decision, although the degree of input can vary from leader to leader. This style is important when team agreement matters, but it can be difficult to manage when there are lots of different perspectives and ideas.

Laissez-faire leaders don't interfere; they allow people within the team to make many of the decisions. This works well when the team is highly capable, is motivated, and doesn't need close supervision. However, this behaviour can arise because the leader is lazy or distracted; and this is where this style of leadership can fail. 
Delno (2006) holds that a good leader is someone who is in control, gives direction and guidance, is an excellent listener and has good management skills. However, it is important to note at this point that leadership has been, for a long time, associated with images of powerful, dynamic persons who command respect, direct cooperate empires or shape the course of humanity.

Naylor (1999) holds that effective leadership is a product of the heart and an effective leader must be visionary, passionate, creative, flexible, inspiring, innovative, courageous, imaginative, experimental, and initiates change. Therefore, for one to be a good leader, he/she must have the following qualities: Listener, effective, ability, direction, extraordinary and responsibility (LEADER). A school head is by all means a leader, hence it is necessary for him/her to possess such qualities.

Leadership is very important for the future of humanity. Delno (2006) says that this implies that good leadership will be arrived at by the integrity of the participant and by the willingness of the individuals to work together and be inspired by a larger vision. He further notes that we all have a leader within us, and sooner or later it will awaken. In this study we seek the effectiveness of leadership in terms of financial resource management and how it impacts on the overall outcome of the school and the academic performance of students in particular. Although focus is given to the school head who is the leader, tangible positive outcome is realized through team work and collaboration.

\subsubsection{The Strengths of the Theory}

In 1945, Ohio State University conducted a series of studies to identify observable behaviours of leaders rather than focusing on their personal traits. The research came up with two main characteristics of leadership which could either be low, high or dependant on each other. The findings from Ohio State Leadership Studies suggest that effective leaders possess a strong ability to work with others and build a cohesive team which is balanced, with the capability to create structures within which activities can be accomplished.

Similarly, Kremer, Flower, Huang, and Vaughn, (2016) conducted a study on behaviour problems and children's academic achievement. They found out that the relationship between behaviour and achievements suggest that school administrators and professionals should consider providing intervention in both internal and external behavioural domains to the same students. One possible way to do this is by combining positive behavioural interventions and supports in schools.

Furthermore, teacher's emotional support moderates the relationship between temperament and academic outcomes. Training can therefore be provided to foster teachers' emotional support. For example, Strengthening Emotional Support Services is a curriculum designed to equip teachers with behavioural management strategies and minimize classroom disruption, and has been found to increase academic engagement for students with behavioural and emotional disorders. These finding bring to perspective the idea that timely provision of teaching and learning materials and a good school environment contribute to the emotional development of both teachers and learners hence leading significantly to excellence in academic performance.

\subsubsection{The Weaknesses of the Theory}

The behavioural theory became dominant in the 1950s and 1960s. Many researchers considered it a big leap from the trait theory. However, it had some limitations for no specific leadership style is suited for all circumstances. The proponents of contingency theory for instance argue that there is no single way of leading and that every leadership style should be based on certain situations, which signifies that there are certain people who perform at the maximum level in certain places; but at minimal performance when taken out of their element. According to Lamb (2013), contingency theory states that effective leadership depends on the degree of fit between a leader's qualities and leadership style and that demanded by a specific situation. 
While behavioural theories may help school heads to develop particular leadership behaviours, they provide little guidance as to what constitutes effective leadership in different situations. Charry, (2012) suggests that there is no leadership style best in all situations. Leadership researchers White and Hodgson suggest that truly effective leadership is not just about the qualities of the leader, it is about striking the right balance between behaviours, needs, and context. Good leaders are able to assess the needs of their followers, take stock of the situation, and then adjust their behaviours accordingly. Success depends on a number of variables including the leadership style, qualities of the followers and aspects of the situation and not limited to the behaviour of the leader.

Pinkerton (2003) suggests that the role of the resource manager is seen central to the process of resource management but it should not be regarded as one man task since it requires other individuals and their competencies and who are dedicated to achieving the particular objectives. Bearing in mind that these weaknesses can affect the study findings, I will interview as many stakeholders as possible, prepare and use objective instruments and seek opinions of experts in the study area.

\subsubsection{Application of the Theory to the Study}

The study was anchored on the behavioural leadership theory by Kurl Lewin which emphasizes that people can learn to become leaders through training and observation. Quality leadership is one of the concerns of every administrator. In this context, how school principals behave in the course of carrying out their duties affects the performance of their institutions. They deal directly with stakeholders from various socio-economic backgrounds hence the need to be well equipped with adequate skills. For instance, some parents are faced with financial difficulties which may lead them to withdraw their children from school prematurely. It takes proper approach and moral support from the school administration to assist such students to complete their studies. The government of Kenya introduced free secondary education for all (RoK, 2008), an opportunity which if well utilized, will in the long term ensure high retention and completion rates.

This theory is therefore relevant to the study because school administrators need financial resource management skills and right attitude in order to stimulate their teams to greater performance and success. Researchers have realized, though, that many of these leadership behaviours are appropriate at different times. The best leaders are those who can use many different behavioural styles, and choose the right style for each situation. The theory was therefore employed to examine how the style of managing available financial resources in public secondary schools influence either the good or poor academic performance of students in Lang'ata sub- County.

\subsection{Conceptual Framework}

According to Business Dictionary (2019), conceptual framework refers to a theoretical structure of assumptions, principles, and rules that holds together the ideas comprising a broad concept. A conceptual framework is an analytical tool with several variations and contexts. It can be applied in different categories of work where an overall picture is needed. It is used to make conceptual distinctions and organize ideas. Strong conceptual frameworks capture something real and do this in a way that is easy to remember and apply. Economists use the conceptual framework of supply and demand to distinguish between the behaviour and incentive systems of firms and consumers (Colander David, 2013).

A conceptual framework also refers to the diagrammatic representation that defines how study variables relate to each other. Figure 1 below shows the conceptual framework for this study, depicting the potential relationship between financial resource management as an independent variable and students' academic performance as a dependant variable. The schools under study are public entities which operate using public funds, hence the need to abide by the laid down stipulations.

Figure 1: Conceptual framework model 


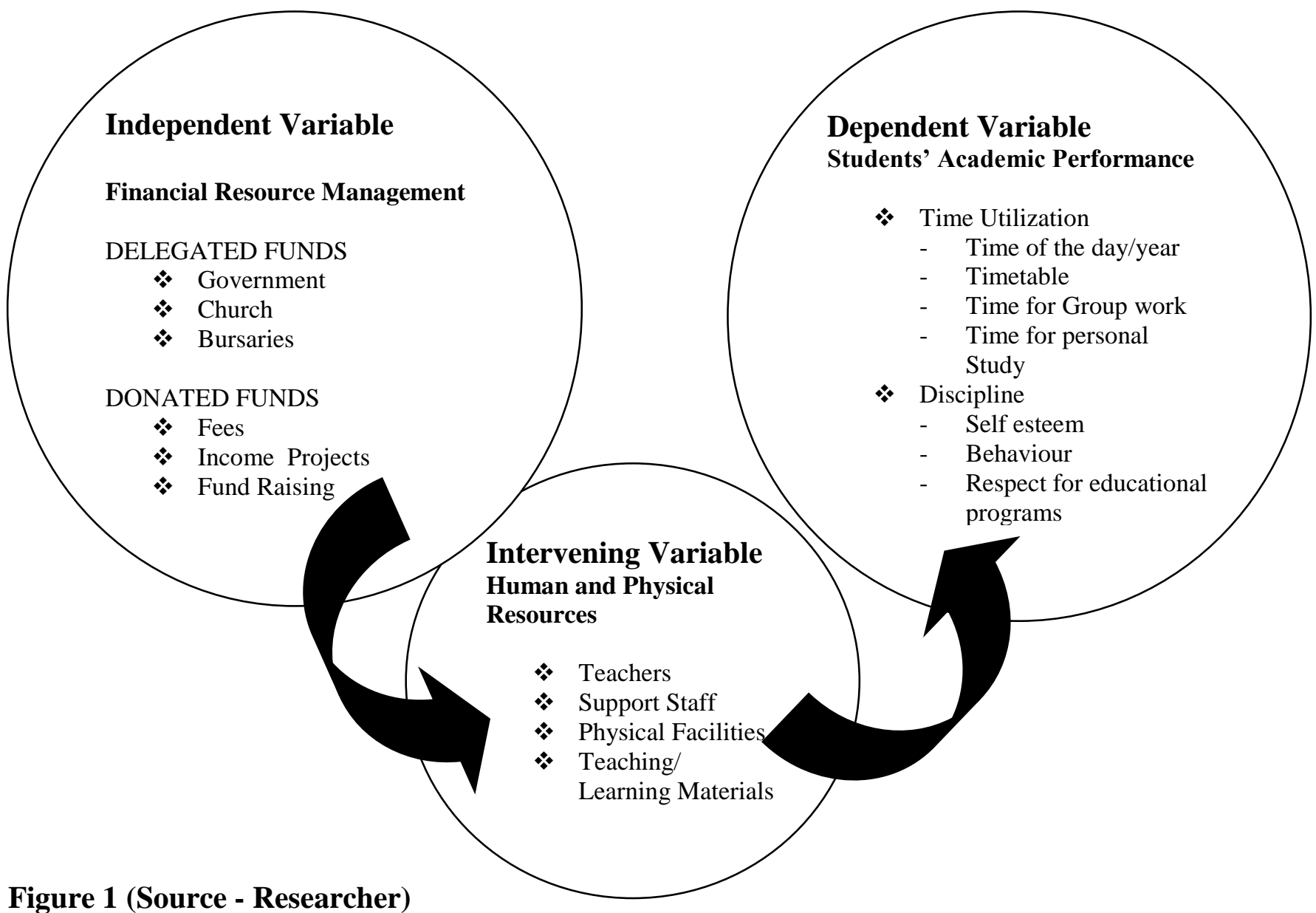

This study was based on the four components of the school system, that is, financial resources, human and physical resources, teaching and learning process and time utilization. The independent variable, which is financial resources input, is converted into human (intervening variables) by the budgeting mechanism and further into the resource hours/time (dependent variable). The arrangements of these three variables give feedback which is reflected in the students' academic performance both internally and in national examinations.

\subsection{Operational Definitions of Key Terms}

Academic Performance: Includes all factors related to the achievement of students' academic skills such as class participation, class assignments, tests, examinations and participation in extra curricula activities.

Financial Resource Management: Is a control system that determines how to use the available financial resources optimally to produce quality results often seen in the students' performance in exams, both internally and nationally.

Financial: Involves defining the goals, and developing programs that will convert such goals into monetary values.

Laissez - Faire: The leader doesn't interfere; they allow people within the team to make many of the decisions.

Lang'ata: The name of the geographical location of the study area 
Leader: Listener, effective, ability, direction, extraordinary and responsibility.

Management: Is the efficient and effective deployment of an organization's resources when they are needed, and are very critical to enhanced academic performance in schools

Resources: Something such as money, workers, or equipment than can be used to help an institution to achieve its objectives.

Student: A person who is studying at a school, especially at secondary school level.

Sub-County: A decentralized unit through which the county government provides functions and services 


\section{Review Of Related Literature \\ 2.1 Introduction}

This chapter highlights and assesses the available data on financial resource management and students' academic performance in public secondary schools. The literature is sourced from books, journals, academic papers, unpublished thesis/dissertations, and from the internet. The chapter is also an acknowledgement of the work already done by other researchers on the same study area.

\subsection{Review of Related Theories}

In this section, two theories that are important to the study are presented. Educational institutions require money in order to run their affairs smoothly. This implies that the available financial resources greatly influence the overall outcome at the end of the school cycle. The theories discussed are relative to the study variables namely resource management and students' academic performance.

\subsubsection{Behavioural Leadership Theory}

The study was premised on behavioural leadership theory propounded by Kurt Lewin in the 1930's which emphasizes that people can learn to become leaders through training and observation. In the 1930s, Kurt Lewin developed a framework based on a leader's behaviour. He argued that there are three types of leaders:

Autocratic leaders make decisions without consulting their teams. This style of leadership is considered appropriate when decisions need to be made quickly, when there's no need for input, and when team agreement isn't necessary for a successful outcome.

Democratic leaders allow the team to provide input before making a decision, although the degree of input can vary from leader to leader. This style is important when team agreement matters, but it can be difficult to manage when there are lots of different perspectives and ideas.

Laissez-faire leaders don't interfere; they allow people within the team to make many of the decisions. This works well when the team is highly capable, is motivated, and doesn't need close supervision. However, this behaviour can arise because the leader is lazy or distracted; and this is where this style of leadership can fail.

Delno (2006) holds that a good leader is someone who is in control, gives direction and guidance, is an excellent listener and has good management skills. However, it is important to note at this point that leadership has been, for a long time, associated with images of powerful, dynamic persons who command respect, direct cooperate empires or shape the course of humanity.

Naylor (1999) holds that effective leadership is a product of the heart and an effective leader must be visionary, passionate, creative, flexible, inspiring, innovative, courageous, imaginative, experimental, and initiates change. Therefore, for one to be a good leader, he/she must have the following qualities: Listener, effective, ability, direction, extraordinary and responsibility (LEADER). A school head is by all means a leader, hence it is necessary for him/her to possess such qualities.

Leadership is very important for the future of humanity. Delno (2006) says that this implies that good leadership will be arrived at by the integrity of the participant and by the willingness of the individuals to work together and be inspired by a larger vision. He further notes that we all have a leader within us, and sooner or later it will awaken. In this study we seek the effectiveness of leadership in terms of financial resource management and how it impacts on the overall outcome of the school and the academic performance of students in particular. Although focus is given to the school head who is the leader, tangible positive outcome is realized through team work and collaboration. 
The strengths of the theory were established by Ohio State University in their studies. In 1945, Ohio State University conducted a series of studies to identify observable behaviours of leaders rather than focusing on their personal traits. The research came up with two main characteristics of leadership which could either be low, high or dependant on each other. The findings from Ohio State Leadership Studies suggest that effective leaders possess a strong ability to work with others and build a cohesive team which is balanced, with the capability to create structures within which activities can be accomplished.

Similarly, Kremer, Flower, Huang, and Vaughn, (2016) conducted a study on behaviour problems and children's academic achievement. They found out that the relationship between behaviour and achievements suggest that school administrators and professionals should consider providing intervention in both internal and external behavioural domains to the same students. One possible way to do this is by combining positive behavioural interventions and supports in schools.

Furthermore, teacher's emotional support moderates the relationship between temperament and academic outcomes. Training can therefore be provided to foster teachers' emotional support. For example, Strengthening Emotional Support Services is a curriculum designed to equip teachers with behavioural management strategies and minimize classroom disruption, and has been found to increase academic engagement for students with behavioural and emotional disorders. These finding bring to perspective the idea that timely provision of teaching and learning materials and a good school environment contribute to the emotional development of both teachers and learners hence leading significantly to excellence in academic performance.

The behavioural theory became dominant in the 1950s and 1960s. Many researchers considered it a big leap from the trait theory. However, it had some limitations for no specific leadership style is suited for all circumstances. The proponents of contingency theory for instance argue that there is no single way of leading and that every leadership style should be based on certain situations, which signifies that there are certain people who perform at the maximum level in certain places; but at minimal performance when taken out of their element. According to Lamb (2013), contingency theory states that effective leadership depends on the degree of fit between a leader's qualities and leadership style and that demanded by a specific situation.

While behavioural theories may help school heads to develop particular leadership behaviours, they provide little guidance as to what constitutes effective leadership in different situations. Charry, (2012) suggests that there is no leadership style best in all situations. Leadership researchers White and Hodgson suggest that truly effective leadership is not just about the qualities of the leader, it is about striking the right balance between behaviours, needs, and context. Good leaders are able to assess the needs of their followers, take stock of the situation, and then adjust their behaviours accordingly. Success depends on a number of variables including the leadership style, qualities of the followers and aspects of the situation and not limited to the behaviour of the leader.

Pinkerton (2003) suggests that the role of the resource manager is seen central to the process of resource management but it should not be regarded as one man task since it requires other individuals and their competencies and who are dedicated to achieving the particular objectives. Bearing in mind that these weaknesses can affect the study findings, I will interview as many stakeholders as possible, prepare and use objective instruments and seek opinions of experts in the study area.

Clearly, how leaders behave affects their performance. This theory is relevant to the study because school administrators need financial resource management knowledge, skills and above all attitude in order to stimulate their teams to greater performance and success. Researchers have realized, though, that many of these leadership behaviours are appropriate at different times. The best leaders are those who can use many different behavioural styles, and choose the right style for each situation. The theory will therefore be 
employed to examine how the style of managing available financial resources in public secondary schools inform either the good or poor academic performance of students in Lang'ata sub- County.

\subsubsection{The Bucket Theory of Financial Management Practices}

This theory was developed by Dr. Barbara Rowe, with Kay W. Hansen and Marsha M. Peterson in 1990. The Bucket theory of Financial Management is an approach to planning a family's financial future. Through this theory families are able to set and reach their financial goals and also build a sound financial foundation. They suggest that for one to become financially stable is a very attainable goal. One can achieve it through systematic use of common sense approach. According to Rowe Kay and Marsha, Bucket Theory talks about five buckets hanging in stair step fashion, each below and a little to the right of the one above it. As water flows into the top bucket the bucket begins to fill. When it reaches its capacity, the water flows over the edge and into the second bucket. The process continues until all the buckets are filled.

The assumption is that the five buckets represent basic financial needs and priorities. The first one being basic needs such as food, shelter and clothing and investment of surplus finances. The water that flows from bucket to bucket represents the resources that are owned by the families. To build a sound financial base for a family, each bucket must be filled before resources are diverted to the next one. This "bucket theory" of financial management is a common sense approach to planning a family's financial future, (Rowe et al, 1990). This theory is relevant to this study since schools can use it when planning for their financial resources moving from basic needs including food, teaching/learning materials such as text books, laboratory equipment, and stationeries to other needs like investing in infrastructure.

\subsection{Review of Empirical and Conceptual Literature}

In this section, literature is reviewed based on the studies done by other scholars on the financial resource management and its influence on the students' academic performance in public secondary schools.

\subsubsection{Influence of budget management on students' academic performance in public secondary schools in Langata sub-county, Nairobi County.}

Hemsing and Baker (2013) in their study on the effects of tight budgetary control on managerial behaviour in the Swedish public sector noted that managers in the municipalities and universities experienced tight budgetary controls. As such, managers were less committed to their organization. The study however did not explicitly explain how budgetary control and management influenced management of funds at universities and municipalities. The study targeted managers from different municipalities and universities throughout Sweden.

Kapur (2018) studied Factors Influencing the Student's Academic Performance in Secondary Schools in India: University of Delhi. He suggests that the major determinants of academic performance include class participation, class assignments, tests, examinations and participation in extra curricula activities. Furthermore, pressure on the teachers and administrators from stakeholders to improve academic performance has enabled schools to come up with advanced strategies. Some of the strategies include effective teaching and learning methods, use of technology, promoting extra coaching, and rewarding students for good performance.

Ahmed, Babar and Kashif, (2010) conducted a study on the effect of financial management practices on organizational performance. The authors sought to establish the relationship between organizational performance and financial management practices among listed companies in Pakistan. Financial management practices that featured were working capital management, capital structure decisions, dividend policy among others. The finance executives and financial analysts were targeted. The study concluded that financial management practices positively influenced organizational performance among the surveyed companies. 
School financial management strategies and skills reflect the level of outcome in terms of students' academic performance. Birimana and Orodho (2014), in their study conducted in Huye District - Rwanda, established that there is a positive and significant correlation between effective management of teaching and learning resources and teacher efficient classroom management, content delivery and eventual students' academic performance. They argue that resource management strategy is the efficient and effective deployment of an organization's resources when they are needed, and are very critical to enhanced academic performance in schools. Such resources may include financial resources, inventory, human skills, production resources, or information technology. It consists of analysis, decisions, and actions an organization undertakes in order to create and sustain competitive advantages (Birimana \& Orodho, 2014).

In another study, Coleman and Anderson (2000) examined decentralization and education service delivery in North Shewa region of Ethiopia. The authors noted that the school heads and finance committees ought to pay attention to basic budgeting tasks such as accounting procedures that reflect the true financial position of the school as well as internal and external controls and safety mechanisms that safeguard data from alterations and loss in line with the finance policy.

Bua and Adzongo (2014) conducted a study in Zone A Senatorial District of Benue State, Nigeria to investigate the impact of financial management on secondary schools administration. The study concluded that prompt payment of staff salaries and allowances had significant impact on the management and performance of secondary schools. Furthermore, the researchers established that school fees and other generated revenues had significant impact on the provision of instructional materials.

Hansraj (2007) conducted a study to investigate the role of principals in financial management in South Durban in South Africa. The study noted that the school principals and school governing bodies had the responsibility of ensuring that financial resources were well utilized for the optimum performance of all sectors including academics. The study emphasized prudent financial management though adequate budgeting, transparency in procurement and purchases, accountability and adequate allocation of the available resources in order to enhance the achievement of the set objectives.

Miriti and Wangui (2014) studied financial management in the context of training needs of public secondary school principals in Machakos County. The study intended to suggest areas for development of effective training programs for principals in order to enhance prudent financial management of resources. The target population was 16 principals from public secondary in Masinga Sub-County. It was noted that financial management remained a challenge for most of the surveyed schools. Moreover, training programs on financial management were ineffective. The study recommended that effective financial management training programs should be developed based on the needs.

In response to the need for improved performance in the education sector, Nairobi County, in its Strategic plan (2014), emphasized prudence in finance and resource management. The Finance and Economic Planning Department of Nairobi County has a vision to be a leading sector in public policy formulation, implementation, coordination, supervision and prudent resource management. The sector mission is to provide overall leadership and policy direction in resource mobilization, management and accountability for quality public service delivery. (Nairobi County Integrated Development Plan, 2014). This Development plan, in conjunction with the Kenya Vision 2030 emphasized development and improvement of the community by providing essential services to the public through a strong, efficient and result oriented public sector policy. It is expected that when all sectors, especially in education, work efficiently, then students' academic performance steadily improves.

These scholars allude to the fact that all students have equal chances to perform well in exams despite their conditions or stations in life. Each country allocates considerable resources to education at all levels and follows up to ensure quality deliverance and sustainable output. Despite the efforts, performances in schools differ. 
Asemah (2010) argues that financial management in schools implies the identification of the sources of school finance, fund raising, methods of funds collection, and effective application of revenues to the school system in order to achieve the stated goals and objectives. From the above literature reviewed, it is apparent that public secondary schools in Lang'ata sub-county are still experiencing insufficient resources hence leading to inadequate performance. This study addressed some of these pertinent issues with the aim of establishing the relationship of financial resource management and students' academic performance in public secondary schools.

\subsubsection{Influence of financial controls on the students' academic performance in public Secondary Schools in Langata sub-county, Nairobi County.}

Measuring the extent to which financial resource controls affect students' academic performance in public secondary schools involve various factors including access, retention and rate of completion. Lewin (2014) in his study on financing education in Asia: profiling participation and financing towards 2030, noted that in Asia, most countries now enroll almost all children in school, with the majority completing the first cycle of basic education. Asia is geographically diverse, comprising of larger countries such as India, low income countries like Bangladesh and Pakistan as well as some of the smallest and wealthy countries like Singapore and Brunei. The study concluded that the development of the Pacific Rim Asian countries in the latter part of the 20th century was the result of sustained investment in education focused on learned capabilities and cognitive competencies. The researcher further noted that future financing of education in Asia should build on this foundation and extend the benefits of mass access to education to the populations that are still marginalized, and ensure that future expansion is pro-poor and makes use of the latent talents of all citizens in ways that are efficient, effective and equitable.

In England, Rosalid and Downs (2004) noted that a few members of the governing committee showed interest in the technical details of school financial management reports presented to them while most school board members are unable to learn about the school financial values and processes due to limited knowledge or lack of time to dedicate to these matters. Such an approach affects the overall performance of the school, especially the students' academic performance. Another study conducted by Keith (2008) in the UK on Effect of Government Bursary on Transition and Completion rates found out that such subsidies led to high transition and completion rates.

Hemsing and Baker (2013) investigated the effects of budgetary control on managerial behaviour in the Swedish public sector. The target population were managers from various municipalities and universities throughout Sweden. The study noted that managers in the municipalities and universities experienced tight budgetary controls. Apart from improving efficiency, this trend ensured that the institutions met their obligations hence leading to better performance in all sectors.

Walela (2015) in his study noted that managers of secondary schools in order for them to manage their finances well ought to look ahead, establish priorities and plan the activities in the school. He observed that effective school financial management is brought about by clear long term plans and priorities. It is important that clear plans for spending the limited funds are drawn. Therefore, it is expected that for this study, budget participation would enhance the financial management of the schools. Ogunshola and Adewale (2012) on the other hand, found that there is a close relationship between parent's occupation and children's academic outcome. Parents with relatively high incomes are likely to support their children's education hence motivating them to achieve better grades in school. A study done by Lewin (2008) on Financing Education in Mauritius, explained that educational subsidies make secondary education more accessible, improve retention and completion rates and empower the learners to perform well in their studies.

Studies have shown that financial resource management play a key role in the achievement of the intended school goals and objectives. In Zimbabwe for instance, Chatiza (2011) investigated the basic management and financial skills by school development committees. The researcher noted that school heads 
in Mashonaland East province have had cases of mismanagement of funds and abuse of the incentives meant for teachers. This adversely affects the overall performance in schools, especially the students' academics. A similar study conducted by Wushe, Ndlovu and Shenje (2014) concluded that for proper utilization of the school's resources, there is need for collaboration among the various stakeholders such as the principals, school development committees and the community.

In Kenya, the government subsidizes education through bursaries and full payment of tuition fees in public secondary schools in line with one hundred per cent transition policy. In 2015, a study by Muthoki (2015) in Mtito-Andei Division, Kibwezi sub-county, Makueni County found out that government subsidies helped students to access secondary education, improved retention, completion, and subsequently led to high academic performance. Another study conducted by Onuko (2012) on the impact of bursary schemes in Gem, Siaya County found out that there were high retention rates in day secondary schools. Through the devolved system, the County Bursary Fund, under the County Ministry of Education and Youth Affairs assist students to access and remain in school hence leading to better academic performance at the end of the four year cycle.

A study conducted by Mwanzia (2013) sought to ascertain the effect of corporate governance of financial management of Constituency Development Fund (CDF) in Kenya. The study focused on Nairobi County. Descriptive survey design was used in the study. A sample of 120 CDF members was obtained. The study found out that governance enhances proper management of funds. It was further noted that budget, internal controls and financial reporting enhance financial management of the CDF funds in Nairobi County. The researcher recommended that CDF ought to improve the budgeting practices in order to further improve financial management.

Junge, Bosire and Kamau (2014) in their study analysed the effect of budgetary practices on performance of public secondary schools in Nakuru municipality. The 22 public secondary schools in the municipality were targeted. The study noted that budget practices such as budget control and allocation positively influenced performance of the schools. It was also noted that budget allocation and annual budget planning were important aspects that improved financial management in organizations in the public sector.

Fundraising has traditionally been an activity that many parent groups have undertaken very successfully over the years and have raised a lot to support their children's schools. In their discussions of the school development plan, the Board of Management may identify particular items or activities that would benefit from additional funding. There may be discussions about what the priorities are and these can then be shared with parents. Once targets are set, it may be effective to form a fundraising sub-committee. Some parents will have particular talents in that area and it may be a way of involving a wider group of parents to help with specific activities.

A Study conducted by Njau (2013) on the Effect of Secondary Education Bursary Fund on Access and Retention of Students in Public Secondary Schools in Juja Constituency, Kiambu County Kenya found out that Secondary Education Bursary has led to high retention and completion rates in day secondary schools. The researcher observed that following the changes in the allocation mechanisms since 2003, claims of misallocation of funds, double awards to one student in two schools, awards to students not enrolled in any school, as well as excessive patronage by members of parliament were minimal hence a significant improvement in the management of bursary to needy students in public schools.

The internal resource control of an organization is to ensure efficiency, effectiveness of activities, reliability of information, compliance with applicable laws and timeliness of financial reports (Jokipii 2009 and Changahit et al, 2001). Proper internal resource control system ensures that the school principal would utilize the financial recourses in a way that will safeguard the interest of the donors and contributors. According to Jajo (2005), controls in general involve authorization, segregation of duties, record keeping, safeguarding and reconciliation. Paisely (1992, observed that the survival of an organization depends on 
effective financial control. He further noted that managers should adopt rules and regulations so as to prevent fraud, anticipated overspending and have a continuous and accurate knowledge of the overall financial position.

Mobegi et al (2012), in his study noted that more than 58\% of BOG chairpersons, principals, HOD's and Bursars/accounts clerks who were involved in the study concluded that weak internal control mechanisms were the major factors contributing to financial mismanagements. This was evidenced by the fact that at the time of the study, receipting of school money had a problem because fee registers were missing; schools had no trained storekeepers and school property was kept in deputy head teacher's offices. The researchers concluded that all these situations led to loopholes for mismanaging school finances. Therefore to have a successful learning institution requires proper accounting records and appropriate management control system. However, despite the efforts in managerial skills as evidenced by the reviewed literature, there are still grey areas in terms of resource allocation and utilization for the improvement of students' academic performance which this study attempted to address.

\subsubsection{Challenges Principals of Public secondary schools face in the management of finances}

The resources of public institutions are managed under legal frameworks. Legal mandates that guide the acquisition and use of public financial resources are stipulated in binding documents, the interpretations of which sometimes pose challenges to school administrators. In this section, we review some of these legislations and relate to how they pose challenges to school principals in terms of financial management. School finances are guided by legal frameworks established through legislations in individual countries. Such frameworks give legal authority to the principals and the Board of Management to carry out their mandate. Legal authority refers to legal power vested on education administrators to take decisions which must be obeyed because it has legal implications.

Bolman and Deal, (1991) define authorities as the people who are entitled to make binding decisions. School administrators have various sources of legal mandate to exercise their authority such as Acts of Parliament, National Constitution, International Laws, Judicial Laws, African Statutory Laws, Policies, Kenya Basic Education Act 2013, Teachers Service Commission Act, Architect's Act, Public Health Act among others. Legal authority can therefore broadly be defined as any published source of law that presents the legal rules, legal doctrines, or legal reasoning that may be used as the basis for legal decisions including decisions on financial matters. Examples of legal authority for school administrators on financial management include:

In order to understand the education policies posing challenges to school principals in terms of financial resource management, it is proper to have a brief recourse to the constitution on which such policies are anchored. The Constitution is a body of laws which defines the role, powers and structure of different entities within a state such as the executive, legislature (parliament), and the judiciary. It also defines the basic rights of citizens and the relationship between the Central Government, State, Provincial or Territorial governments. (Wango, 2011). The Constitution protects the individual freedom, describes the rights and duties of the citizens and protects the fundamental principles governing the country.

The Kenyan Constitution (2010) for example, states that every person has the right to education (Article 43: 1f). It further stipulates that every child has the right to free and compulsory education. (Article 53:1b). Article 53.1d states that every child has the right to be protected from abuse, neglect, harmful cultural practices, all forms of violence, inhuman treatment and punishment, and hazardous or exploitative labour. A person with any disability is entitled to access educational institutions and facilities for persons with disabilities that are integrated into the society to the extent compatible with the interests of the person. (International Right to Education Project, 2014). Article 55: The state shall put in place affirmative action programs to ensure that the youth access relevant education and training. Article 56: Minorities and marginalized groups are provided special opportunities in education. Article 337: Establishment of Teachers Service Commission (TSC). Article 27: Guarantees equality and freedom from discrimination. 
School administrators work within countries or territories with laws that govern life, activities or businesses. They should therefore be aware of the Constitution especially in areas dealing with educational financial management.

Education is further guided by policies, especially in financial resources, which sometimes pose challenges to administrators. Policies are deliberate system of principles to guide decisions and achieve rational outcomes. It is a statement of intent and is implemented as a procedure or protocol. Therefore education policy consists of the principles and government policies in education sphere as well as the collection of laws and rules that govern the operation of education systems, such as public finance management systems. Education policy is understood as past or up to date statements or series of statements which explain, recommend or exclude a course of action or actions to be taken to run the system of education. Examples include Universal Free Primary Education Plolicy (UFPE).

Globally, education managers are faced with challenges of change which are happening at a fast pace due to advancement in technology. The challenges are bound to test the abilities of education managers than people at any other level. (Gathira, 2008) notes that education managers of yester years had to deal with some change but change was not at a rapid pace, scope or range as evident in more recent years. For instance, the post-apartheid school funding policies of South Africa view every school as a cost centre where each public school principal, as a responsible manager, is expected to accept accountability for the investment that the state makes in his or her school. A study by Mpolekeng (2011) on the effectiveness of financial management in schools in the Lejweleputswa education district, South Africa revolved around principals embracing their role of responsibility managers, assisted and supported by their school governing bodies, tasked with leading their schools towards self-reliance.

In Kenya, Universal Free Primary Education was first launched in 1971 by President Jomo Kenyatta then reintroduced in 2003 by the Rainbow Coalition Government under President Mwai Kibaki.; Free Secondary Education policy introduced in 2008; Bursary for needy students; health policy among others. For efficient management of school finances, the school administrators should be aware of these policies and apply them in their daily strategies. Universal Free Primary Education Policy and One Hundred Per cent Transition Policy imply higher enrolment in public secondary schools. This comes with higher demands on infrastructure and recurrent expenditure. Sometimes the allocated resources and funds are inadequate to run the schools hence posing challenges to the principals.

Githaka and Cheloti (2017) studied the influence of government bursaries on the Free Day Secondary Education Policy. The aim of the study was to investigate the influence of Government Bursaries on completion rates in public day secondary schools in Kitui County, Kenya. The researchers noted that bursary funds for secondary schools are channelled through the Constituency Bursary Fund. This fund is meant to supplement the effort of Free Day Secondary Education to meet the financing gap of needy students. The fund was initially operated through the Ministry of Education and operationalized by the school Board of Management (BOM) at school level as Secondary Education Bursary Fund (SEBF) (MoE, 2008). Provision of bursary is one of several strategies used by government to ensure that disadvantaged children have equal opportunity in accessing education at all levels. This has led to high completion rates among the disadvantaged children (RoK, 2008). However, principals face the challenges of delayed disbursement of funds, hence slowing down school operations which in the long run affect performance.

Atieno, E. (2012) in her study on the Challenges faced by Newly Research and Publication Appointed Principals in The Management of Public Secondary Schools in Bondo sub-county, observed that head teachers have many challenges when it comes to financial management. The researcher recommended that principals should be trained on financial management as a way of building their capacities. 
Another study conducted by Magak (2013) Kisumu East, Kenya on the challenges faced by school heads in managing institution funds established that gaps in the management of finances was due to inadequate auditing knowledge by the school heads, lack of internal auditing and irregular supervision by the sub-county personnel. The study recommended that government policy on auditing of school books should be revised in order to further enhance control and management of school funds.

Studies have shown that challenges faced by school principals in the management of financial and other resources have been given attention through various legislations, policies, moral as well as material support. However, there are still some challenges faced by principals in the management of the available resources which adversely affect the academic performance of students. These challenges, as shown from the reviewed literature, range from the process of acquisition of resources, allocation, supervision and proper utilization in line with the set goals and objectives. This study attempted to address some of these challenges and to give valuable recommendations.

\subsubsection{Strategies, with regard to financial resource management, used by Principals of Public secondary schools in Lang'ata sub-county to improve academic performance}

School managers are constantly exploring ways to better educate students and improve school performance. School-based management system offers a way to promote improvement by decentralizing control from central county offices to individual schools. It attempts to give school administrators, teachers, parents and other community members more control over what happens in the schools. This makes management of financial resources more appropriate in the rapidly changing environment.

Financial management requires accountability by those in management. The World Bank (2001) in its world development report proposed that there is need to improve public management systems to make programs more efficient and accountable. With the resources being scarce compared to the numerous wants and needs, any misuse of these resources may bring about wastage. Economic use of the available school funds ensures proper maintenance of equipment, diligent expenditure, prudent tendering and prioritizing the needs.

A study conducted by Amirize and Ololube, (2018) on Principals Fund Management Strategies for Effective Administration of Public Secondary Schools in Rivers State, Nigeria found out that there are significant relationships between principals fund management strategies and effective administration of secondary schools in Rivers State. This implies that with proper resource managerial skills, principals can stimulate their teams to perform well hence leading to an improvement in the academic achievements of the students.

Mbogi (2012), in his study found out that ignorant BOM was one of the factors contributing to financial mismanagement in public schools. He stated that majority of BOM were illiterate and not conversant with accounting procedures. The study also showed that selection of board members was predetermined by the area member of parliament who chose people of their own interest. In a school where the BOM is not stable, the overall performance tends to be below average.

Similarly, Wamae (2008) did a study on challenges of budgeting at NSSF. The aim of the study was to establish the challenges of budgeting process and the challenges faced when drawing up a budget to be used by an organization and how organization can effectively face the budgeting challenges. The population constituted nine (9) boards of directors and sixteen (16) senior managers at NSSF who were concerned with budgeting issues at the organization. The researcher collected data by use of questionnaire, observation and interviews as main instrument of data collection.

However, Deventer and Kruger (2003) observe that the characteristic of such an approach to education management in general and financial management in particular, is the emphasis on transparency and information sharing among all stakeholders. For the school principal and Board of Management, this 
means that they must deal with funds in a responsible manner and that they are accountable to the parents, the learners, the community and all stakeholders. Deventer and Kruger (2003) further mention that to be able to provide a clear picture of the state of the school's finances, the principal should see to it that monthly and quarterly statements are kept.

Financial management is a very important aspect of management in any organization especially in a school. It embraces all accounting techniques that assist to provide information designed to help management in planning and controlling the activities of the school. According to Aringo (1987), education administrators need to be regularly informed of any new management techniques and changes that will make the program worthwhile. This implies that principals need to update their techniques of planning, organizing, controlling and directing human, financial and material resources for the achievement of the goals set.

Bisschoff and Mestry (2007) in a study on financial school management carried out in Cape Town, South Africa, suggest that for a school to function economically, the school financial committee through the Board of Management should be knowledgeable about: School balance sheets; the money that is needed and why it is needed; how and where to get the money needed; how the money will be spent; all the relevant legislations on public financial management; guidelines such as departmental circulars; the purpose of a budget; the necessity of policymaking; setting up of necessary structures e.g. Finance Committee, to take charge of finances; understanding and monitoring of dates important for different processes and putting monitoring mechanisms in place and reporting to parents.

A similar position is held by Khumalo (2001) who argues that all decisions made by financial managers have financial implications and therefore the financial manager or the principal as the accounting officer has to consider whether the decisions made are realistic with regard to the size of a school. At the same time, progress or improvement should not be delayed by budget problems.

Bisschoff and Mestry (2007) further observe that a finance committee should be formed to assist the Board of Management in financial matters of the school. Where members of the Board of Management have no or little financial knowledge, they should ask for the services of an expert with sound financial knowledge from the Parents Association. It is important for the finance committee to conduct regular meetings to discuss financial matters and its members must be committed to carrying out their responsibilities. The finance committee may consist of the treasurer, principal, educators, parents and nonteaching staff. The treasurer must keep accurate records of all transactions and prepare documents for the auditors.

Financial information is communicated in the form of short term and long term financial statements. The reports indicate the school's revenue and expenditure. Goniwe (2005) portrays guidelines on the handling of cash and petty cash. Schools must have an agreed policy for handling the receipt of cash payments. There must be a person responsible and a system for issuing receipts/controlling the money. Security for the handling and banking of money must be in place and monitored. Schools should keep a small amount of money in cash to pay for cash expenditures, that is, travel, cash purchases among others. A certain amount of cash is kept at the school in a safe place and is used to pay for accounts that are too small for cheque or internet payments.

Other studies give further insight in understanding the relationship between financial resource management and performance in institutions, especially in schools. Muleri (2001) did a study on budgeting practices in NGO in Kenya. The aim of the study was to establish effectiveness of budgeting practices among British NGOs in Kenya. The researcher looked at the concept from a different point of view and found that most organizations used modern practices as zero based and philosophies to reduce financial mismanagement. The researcher observed that there is a limitation on budgeting process which leads to cost cutting in order to achieve cost effectiveness, there is lack of solid base to enforce budgetary controls as a 
motivator and concluded that although profit was the main indicator of performance in public sector, budget management should be measured against the background of sound financial policies. The researcher concluded that budgeting is well accepted in evaluation and generally used to communicate plans and operations.

From the study the researcher found that that the organization faced challenges when drawing up a budget and the biggest challenge was on commitment. Various heads of department did not take budget seriously leading to giving ambitious budgets which would end up not achieving target, leading to complaints from the board. The researcher concluded that budgeting was very effective at NSSF as they served their purpose by assisting in control, and used as means by which management communicates to departments.

The Researcher added that the process of budgeting at NSSF faced some challenges which were inability to achieve the required value of business, inadequate authority to spend despite allocation, cost inflation, poor participation and poor co-ordination of the exercise. The researcher recommended, that all units in the organization should be involved in budgeting and enough time be allocated to the preparation process.

Kigochi (2008) did a study on Survey of operational Budgeting Challenges, in the insurance Industry in Kenya. The study surveyed the challenges of operational budgeting system in the insurance industry in Kenya. The study sought to bring out the challenges in formulating operational budgets in the insurance industry in Kenya and to propose solutions to the major challenges. The objectives of the study were to determine the challenges faced when formulating an operational budget in the insurance industry in Kenya and also to establish the effectiveness of those operational budgets.

This study was descriptive in nature and the researcher used the survey method. The population of this study consisted of 42 currently licensed insurance companies in Kenya. Data for the study was collected using a structured questionnaire. The data collected was then analyzed with the help of Excel Spread sheets. From the findings, the researcher found that operational budgets were effective in the insurance industry as they served their purpose of forecasting the future, assisted in control, acted as a means by which management communicates to other levels of department, acted as a means of performance appraisal and also it motivated employees to do better.

The study also found that the challenges faced when formulating the operational budgets were inability to achieve the required value of new business, management of acquisition and maintenance costs, time constraints, desire for comfort budgets, lack of continuity in the committees, competence levels of budgeting teams, non-adherence to the laid down budgets by departments, lack of adequate authority to spend despite allocation, non-achievement of the main top line income earners, cost fluctuation or inflation on costs, lack or poor participation, poor coordination of the exercise, estimation of some factors was difficult and also it was expensive as a control/monitoring tool.

\subsection{Summary of literature review and identification of knowledge gaps}

The literature reviewed above shows that studies have been conducted on school financial resource management and students' academic performance. However, there are still several gaps which the review has identified and which require further research. Some of the specific gaps include examining the challenges faced by Principals of Public secondary schools in the management of finances and other resources; strategies used by Principals of Public secondary schools in Lang'ata sub-county to manage the available resources with the aim of improving academic performance; the relationship between financial resource management and students' academic performance and the extent to which financial resource management affect students' academic performance in public Secondary Schools in Lang'ata sub - county, Nairobi County. 


\section{Research Design And Methodology \\ 3.1 Introduction}

This chapter outlines the methodology that was used in the study based on locale of the study, research design, target population, sample and sampling procedures, description of research instruments such as questionnaires, interview schedules, and observation schedules, test for validity and reliability of data, data collection procedures, ethical issues and data analysis techniques.

\subsection{Locale of the Study}

This study took place in Lang'ata Sub-County, a suburb of Nairobi in Kenya. The suburb consists of many smaller housing estates. They include Nairobi Dam, Otiende, Southlands, Ngei, Jambo estate, Onyonka, Madaraka Estate, Kutch Prant, Rubia and many others. These developments are primarily mansionnettes or apartment blocks. Lang'ata lies southwest of the city's central business district, east of Karen, approximately 18 kilometers $(11 \mathrm{mi})$, by road, from the centre of Nairobi. (Globefeed.com,2015). The coordinates of Lang'ata are:1 $1^{\circ} 21^{\prime} 58.0^{\prime \prime S}, 36^{\circ} 44^{\prime} 17.0^{\prime \prime E}$ (Latitude:-1.366111; Longitude:36.738056). (Google Maps, 2015).

Lang'ata has several attractions such as the Giraffe Centre, Uhuru gardens, Bomas of Kenya, Carnivore Restaurant and Wilson Airport, the largest private airport in Kenya. Lang'ata is also name of the Lang'ata Sub - County, which covers affluent estates Karen and Lang'ata, but numerically most of its population come from Kibera, the largest slum in Kenya. Lang'ata Sub - County is subdivided into two constituencies; namely Langata and Kibera Constituencies (Globefeed.com,2015). Figure 2 - Map of Kenya: Location of Lang'ata Sub - county in Kenya (Refer to appendix I)

\subsubsection{Administrative Sub - divisions}

Lang'ata sub - county is part of the larger Nairobi County. Nairobi is divided into nine sub-counties namely; Starehe, Kamukunji, Kasarani, Makadara, Embakasi, Njiru, Dagoretti, Lang'ata and Westlands.

Table 1 List of Sub-Counties in Nairobi County

\begin{tabular}{|l|l|l|l|l|}
\hline $\begin{array}{l}\text { Table 1: } \\
\text { Area of the County } \\
\text { by Administrative } \\
\text { Units Sub-County }\end{array}$ & Area(km2) & Divisions & No. of Locations & No. of Sub-Locations \\
\hline Starehe & 10.6 & 3 & 6 & 12 \\
\hline Kamukunji & 11.7 & 3 & 9 & 18 \\
\hline Kasarani & 85.7 & 2 & 11 & 24 \\
\hline Makadara & 20.1 & 3 & 5 & 11 \\
\hline Embakasi & 52.1 & 3 & 6 & 13 \\
\hline Njiru & 156.2 & 3 & 6 & 10 \\
\hline Dagoretti & 38.7 & 3 & 8 & 16 \\
\hline Lang'ata & 223.4 & 4 & 7 & 16 \\
\hline Westlands & 97.6 & 3 & 6 & 15 \\
\hline Total & $\mathbf{6 9 6 . 1}$ & $\mathbf{2 7}$ & $\mathbf{6 4}$ & $\mathbf{1 3 5}$ \\
\hline
\end{tabular}

\section{Source: Provincial Commissioner, Nairobi, 2013}

\subsubsection{Education}

Education is key to the general development of both individuals and the country. Lang'ata sub county, the location of the biggest informal settlement in Africa, has put emphasis on education as a means of empowering its people, with the aim of poverty reduction. The education process goes through preschool, primary, secondary and tertiary levels. According to Nairobi County Integrated Development Plan, 2014, the larger Nairobi County has 2,906 ECD centres with a total of 8,470 ECD teachers. The teacher pupil ratio in the pre-primary school is 1:34 while the transition rate is 98 per cent. On Primary Education, 
the County has 1,235 primary schools with 7,741 teachers. The teacher pupil ratio is 1:55. The total enrolment is 429,280 with 207,056 boys while that of girls is 222,224 . The average years of attendance for primary school are 8 years while the retention rate is 96.4 per cent. (Nairobi County Integrated Development Plan, 2014 Pg. 30)

Similarly on Secondary Education, Nairobi County has 319 secondary schools with 2,359 teachers. The teacher pupil ratio is $1: 22$. The total enrolment is 49,728 with 26,755 boys and 22,973 girls. The retention rate is 94.6 per cent. Lang'ata sub - county has a total of 205 schools, 159 of which are Primary and 46 are Secondary. Nairobi County has two public universities - University of Nairobi and Technical University of Kenya. There are ten private universities and 16 campuses operated by both public and private universities in the County. Figure 3 shows the map of Nairobi County in which Langata sub-county is situated. (Refer to Appendix I)

\subsection{Research Design}

A research design is the set of methods and procedures used in collecting and analyzing measures of the variables specified in the research problem. After developing and explaining the research question, the next step is to figure out how to answer the question given the complex nature of reality. Research design is therefore a framework that has been created to find answers to research questions. According to Howard (2010), research design refers to the point where the researchers define the scope of the research, that is, the limits and content of the data investigated.

There are several types of quantitative research design each with its own typical characteristics and can be classified as follows: descriptive research design - for example survey, case study and natural observation; correlational research design - for example case -control study and observational study; Quasi - experimental/ causal-comparative research design - for example field experiment and Experimental research design - for example an experiment with random assignment.

The nature of any scientific inquiry is to find the truth. Human beings have long been preoccupied with the attempts to understand their environment and what it presents to them through the senses. The means to achieve this goal may be divided into three categories, thus: Faith (Belief/Traditional Method); Reasoning and Scientific Approach.

However, these means overlap in their attempt to find solutions to complex modern human problems. This work focused on the scientific research as a means of acquiring authentic knowledge. Broadly speaking, research can be classified into three main groups depending on the time when the data is collected for investigation, that is, historical research, present research (current) and futuristic research. Each group can be divided into two main types of research that is quantitative and qualitative.

Cohen (2007), defines quantitative research as social research that employs empirical methods and empirical statements. He states that an empirical statement is defined as a descriptive statement about what "is" the case in the "real world" rather than what "ought" to be the case. Typically, empirical statements are expressed in numerical terms. Another factor in quantitative research is that empirical evaluations are applied. Empirical evaluations are defined as a form that seeks to determine the degree to which a specific program or policy empirically fulfils or does not fulfill a particular standard or norm.

Moreover, Creswell (2012) has given a very concise definition of quantitative research as a type of research that is 'explaining phenomena by collecting numerical data that are analyzed using mathematically based methods, in particular statistics. Looking at this definition step by step, we may deduce the following: The first element is explaining phenomena. This is a key element of all research, be it quantitative or qualitative. When we set out to do some research, we are always looking to explain something. In education this could be questions, for example, "What is the relationship between financial resource management and students' academic performance in public Secondary Schools in Lang'ata sub - county, Nairobi County?" 
In quantitative research we collect numerical data. In order to be able to use mathematically based methods our data has to be in numerical form. This is not the case for qualitative research. Qualitative data are not usually numerical, and therefore cannot be analyzed using statistics. However, while it is important to use the right data analysis tools, it is even more important to use the right research design and data collection instruments.

Therefore, quantitative research is essentially about collecting numerical data to explain a particular phenomenon. In everyday life, we use quantitative methods to answer certain questions. For example: What is the influence of financial resource management on students' academic performance in public Secondary Schools in Lang'ata sub - county, Nairobi County? ; To what extent do controls of financial resources affect students' academic performance in public Secondary Schools in Lang'ata sub - county, Nairobi County?; What challenges do Principals of Public secondary schools face in the management of finances?; What strategies, with regard to financial resource management, are used by Principals of Public secondary schools in Lang'ata sub-county to improve academic performance?

These are all questions we can look at quantitatively, as the data we need to collect are already available to us in numerical form. However, we can develop a questionnaire that asks respondents to rate a number of statements as either disagree strongly, disagree, agree, agree strongly, and give the answers a number (e.g. 1 for disagree strongly, 5 for agree strongly). In this chapter we shall concentrate on the quantitative research designs and look at how we can develop instruments for this particular purpose. The study used a descriptive research design, the reason being it gives a broad spectrum of feedback because it involves gathering cross-sectional data from a wide range of respondents and making interrelationships between the variables.

In this study, cross-sectional survey research design was preferred. It was preferred against all others because it uses scientific sampling and questionnaire design to measure characteristics of the population with statistical precision. It seeks to provide answers to such questions as "How many people feel a certain way?" and "How often do they do certain behaviour?" Survey research enables management to make comparisons between groups. It provides estimates from a sample that can be related to the entire population with a degree of certainty. Resource management has a central place in the entire operations of the school hence data collected to assess its influence on the students' performance need to be analyzed with reliable instruments.

Descriptive survey attempts to describe and interpret what exists as present in the form of conditions, practices, processes, trends, effects, attitudes and beliefs. Survey method is convenient to point out the existing situation of financial resource management practices in public secondary schools and challenges in the wider area under the study. Although broad in scope, this study used survey research design, a form of quantitative research in which the investigator identifies the sample and the population, collects data through questionnaires or interviews, and draws conclusions or makes inferences about the population. It is a useful design to use when researchers seek to collect data quickly and economically, study attitudes and opinions, and survey geographically dispersed individuals.

There are two major types of survey designs, that is, cross-sectional and longitudinal. Cross-sectional survey designs are used to assess useful information at one point in time. Cross-sectional studies are of several types. They can: Examine current attitudes, beliefs, opinions, or practices; compare two or more educational groups in terms of attitudes, beliefs, opinions, or practices; assess community needs for educational services; be used to evaluate programs and also be used nationally to survey many participants across a large geographic area.

In this study, the researcher collected data that vary in forms such as mailed questionnaires, web-based questionnaires, one-on-one interviews, telephone interviews, and focus group interviews. He then weighed the advantages and disadvantages of each; administered well-tested instruments with good questions and scales; and sought a high response rate from participants using procedures that ensured a high return rate and 
was not biased. Therefore, it is for this reason and many other proven scientific results, as discovered in the research studies, that descriptive survey design was employed for this study.

\subsection{Target Population}

Bauer and Gaskell (2000) define population as the complete collection of items or persons who are the target of the research. The target population for this study comprised principals of 5 public secondary schools, 5 school bursars, 15 heads of departments, 30 teachers, 200 students and 5 representatives of the Boards of Management distributed in public secondary schools in Lang'ata sub-county, Nairobi County.

These respondents were used to generate data on financial resource management in public secondary schools and its influence on the students' academic performance. The unit of analysis was the bursars. The bursars were preferred because they deal with day to day financial transactions of the school. Lang'ata subcounty was preferred for the study because it cuts across the economic spectrum of the high income households in Karen area, middle income households in Lang'ata area and low income households in Kibera hence the researcher was able to draw objective conclusions from the study findings. A sampling frame was used to come up with a way of selecting participants to be interviewed during the study.

According to Kombo \& Trump, (2006) a sampling frame enables the researcher to come up with a way of choosing particular members of the targeted population to be interviewed in the survey. The research targeted 5 public secondary schools, which are the only public secondary schools in Lang'ata sub-county, which is $100 \%$, way above $30 \%$ recommended by Mugenda (2003). The 5 schools have been in existence for more than five years. The study concentrated on public secondary schools only. Private secondary schools, 41 in number, were excluded from the study because they are not beneficiaries of the government funding through the Free Secondary Education (FSE) policy.

Table 2 List of Public Secondary Schools in Lang'ata Sub-county

\begin{tabular}{|l|l|l|l|}
\hline No & Name of School & Location & Type \\
\hline & & & \\
\hline 1. & Karen 'C' Secondary School & Karen & Public \\
\hline 2. & Lang'ata High School & Lang'ata & Public \\
\hline 3. & Lang'ata Barracks Secondary School & Lang'ata & Public \\
\hline 4. & Olympic High School & Kibera & Public \\
\hline 5. & Raila Educational Centre Secondary School & Kibera & Public \\
\hline
\end{tabular}

\section{Source: Researcher}

\subsection{Sample and Sampling Procedures}

Purposive sampling was used to select five (5) public secondary schools to constitute the sampling unit for the study. From each school, purposive sampling technique was used to select five (5) principals, five (5) school bursars, five (5) Boards of Management (B.O.M) representatives and fifteen (15) Heads of Departments (H.O.Ds) considering that each school has three main departments of Sciences, Languages and Humanities. Simple random sampling was used to select thirty (30) teachers. The sampling technique put into account gender balance hence selecting male and female representatives per department per school hence giving a total of 30 teachers. Simple random sampling technique was also used to select students, considering 10 students per class (Form I - IV), 40 students per school giving a total of two hundred (200) students' representatives. This gave a total of two hundred and sixty (260) participants which was sufficient for the study.

Table 3 Sample size

\begin{tabular}{|l|l|l|l|}
\hline Target Population & Population Size & Sample Size & Percentage \\
\hline & & & \\
\hline
\end{tabular}




\begin{tabular}{|l|l|l|l|}
\hline Principals & 5 & 5 & 100 \\
\hline Bursars & 5 & 5 & 100 \\
\hline Boards of Management Reps. & 5 & 5 & 100 \\
\hline Heads of Departments & 5 & 15 & 100 \\
\hline Teachers Representatives & 5 & 30 & 100 \\
\hline Students Representatives & 5 & 200 & 100 \\
\hline Total & 5 & 260 & 100 \\
\hline
\end{tabular}

\section{Source: Researcher}

\subsection{Description of Research Instruments}

Research instruments are tools that help the researcher to obtain the required information for the study from the field. From a broader perspective, they include questionnaires, interview guides, observation guides, document analysis guides as well as achievement tests. In this study, questionnaires, interview schedules and observation schedules were used.

\subsubsection{Questionnaires:}

According to White (2003), a questionnaire is an instrument with open or closed-ended questions or statements to which a participant must react. Different kinds of questionnaires can be distinguished, such as mailed or posted questionnaires or a group questionnaire. Kumar (2005) defines a questionnaire as a written list of questions, the answers to which are recorded by participants. In a questionnaire the participants read the questions, interpret what is expected and then write down the answers. In this study, open-ended questionnaires will be used because they allow participants to elaborate on their answers. Kumar (2005), notes that an open-ended questionnaire is constructed in such a way that the possible responses are not given. The participants write down the answers in their own words.

Questionnaires were prepared to collect data from principals, bursars, heads of departments, teachers, students and representatives of Boards of Management who are directly linked to the management and running of the public secondary schools in Lang'ata sub-county, Nairobi County. The questionnaires contained items composed of both open and closed ended questions.

To test the validity and reliability of the research instruments, questionnaires were piloted in three selected public secondary schools. The pilot study helped to: Check whether the respondents understand the instructions on the questionnaires for the different groups; establish whether relevant data would be collected from the respondents of the selected public secondary schools; identify problems likely to occur when administering the questionnaires to the various respondents.

\subsubsection{Interview schedule:}

When interview surveys are used, researchers need to establish a cordial relationship and gain the confidence of the interviewee. This often requires training for the interviewee, attending to issues in the process of interviewing, and using an interview schedule. Interviews were conducted on selected principals and representatives of boards of management to establish in detail the challenges of financial resource management in public secondary schools and how they affect students' academic performance. The interview helped to clarify some responses on the questionnaires and also gather information which questionnaires may fail to capture from the various respondents. 


\subsubsection{Observation schedule}

The researcher gathered information through observation during visitations to the selected public secondary schools. Observation helped to verify the responses received through questionnaires and interviews. In order to gain access to the schools, a letter of introduction was obtained from the university. Approval from the Department of Education was sought before commencement of the study. In this regard, the researcher followed the protocol of the Lang'ata sub-county Education Office concerning conducting research in public schools. A letter providing information on the topic and the methodology was provided when the researcher sought approval to conduct the research. This letter was used to obtain permission to enter the schools.

The researcher then visited all five public schools to negotiate access to the participants. The principal was informed verbally of the nature and aim of the study and presented with the research proposal. In addition, the procedure of the study was outlined and the researcher, in his capacity as an educator, then sought permission from the principal to involve teachers and other related stakeholders in this study. Accordingly, gaining access to the schools did not present any problems as the researcher emphasized his role as a postgraduate student completing a prerequisite study in the Faculty of Education.

Once the letter of introduction has been prepared, checked and approved by the relevant University authority, the researcher moves to the field to carry out the research in accordance with the laid down procedures and by using the appropriate instruments. One of the instruments in quantitative research is the questionnaire.

\subsection{Data Validity and Reliability}

The data collected was relied upon for reliability and validity. The data was collected from people who have been involved in the financial resource management in public secondary schools in Lang'ata subcounty, Nairobi County. Other sources of information were historical records kept by the schools and are reputed to be good.

Joppe (2000) argues that validity determines whether the research truly measures what it was intended to measure or how truthful the research results were. Does the research instrument answer the research problem? ; The extent to which results are consistent over time and accurate representation of the total population under study. He says that when the test instruments could be repeated more than once and reproduce similar results, then data could be referred to be reliable.

\subsection{Pilot Test}

According to (Kothari, 2004), before using the questionnaire method, it is always advisable to conduct a pilot study or pilot survey for testing the questionnaires. Such a survey, conducted by experts, brings to the light weaknesses, strengths (if any) of the questionnaires and of the survey techniques hence giving opportunity for relevant improvements.

A pilot test was done on some staff to ensure the validity of the data. The research instruments were pre-tested to confirm that they would serve the intended purpose before being used fully to collect data. The pre-testing was done in three (3) schools which were excluded from the study sample. This was done to ensure reliability of the data collection tools.

\subsection{Data Collection Procedures}

The researcher used both primary and secondary methods of collecting data. A questionnaire was used to collect primary data. In order to identify the challenges in financial resource management, self administered drop and pick questionnaires were distributed to the staff involved in the finance. This enabled the researcher to get adequate and accurate information from people with expertise in public financial management systems. 
The researcher used structured questionnaires as the main data collection instrument. The questions had both open and closed ended questions. The closed- ended questions provided more structured responses and open- ended questions provided more information not covered in the questionnaire. The respondents constituted select five (5) principals, five (5) school bursars, fifteen (15) H.O.Ds and five (5) B.O.M representatives. Simple random sampling was used to select thirty (30) teachers and two hundred (200) students' representatives giving a total of two hundred and sixty (260) participants The data was collected exhaustively to get as much information as possible from staff and stakeholders who have experience in financial resource management and its impact on students' academic performance in public secondary schools in Lang'ata sub-county, Nairobi County.

The secondary data sources were used to supplement the data received from questionnaires. The secondary data were obtained from public expenditure review, budget for the period 2019/2020, Medium Term Expenditure Framework (MTEF) 2018/2021, and the estimates of recurrent expenditure of the government of Kenya which had the allocated fund to the institutions of learning.

\subsection{Data Analysis Procedures}

Before processing the responses, the completed questionnaires were edited for completeness and consistency. A content analysis and descriptive analysis was used. Content analysis was used to analyze the respondent views about challenges in financial management in public secondary schools. The data was processed and grouped into categories. Descriptive analysis was used mainly to summarize the data collected. The data was edited for accuracy, uniformity, completeness and arranged for coding.

A computer programme SPSS version 23 was used to analyze data whereas content analysis was used to analyze some opinions beyond the structured questions. SPSS is a computer package that can be used to generate frequencies, descriptive statistics, tables and graphs. The data was presented using statistical measures, pie charts, bar graphs, frequency tables and graphical presentations.

\subsection{Ethical Considerations}

McMillan and Schumacher (2006) state that researchers need to be sensitive to ethical principles regarding informed consent, confidentiality, anonymity, privacy and being considerate of the participants. In line with ethical practice, the researcher encouraged an atmosphere of voluntary cooperation, trust, openness, value of the respondents as well as confidentiality. Some of the ethical issues in academic research include informed consent, confidentiality, protection against harm, respect for human dignity and privacy among others.

\subsubsection{Informed consent}

The researcher obtained informed consent from all the participants. In the process, each participant was informed of the purpose of the study. They were also assured of the confidentiality of the data obtained. Furthermore, the participants were informed about the procedures to be followed during the research; the advantages and disadvantages of participating in the research and the credibility of the researcher. The researcher paid particular attention to the information provided by the participants. After obtaining their consent, he made it clear to them that they were free to withdraw from the study at any time they wished to do so. This enabled them to make informed, free and voluntary choices regarding their participation.

\subsubsection{Anonymity and confidentiality}

McMillan \& Schumacher (2006) recommend the use of code names for people and places as a practice appropriate for researchers. In this study, the participants were assured of their anonymity and the confidentiality of their responses. Settings such as the schools and personal details of the participants were not identifiable in print. 


\subsubsection{Privacy}

The researcher aimed to maintain privacy by obtaining informed consent of the participants. The use of tape recorders or electronic taping equipment did not take place without the knowledge and consent of the participants. The participants were further assured that they would be free to decline response to certain questions and to decide as well about which information they would not be willing to disclose.

\subsubsection{Competence of the researcher}

According to Barrett, (2007), the researcher is required to identify and empathies with the participants in order to understand them in terms of their own frames of reference. In this study, the researcher followed Strydom's (2005) advice that a researcher should remain sensitive to the needs of the participants and also maintain objectivity and refrain from making value judgments about the points of view of participants, even if they contrast sharply with his/her own values. The researcher thus acknowledged the importance of ensuring that this research was to be conducted in a competent and prudent manner.

\section{Data Analysis And Presentation Of The Results}

\subsection{Introduction}

This chapter four deals with data analysis and presentation of the results according to the thesis questions. The study examined the Financial Resource Management and its Influence on Students' Academic Performance in Public Secondary Schools in Lang'ata Sub-County, Nairobi County-Kenya. Data analysis involves making deductions from the data obtained. The quantitative data was first identified in terms of levels of measurements such as nominal, ordinal, interval or ratio and then coded into the SPSS in order to give it meaning. Descriptive statistics including frequencies and percentages were used to analyze each variable and results presented using frequency distribution tables and bar charts. Nevertheless, qualitative data drawn from open-ended questions was first grouped into a set of themes, assigned numerical value and then entered into the SPSS computer system. The analysis was done using descriptive statistics and presented inform of tables and graphs while others were presented in form of 'verbatim'.

\subsection{Response Rates}

\begin{tabular}{|l|c|c|c|}
\hline Respondent & $\begin{array}{c}\text { Administrated } \\
\text { instruments }\end{array}$ & $\begin{array}{c}\text { Returned } \\
\text { instruments }\end{array}$ & Percentage (\%) \\
\hline Principals & 5 & 5 & $2.08 \%$ \\
\hline Bursars & 5 & 3 & $1.25 \%$ \\
\hline Boards of Management Representatives & 5 & 3 & $1.25 \%$ \\
\hline Heads of Departments & 15 & 11 & $4.58 \%$ \\
\hline Teachers & 30 & 24 & $10.00 \%$ \\
\hline Students & 200 & 194 & $80.83 \%$ \\
\hline Total & $\mathbf{2 6 0}$ & $\mathbf{2 4 0}$ & $\mathbf{1 0 0} \%$ \\
\hline
\end{tabular}

Source: Researcher, 2021

Table 4.1 Response Rates 


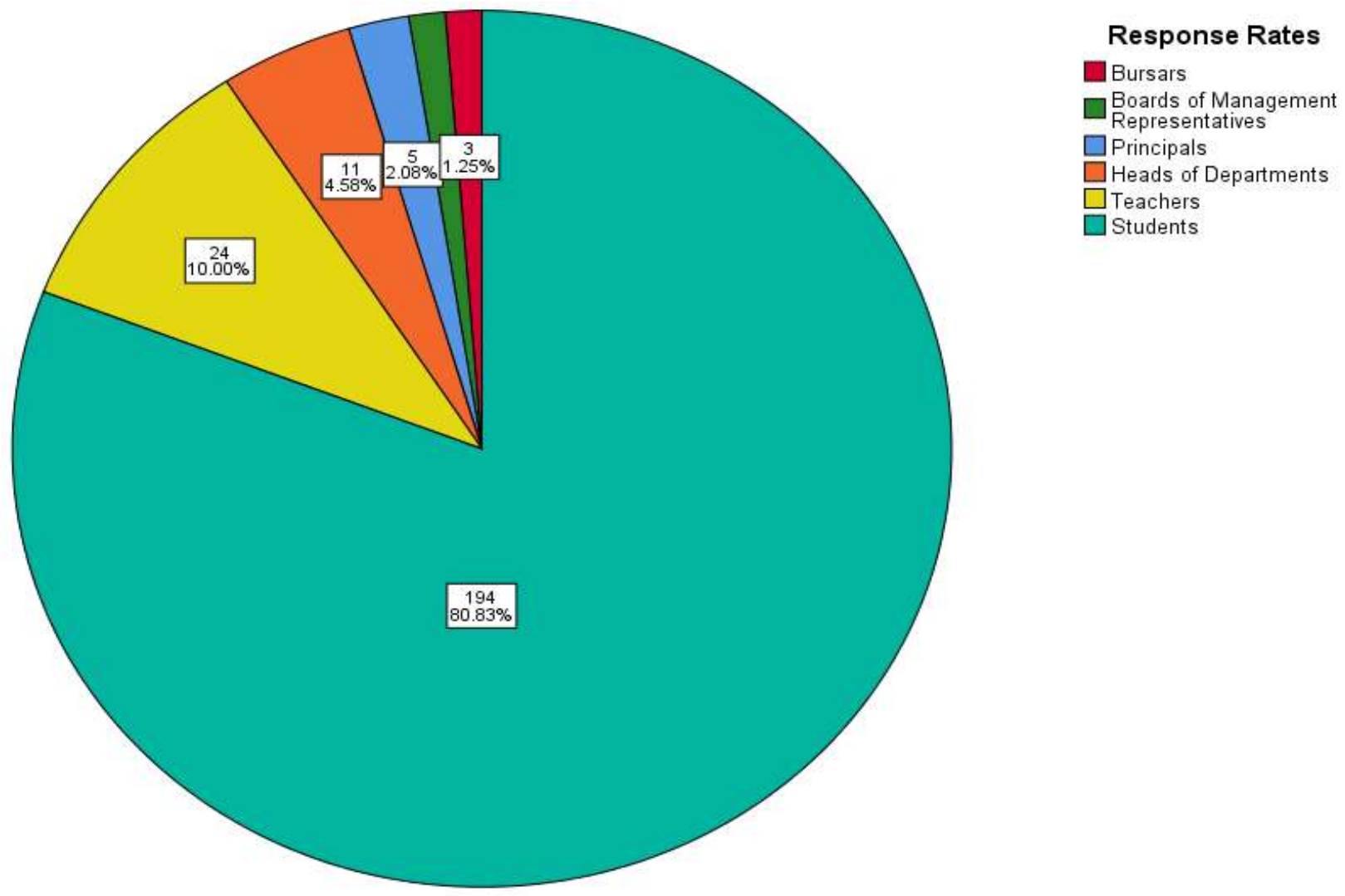

Source: Researcher, 2021

\section{Figure 4.1 Response Rates}

As illustrated in table 4.1 and figure 4.1 above, the researcher administrated a total of 260 questionnaires to 5 principals, 5 Bursars, 5 Boards of Management Representatives, 15 Head of Departments, 30 Teachers, and 200 Students drawn from the five Public Secondary Schools in Lang'ata Sub-County, Nairobi CountyKenya. The Five (5) schools were; Karen 'C' Secondary School, Lang' ata High School, Lang'ata Barracks Secondary School, Olympic High School and Raila Educational Centre Secondary School. Therefore, from the administrated questionnaires only returned questionnaires were 240 respectively. This means that study achieved $92 \%$ return of the rate and this could be attributed to the fact that the researcher created an affinity with the mentioned participants in the targeted schools who were supportive during the process of data collection. 


\subsection{General Information - Principal}

\# Principal Response: 5 participants

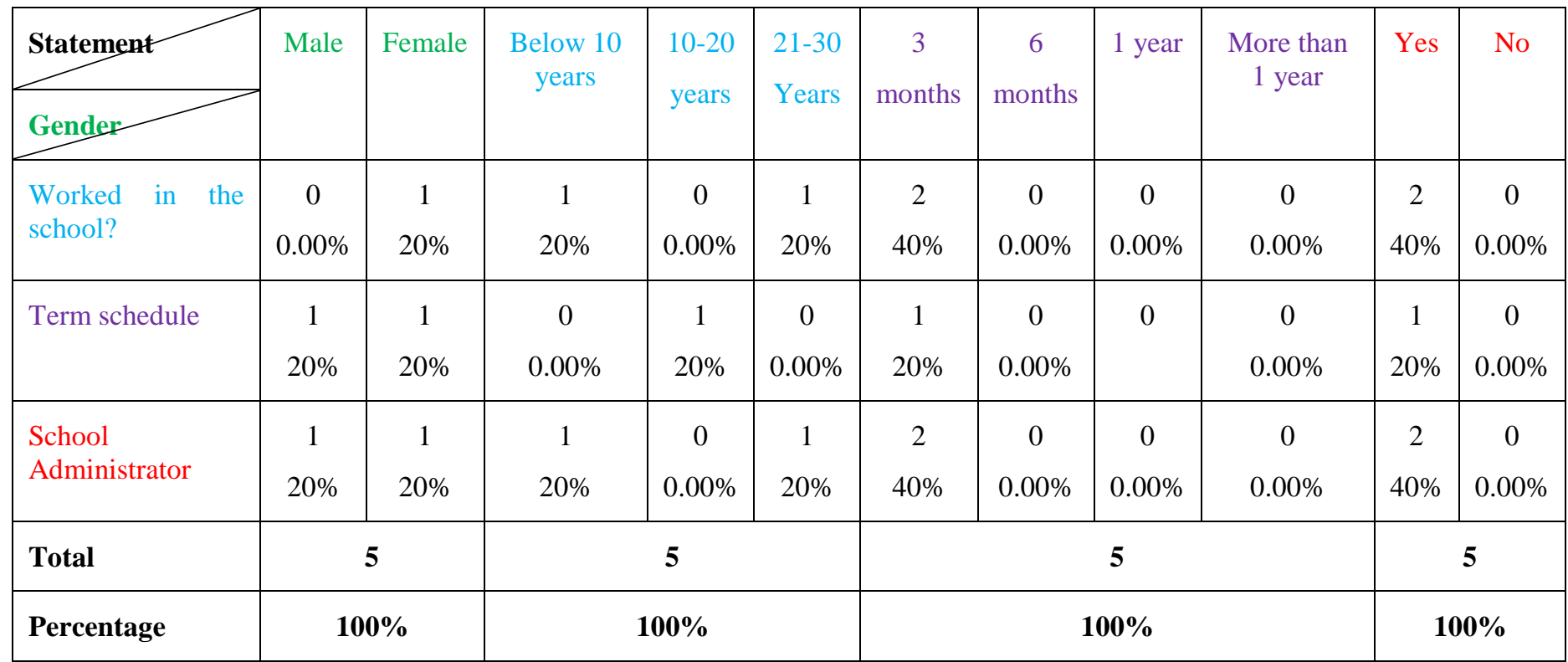

\section{Source: Researcher, 2021}

\section{Table 4.2 General Information (Principal)}

Table 4.2 above explains the gender of the principals participated in this study, as shown that (60\%) of the respondents were female while their counterpart were male with $(40 \%)$ respectively. Furthermore, the researcher asked about the work experience and found out that majority of the respondents worked below 10 years and between 21-30 years with a percentage of (40\%) each, while others with a (20\%) between 10-20 years 
respectively. Nevertheless, the participants were asked about the term schedule covered by the school administration, and (100\%) responded that the term schedule covered a period of 3 months. Finally, the researcher asked the participants concerning the following question that says; do you think the secondary school administrators get enough time to prepare for the task prior to their appointment? And the participants' response was (100\%) YES, while zero response from NO zone.

Nevertheless, the researcher distributed the following questions as an interview guide for the schools' principals as follows: how is the school principal involved in the preparation of the budget?; how is the Board of Management involved in the budget process?; how is the Finance Committee involved in the process of budgeting?; is there a finance policy in the school?; does it detail how the budget process should be followed?; how do you get information for the budget?; who reviews the budget before it is presented to the school board for approval?; would you say your school does pre- control, concurrent control and post control of the budget?; and how does the budget affect the academic performance in the school?. Therefore the participants stated the following;

"The school principal is well involved in all the preparation of the budget process in the school. The board of management is perfectly called in by the board of finance committee. The finance committees are the one in charge of the budget implementation in the school. Fully the school has annual plan for the finance committee of the school. Yes it does all the time. Well; all the information concerning the budget process are brought to my attention by the top management and the finance committee in general. The finance committees are the one who do the reviewing of the budget before presenting to the top management and the school principal. The school does a full control of the budget always. Well; most of the time when ministry of the education/ teachers union boards delays teachers' salaries, which lead to withdrawal of teachers during teaching schedule and that cause lower performance of students in general."

\section{Source: Interviewers, 2021}

On the other hand; the researcher interviewed the participants with a few questions asking them that; how does the school principal ensure that the school's expenditure is in line with the budgeted finances?, is the school principal fully involved in the implementation of the school budget?, is the actual expenditure compared to the budgeted finances in the course of budget implementation?, how are variances in the budget identified?, how are they reported to the finance committee and the Board of Management (BOM)?, how are corrective measures taken when there are significant variances in the budget?, and how does effective financial management affect students' academic performance? Therefore, the participants' response was as follows;

“The school's Principal always had his/her annual plans, which was drafted from the top management, finance committee and heads of departments (teachers), that's allows his/her to review all the budgeting process correctly. Yes as the head of the school all the programs, projects, budgets are brought to me fully by the top management and the school organs. Yes it's true the actual expenditure is drafted from the annual finance report of the school. Variances are always identified through the quarterly finance report or the annual finance reports, through a quarterly meeting that which is conducted by the principal of the school. A quick meeting will be brought to the school principal by the top management in order to facilitate the issues of variances, once discovered. Well; as you heard about it from the top management, most of the time or other teachers get frustrated because of the delayed salaries or sometimes because of misconduct or misuse of funds (school budget) of office by the finance committee."

Source: Interviewers, 2021 
Finally, the researcher had drafted the following questions to get how the school's principal handle the budget and his/her experience in the implementation of the school budgetary allocations. Therefore, the following are the questions; does actual expenditure sometimes exceed or fall far below from the budget?, how often does this happen?, what are the most common reasons for this?, how does the school principal contribute to the variances in the school budget?, how are budget variances corrected - such that they do not happen again?, what challenges do you experience in the implementation of the school budgetary allocations?, and do the challenges adversely affect the students' academic performance?. Therefore, the participants' demonstrated their thoughts as follows;

"Indeed, not only in the secondary schools where you find that the actual expenditures has exceed its mandate, therefore, its evidence from the top management and the financial committee that; sometimes they do have extra activities comes in late, which sometimes cause fall from the budget that was planned. Once quarterly or sometimes; in the second school term. To fully manage the school budgets and gives hopes to the less fortunate students who are brought by good Samaritans to study; therefore, it's a mass for the school's principal to review the school budget more than once.

Well, let say in general most of the secondary school principal are well concerned about everything that takes place in the school environment, therefore, the school's principal are the one who sometimes make the final decision after analysis of top management to give the go ahead. The variances are corrected through a continuous meeting by the principal and the top management to finalize the situation in order for it not to happen again. Okay; as the school's principal, you always have challenges eg, implementing of budget especially when you have pathetic administration or lower budget and all are counting on you to do something about. Of course, any wrong plans by the top management or the principal affect the entire school, especially our fortunate students' academic performance, because they depends a lots on what the teacher provide in class."

\section{Source: Interviewers, 2021}

Therefore, this implies that in order to understand the education policies posing challenges to school principals in terms of financial resource management, it is proper to have a brief recourse to the constitution on which such policies are anchored. Nevertheless, principals face the challenges of delayed disbursement of funds allocations, hence slowing down school operations which in the long run affect the performance of our fortunate students, who depend on good well wishes to provide for them, Rok, (2008). 


\subsubsection{Influence of Budget Management}

Relationship between financial resource management and students' academic performance in public secondary schools in Lang'ata sub-county, Nairobi County: Therefore, financial resources have a number of purposes; indicate how important you think that each of the following is relevant; using a rating scale of 1 to 5 , please indicate (tick) the importance of the statement on the financial resource management and students' academic performance.

\begin{tabular}{|c|c|c|c|c|c|}
\hline \multirow[t]{2}{*}{ Statement } & 5 & 4 & 3 & 2 & 1 \\
\hline & $\begin{array}{l}\text { Strongly } \\
\text { agree }\end{array}$ & Agree & Neutral & Disagree & $\begin{array}{l}\text { Strongly } \\
\text { disagree }\end{array}$ \\
\hline $\begin{array}{l}\text { Financial resources are used to forecast the } \\
\text { future and therefore good for planning }\end{array}$ & $\begin{array}{c}3 \\
60 \%\end{array}$ & $\begin{array}{c}2 \\
40 \%\end{array}$ & $\begin{array}{c}0 \\
0.00 \%\end{array}$ & $\begin{array}{c}0 \\
0.00 \%\end{array}$ & $\begin{array}{c}0 \\
0.00 \%\end{array}$ \\
\hline $\begin{array}{l}\text { Financial resources are used to control other } \\
\text { resources }\end{array}$ & $\begin{array}{c}2 \\
40 \%\end{array}$ & $\begin{array}{c}3 \\
60 \%\end{array}$ & $\begin{array}{c}0 \\
0.00 \%\end{array}$ & $\begin{array}{c}0 \\
0.00 \%\end{array}$ & $\begin{array}{c}0 \\
0.00 \%\end{array}$ \\
\hline $\begin{array}{l}\text { Budgets are used to communicate to other } \\
\text { levels in the departments }\end{array}$ & $\begin{array}{c}4 \\
80 \%\end{array}$ & $\begin{array}{c}1 \\
20 \%\end{array}$ & $\begin{array}{c}0 \\
0.00 \%\end{array}$ & $\begin{array}{c}0 \\
0.00 \%\end{array}$ & $\begin{array}{c}0 \\
0.00 \%\end{array}$ \\
\hline $\begin{array}{l}\text { Financial resources are used to judge } \\
\text { students' academic performance }\end{array}$ & $\begin{array}{c}0 \\
0.00 \%\end{array}$ & $\begin{array}{c}0 \\
0.00 \%\end{array}$ & $\begin{array}{c}1 \\
20 \%\end{array}$ & $\begin{array}{c}1 \\
20 \%\end{array}$ & $\begin{array}{c}3 \\
60 \%\end{array}$ \\
\hline $\begin{array}{l}\text { They are used to motivate employees to do } \\
\text { better }\end{array}$ & $\begin{array}{c}3 \\
60 \%\end{array}$ & $\begin{array}{c}1 \\
20 \%\end{array}$ & $\begin{array}{c}1 \\
20 \%\end{array}$ & $\begin{array}{c}0 \\
0.00 \%\end{array}$ & $\begin{array}{c}0 \\
0.00 \%\end{array}$ \\
\hline
\end{tabular}

\section{Source: Researcher, 2021}

\section{Table 4.3 Influence of Budget Management- Principal}

According to table 4.3 above, majority of the respondents with $(60 \%)$ strongly agreed that Financial resources are used to forecast the future and therefore good for planning, while $(60 \%)$ of the participants agreed that Financial resources are used to control other resources, nevertheless (80\%) strongly agreed that Budgets are used to communicate to other levels in the departments, $(60 \%)$ of the respondents strongly agreed that Financial resources are used to judge students' academic performance, and (60\%) strongly agreed that they are used to motivate employees to do better. Therefore, this implies that, the management of resources "financial resource management" in the institutions of learning eg. Secondary schools, plays a central role to achieve desirable outcomes of the institution. Nyongesa, (2007). This gives them the mandate to mobilize resources and to ensure school effectiveness through improving students' academic performance.

\subsubsection{Influence of Financial Controls}

The extent to which financial resource management affect students' academic performance in public secondary schools in Lang'ata sub-county, Nairobi County: Using a rating scale of 1 to 5, please indicate (tick) the importance of the statement on the extent to which financial resource management affect students' academic performance.

\begin{tabular}{|l|c|c|c|c|c|}
\hline Statement & 5 & 4 & 3 & 2 & 1 \\
\cline { 2 - 5 } & $\begin{array}{c}\text { Strongly } \\
\text { Agree }\end{array}$ & Agree & Neutral & Disagree & $\begin{array}{c}\text { Strongly } \\
\text { Disagree }\end{array}$ \\
\hline
\end{tabular}




\begin{tabular}{|c|c|c|c|c|c|}
\hline $\begin{array}{l}\text { The institution issues budget guidelines } \\
\text { prior to the preparation of the budget }\end{array}$ & $\begin{array}{c}4 \\
80 \%\end{array}$ & $\begin{array}{c}1 \\
20 \%\end{array}$ & $\begin{array}{c}0 \\
0.00 \%\end{array}$ & $\begin{array}{c}0 \\
0.00 \%\end{array}$ & $\begin{array}{c}0 \\
0.00 \%\end{array}$ \\
\hline $\begin{array}{l}\text { All the staff participate in the } \\
\text { preparation of the budget and } \\
\text { discussions within their departments }\end{array}$ & $\begin{array}{c}4 \\
80 \%\end{array}$ & $\begin{array}{c}1 \\
20 \%\end{array}$ & $\begin{array}{c}0 \\
0.00 \%\end{array}$ & $\begin{array}{c}0 \\
0.00 \%\end{array}$ & $\begin{array}{c}0 \\
0.00 \%\end{array}$ \\
\hline $\begin{array}{l}\text { Planning is important to the success of } \\
\text { the students in examinations }\end{array}$ & $\begin{array}{c}5 \\
100 \%\end{array}$ & $\begin{array}{c}0 \\
0.00 \%\end{array}$ & $\begin{array}{c}0 \\
0.00 \%\end{array}$ & $\begin{array}{c}0 \\
0.00 \%\end{array}$ & $\begin{array}{c}0 \\
0.00 \%\end{array}$ \\
\hline $\begin{array}{l}\text { There is proper communication during } \\
\text { the process of teaching and learning }\end{array}$ & $\begin{array}{c}4 \\
80 \%\end{array}$ & $\begin{array}{c}1 \\
20 \%\end{array}$ & $\begin{array}{c}0 \\
0.00 \%\end{array}$ & $\begin{array}{c}0 \\
0.00 \%\end{array}$ & $\begin{array}{c}0 \\
0.00 \%\end{array}$ \\
\hline $\begin{array}{l}\text { Support provided to the subordinate } \\
\text { staff during the school Term is effective }\end{array}$ & $\begin{array}{c}2 \\
40 \%\end{array}$ & $\begin{array}{c}3 \\
60 \%\end{array}$ & $\begin{array}{c}0 \\
0.00 \%\end{array}$ & $\begin{array}{c}0 \\
0.00 \%\end{array}$ & $\begin{array}{c}0 \\
0.00 \%\end{array}$ \\
\hline $\begin{array}{l}\text { Coordination among the various } \\
\text { departments during the school Term } \\
\text { improve academic performance }\end{array}$ & $\begin{array}{c}3 \\
60 \%\end{array}$ & $\begin{array}{c}2 \\
40 \%\end{array}$ & $\begin{array}{c}0 \\
0.00 \%\end{array}$ & $\begin{array}{c}0 \\
0.00 \%\end{array}$ & $\begin{array}{c}0 \\
0.00 \%\end{array}$ \\
\hline $\begin{array}{l}\text { The management can be able to } \\
\text { overcome the challenges of budget } \\
\text { implementation }\end{array}$ & $\begin{array}{c}2 \\
40 \%\end{array}$ & $\begin{array}{c}3 \\
60 \%\end{array}$ & $\begin{array}{c}0 \\
0.00 \%\end{array}$ & $\begin{array}{c}0 \\
0.00 \%\end{array}$ & $\begin{array}{c}0 \\
0.00 \%\end{array}$ \\
\hline
\end{tabular}

\section{Source: Researcher, 2021}

\section{Table 4.4 Influence of Financial Controls- Principal}

Its true from table 4.4 above, that majority of the respondents with (80\%) strongly agreed that the institution issues budget guidelines prior to the preparation of the budget, $(80 \%)$ strongly agreed that all the staff participate in the preparation of the budget and discussions within their departments, while (100\%) of the participants strongly agreed that planning is important to the success of the students in examinations, additionally (80\%) strongly agreed that there is proper communication during the process of teaching and learning, (60\%) agreed that support provided to the subordinate staff during the school Term is effective, nevertheless ( 60\%) strongly agreed that Coordination among the various departments during the school Term improve academic performance, and ( 60\%) agreed that the management can be able to overcome the challenges of budget implementation. This shows that, financial management or influence of financial controls in public secondary schools are concerned with defining the goals, and developing programs that will insure the convert such as goals into monetary values at all time. Furthermore, proper financial management is very essential for the success of an institution, Mwenda and Gachocho, (2003).

\subsubsection{Challenges principals of public secondary schools face}

Challenges principals of public secondary schools face in the management of finance; using a rating scale of 1 to 5 , please indicate (tick) the importance of the statement on the challenges facing students' academic performance.

\begin{tabular}{|l|c|c|c|c|c|}
\hline \multicolumn{1}{|c|}{ Statement } & $\mathbf{5}$ & $\mathbf{4}$ & $\mathbf{3}$ & $\mathbf{2}$ & $\mathbf{1}$ \\
\cline { 2 - 6 } & $\begin{array}{c}\text { Strongly } \\
\text { Agree }\end{array}$ & Agree & Neutral & Disagree & $\begin{array}{l}\text { Strongly } \\
\text { disagree }\end{array}$ \\
\hline $\begin{array}{l}\text { In some cases budget include unattainable } \\
\text { targets or standards }\end{array}$ & 2 & 2 & 1 & 0 & 0 \\
\hline $\begin{array}{l}\text { Insufficient funds allocation affect the } \\
\text { implementation of the school programs }\end{array}$ & $40 \%$ & $40 \%$ & $20 \%$ & $0.00 \%$ & $0.00 \%$ \\
\hline
\end{tabular}




\begin{tabular}{|l|c|c|c|c|c|}
\hline $\begin{array}{l}\text { Inability of departments to utilize the } \\
\text { allocated funds hinders the effective } \\
\text { teaching and learning }\end{array}$ & $\begin{array}{c}3 \\
60 \%\end{array}$ & $\begin{array}{c}2 \\
40 \%\end{array}$ & $\begin{array}{c}0 \\
0.00 \%\end{array}$ & $\begin{array}{c}0 \\
0.00 \%\end{array}$ & $0.00 \%$ \\
\hline $\begin{array}{l}\text { The methods used to allocate funds to the } \\
\text { departments are unsatisfactory }\end{array}$ & 0 & 0 & 0 & 3 & 2 \\
\hline $\begin{array}{l}\text { Reforms in school financial management } \\
\text { come up with new rules which affect } \\
\text { students' academic performance }\end{array}$ & $0.00 \%$ & $0.00 \%$ & $0.00 \%$ & $60 \%$ & $40 \%$ \\
\hline
\end{tabular}

\section{Source: Researcher, 2021}

\section{Table 4.5 Challenges Principals face- Principal}

According to table 4.5 above, majority of the participants with (40\%) strongly agreed and agreed fully that in some cases budget include unattainable targets or standards, (80\%) strongly agreed that insufficient funds allocation affect the implementation of the school programs, while $(60 \%)$ strongly agreed that Inability of departments to utilize the allocated funds hinders the effective teaching and learning, additionally ( $60 \%$ ) disagreed that The methods used to allocate funds to the departments are unsatisfactory, and (40\%) were neutral and strongly disagreed that reforms in school financial management come up with new rules which affect students' academic performance. This implies that, most of time emphases on accountability are laid on the principal more than the top management, especially institutions in urban area or slums such as Kibera. Therefore, most of the policies of the school are implemented or directed by the principals, especial one it comes to the influences of the budget and priorities for resources allocation at any public secondary schools institutions, Crouch \& Winker, (2008). 
4.4 General Information - Bursars/ Boards of Management Reps

\# Bursars/ Boards of Management Representatives - Response: 6 participants

\begin{tabular}{|c|c|c|c|c|c|c|c|c|c|c|c|c|c|c|}
\hline Gender & $\begin{array}{c}\text { Mal } \\
\mathrm{e}\end{array}$ & $\begin{array}{c}\text { Fema } \\
\text { le }\end{array}$ & $\begin{array}{l}\text { Administr } \\
\text { ator }\end{array}$ & $\begin{array}{c}\text { Financ } \\
\text { ial } \\
\text { Manag } \\
\text { er }\end{array}$ & $\begin{array}{c}\text { Account } \\
\text { ant }\end{array}$ & $\begin{array}{l}\text { Belo } \\
\text { w } 10 \\
\text { year } \\
\text { s }\end{array}$ & $\begin{array}{l}10- \\
20 \\
\text { year } \\
\text { s }\end{array}$ & $\begin{array}{c}21- \\
30 \\
\text { year } \\
\mathrm{s}\end{array}$ & $\begin{array}{c}3 \\
\text { mont } \\
\text { hs }\end{array}$ & $\begin{array}{c}6 \\
\text { mont } \\
\text { hs }\end{array}$ & $\begin{array}{c}1 \\
\text { year }\end{array}$ & $\begin{array}{c}\text { Mor } \\
\text { e } \\
\text { than } \\
1 \\
\text { year }\end{array}$ & Yes & No \\
\hline \multirow{2}{*}{$\begin{array}{l}\text { Functiona } \\
1 \text { position }\end{array}$} & 1 & 1 & 2 & 1 & 0 & 2 & 1 & 0 & 2 & 0 & 0 & 0 & 2 & 0 \\
\hline & $\begin{array}{c}16.6 \\
\%\end{array}$ & $\begin{array}{c}16.6 \\
\%\end{array}$ & $33.6 \%$ & $16.6 \%$ & $0.00 \%$ & $\begin{array}{c}33.6 \\
\%\end{array}$ & $\begin{array}{c}16.6 \\
\%\end{array}$ & $\begin{array}{c}0.00 \\
\%\end{array}$ & $\begin{array}{c}33.6 \\
\%\end{array}$ & $\begin{array}{c}0.00 \\
\%\end{array}$ & $\begin{array}{c}0.00 \\
\%\end{array}$ & $\begin{array}{c}0.00 \\
\%\end{array}$ & $\begin{array}{c}33.6 \\
\%\end{array}$ & $\begin{array}{c}0.00 \\
\%\end{array}$ \\
\hline \multirow{2}{*}{$\begin{array}{l}\text { Worked in } \\
\text { the } \\
\text { school? }\end{array}$} & 0 & 2 & 0 & 0 & 0 & 0 & 0 & 1 & 1 & 0 & 0 & 0 & 2 & 0 \\
\hline & $\begin{array}{c}0.00 \\
\%\end{array}$ & $\begin{array}{c}33.6 \\
\%\end{array}$ & $0.00 \%$ & $0.00 \%$ & $0.00 \%$ & $\begin{array}{c}0.00 \\
\%\end{array}$ & $\begin{array}{c}0.00 \\
\%\end{array}$ & $\begin{array}{c}16.6 \\
\%\end{array}$ & $\begin{array}{c}16.6 \\
\%\end{array}$ & $\begin{array}{c}0.00 \\
\%\end{array}$ & $\begin{array}{c}0.00 \\
\%\end{array}$ & $\begin{array}{c}0.00 \\
\%\end{array}$ & $\begin{array}{c}33.6 \\
\%\end{array}$ & $\begin{array}{c}0.00 \\
\%\end{array}$ \\
\hline \multirow{2}{*}{$\begin{array}{l}\text { Term } \\
\text { schedule }\end{array}$} & 1 & 0 & 0 & 1 & 1 & 1 & 1 & 0 & 2 & 0 & 0 & 0 & 1 & 0 \\
\hline & $\begin{array}{c}16.6 \\
\%\end{array}$ & $\begin{array}{c}0.00 \\
\%\end{array}$ & $0.00 \%$ & $16.6 \%$ & $16.6 \%$ & $\begin{array}{c}16.6 \\
\%\end{array}$ & $\begin{array}{c}16.6 \\
\%\end{array}$ & $\begin{array}{c}0.00 \\
\%\end{array}$ & $\begin{array}{c}33.6 \\
\%\end{array}$ & $\begin{array}{c}0.00 \\
\%\end{array}$ & $\begin{array}{c}0.00 \\
\%\end{array}$ & $\begin{array}{c}0.00 \\
\%\end{array}$ & $\begin{array}{c}16.6 \\
\%\end{array}$ & $\begin{array}{c}0.00 \\
\%\end{array}$ \\
\hline \multirow{2}{*}{$\begin{array}{l}\text { School } \\
\text { Administr } \\
\text { ator }\end{array}$} & 0 & 1 & 0 & 1 & 0 & 0 & 0 & 0 & 1 & 0 & 0 & 0 & 1 & 0 \\
\hline & $\begin{array}{c}0.00 \\
\%\end{array}$ & $\begin{array}{c}16.6 \\
\%\end{array}$ & $0.00 \%$ & $16.6 \%$ & $0.00 \%$ & $\begin{array}{c}0.00 \\
\%\end{array}$ & $\begin{array}{c}0.00 \\
\%\end{array}$ & $\begin{array}{c}0.00 \\
\%\end{array}$ & $\begin{array}{c}16.6 \\
\%\end{array}$ & $\begin{array}{c}0.00 \\
\%\end{array}$ & $\begin{array}{c}0.00 \\
\%\end{array}$ & $\begin{array}{c}0.00 \\
\%\end{array}$ & $\begin{array}{c}16.6 \\
\%\end{array}$ & $\begin{array}{c}0.00 \\
\%\end{array}$ \\
\hline Total & \multicolumn{2}{|c|}{6} & \multicolumn{3}{|c|}{6} & \multicolumn{3}{|c|}{6} & \multicolumn{4}{|c|}{6} & \multicolumn{2}{|c|}{6} \\
\hline $\begin{array}{l}\text { Percenta } \\
\text { ge }\end{array}$ & \multicolumn{2}{|c|}{$100 \%$} & \multicolumn{3}{|c|}{$100 \%$} & \multicolumn{3}{|c|}{$100 \%$} & \multicolumn{4}{|c|}{$100 \%$} & \multicolumn{2}{|c|}{$100 \%$} \\
\hline
\end{tabular}

Source: Researcher, 2021

Table 4.6 General Information - Bursars/ Boards of Management Reps 
Table 4.6 above shows that, majority of the respondents with (66.8\%) were female while their counterpart male with (33.2\%), furthermore they were asked about their functional position in the school, which shown that majority of the participants were financial managers with $(49.8 \%)$ while, $(33.6 \%)$ were administrators, and $(16.6 \%)$ were accountants respectively. Nevertheless, they were asked about the years of experiences they worked in the school; majority were below 10 years with $(50.2 \%)$ while $(33.2 \%)$ were between $10-20$ years worked experiences, and (16.6\%) were between 21-30 years worked experiences. Additionally, they were asked about their term schedule of the school and the response was as follows; majority with (100\%) of the participants said that the school term schedule is 3 months period. Finally, the researcher distributed questions about school administrators that do you think the secondary school administrators get enough time to prepare for the task prior to their appointment, and the participants said that with a majority of (100\%) YES that the administrators do get enough time to prepare for the task prior to their appointment respectively.

Nevertheless, the researcher drafted out the following question in order to understanding how the bursars, boards of management representatives handle the process of budgeting in the schools. Therefore, the question as follows; how is the Finance Committee involved in the process of budgeting?, is there a finance policy in the school?, does it detail how the budget process should be followed?, how do you get information for the budget?, who reviews the budget before it is presented to the school board for approval?, would you say your school does pre- control, concurrent control and post -control of the budget?, and how does the budget affect the academic performance in the school?. The participants contributed their thoughts concerning the above mentioned questions, as follows;

\begin{abstract}
"Truly, the finance committees are well involved in any drafted budget process in the school. Yes, its evidence that any institution do have finance policy, therefore the secondary schools has fully plans for finance policy. Indeed, all the institutions shows how budget process should be followed by any top management or finance committee members, therefore, it's true the schools allows the top management and the members of the finance committee to follow its annual plans. Well, most of us get the budget information directly from the finance committee, but some who are somehow closer to the principal get the information faster.
\end{abstract}

The finance committees are the one involves in reviewing of the school budget before its present to the top management and the principal. Indeed, the school does fully pre-control, concurrent control and post-control of the budget quarterly or sometimes after the second term of the school schedule. Well, school budget or financial budgeting allows affects schools timetable if not treated on time, therefore, it can cause a big blow to the students to pursue their dreams of study."

\title{
Source: Interviewers, 2021
}

Additionally, the researcher interviewed the participants, concerning how they deal with the school expenditures at all times. Therefore, the questions are as follows; how do you ensure that the school's expenditure is in line with the budgeted amounts?, is the actual expenditure compared to the budgeted amounts in the course of budget implementation?, how are variances in the budget identified?, how are they reported to the finance committee and the Board of Management (BOM)?, and how are corrective measures taken when there are significant variances in the budget?. Therefore, the participants stated that;

“ It's done through a frequent meeting by the finance committees, top management and the school principal, which allows not gap for extra un-plan activities. Yes, it's compared to the budgeted amounts at all time. The variances are identified through the frequent review of the quarterly or the annual finance budget of the school. They are reported to the finance committees and the board of management, through a frequent/ quick meetings 
conducted by the top management and the school principal. The corrective measures are always taken through the school organs meetings."

Source: Interviewers, 2021

Nevertheless, the researcher interviewed the participants, concerning how they deal with the budget variances correction in the schools. Therefore, the questions are as follows; does actual expenditure sometimes exceed or fall far below from the budget?, how often does this happen?, what are the most common reasons for this?, how are budget variances corrected - such that they do not happen again?, what challenges do you experience in the implementation of the school budgetary allocations?, do the challenges adversely affect the students' academic performance?. Therefore, these are the response by the participants indicated below;

\begin{abstract}
"Yes, it does exceed and sometimes it fall far below the actual budgeted. It happens once, maybe through holidays. The most common of it, is through finance committees failing to report the budget on time. They are corrected through a quick call in meeting by the top management and the school principal. The challenges do finance committees or top management experience is that when the funds comes from parents or any good will-wishes person, directly to the school account and you find that the relationship between the management the principal is very weak, and which leads to lots of funds which are not account by the finance committee, and will later leads to unaccounted budget or office misconduct. Indeed, such challenges course a clear disagreement between the finance committees and principal, and which sometimes reached to the teachers, which will course un-confidence of teaching class. Therefore, it leads to lower academic performance of the students in general."
\end{abstract}

\title{
Source: Interviewers, 2021
}

Therefore, this explains that the characteristic of such an approach to education management in general and financial management in particular, is the emphasis on transparency and information sharing among all stakeholders. For the school principal, finance committees, bursars and Board of Management, this means that they must deal with funds in a responsible manner and that they are accountable to the parents, students, community within the school area, Deventer and Kruger (2003).

\subsubsection{Influence of Budget Management}

Relationship between financial resource management and students' academic performance in public secondary schools in Lang'ata sub-county, Nairobi County: Therefore, financial resources have a number of purposes; indicate how important you think that each of the following is relevant; using a rating scale of 1 to 5 , please indicate (tick) the importance of the statement on the financial resource management and students' academic performance.

\begin{tabular}{|l|c|c|c|c|c|}
\hline \multicolumn{1}{|c|}{ Statement } & $\mathbf{5}$ & $\mathbf{4}$ & $\mathbf{3}$ & $\mathbf{2}$ & $\mathbf{1}$ \\
\cline { 2 - 6 } & $\begin{array}{c}\text { Strongly } \\
\text { agree }\end{array}$ & Agree & Neutral & Disagree & $\begin{array}{c}\text { Strongly } \\
\text { disagree }\end{array}$ \\
\hline $\begin{array}{l}\text { Financial resources are used to forecast the } \\
\text { future and therefore good for planning }\end{array}$ & $\begin{array}{c}3 \\
50 \%\end{array}$ & $\begin{array}{c}1 \\
16.6 \%\end{array}$ & $\begin{array}{c}2 \\
33.4 \%\end{array}$ & $0.00 \%$ & $0.00 \%$ \\
\hline $\begin{array}{l}\text { Financial resources are used to control other } \\
\text { resources }\end{array}$ & $16.6 \%$ & $33.4 \%$ & $16.6 \%$ & $16.6 \%$ & $16.6 \%$ \\
\hline
\end{tabular}




\begin{tabular}{|l|c|c|c|c|c|}
\hline $\begin{array}{l}\text { Budgets are used to communicate to other } \\
\text { levels in the departments }\end{array}$ & $\begin{array}{c}3 \\
50 \%\end{array}$ & $\begin{array}{c}2 \\
33.4 \%\end{array}$ & $\begin{array}{c}1 \\
16.6 \%\end{array}$ & $\begin{array}{c}0 \\
0.00 \%\end{array}$ & $0.00 \%$ \\
\hline $\begin{array}{l}\text { Financial resources are used to judge } \\
\text { students' academic performance }\end{array}$ & $\begin{array}{c}1 \\
16.6 \%\end{array}$ & $\begin{array}{c}2 \\
33.4 \%\end{array}$ & $\begin{array}{c}3 \\
50 \%\end{array}$ & $\begin{array}{c}1 \\
16.6 \%\end{array}$ & $0.00 \%$ \\
\hline $\begin{array}{l}\text { They are used to motivate employees to do } \\
\text { better }\end{array}$ & $\begin{array}{c}2 \\
33.4 \%\end{array}$ & $\begin{array}{c}1 \\
16.6 \%\end{array}$ & $\begin{array}{c}2 \\
33.4 \%\end{array}$ & $\begin{array}{c}1 \\
16.6 \%\end{array}$ & $0.00 \%$ \\
\hline
\end{tabular}

\section{Source: Researcher, 2021}

\section{Table 4.7 Influence of Budget Management-Bursars/ Boards of Management Reps}

As illustrated by table4.7 above, majority of the participants with (50\%) strongly agreed that Financial resources are used to forecast the future and therefore good for planning, (33.4\%) agreed that Financial resources are used to control other resources, while (50\%) strongly agreed that Budgets are used to communicate to other levels in the departments, additionally ( $50 \%)$ were neutral concerning their opinion on the Financial resources are used to judge students' academic performance, and (33.4\%) both strongly agreed and were neutral on their opinion on the idea that they are used to motivate employees to do better. This shows that, financial numeracy is a core skill for all managers. Most financial management skills involve the allocation of resources and the setting of targets, expectations and priorities. The main financial skills required by all school managers to enable them perform their duties successfully are budgeting, budget management and management of costs. Moreover, communication plays an integral part of financial management, Owen (2006).

\subsubsection{Influence of Financial Controls}

The extent to which financial resource management affect students' academic performance in public secondary schools in Lang'ata sub-county, Nairobi County: Using a rating scale of 1 to 5, please indicate (tick) the importance of the statement on the extent to which financial resource management affect students' academic performance.

\begin{tabular}{|l|c|c|c|c|c|}
\hline \multicolumn{1}{|c|}{ Statement } & $\mathbf{5}$ & $\mathbf{4}$ & $\mathbf{3}$ & $\mathbf{2}$ & $\mathbf{1}$ \\
\cline { 2 - 5 } & $\begin{array}{l}\text { Strongly } \\
\text { Agree }\end{array}$ & Agree & Neutral & Disagree & $\begin{array}{c}\text { Strongly } \\
\text { Disagree }\end{array}$ \\
\hline $\begin{array}{l}\text { The institution issues budget guidelines } \\
\text { prior to the preparation of the budget }\end{array}$ & $50 \%$ & $33.4 \%$ & $16.6 \%$ & $0.00 \%$ & $0.00 \%$ \\
\hline $\begin{array}{l}\text { All the staff participate in the } \\
\text { preparation of the budget and } \\
\text { discussions within their departments }\end{array}$ & $33.4 \%$ & $66.6 \%$ & $0.00 \%$ & $0.00 \%$ & $0.00 \%$ \\
\hline $\begin{array}{l}\text { Planning is important to the success of } \\
\text { the students in examinations }\end{array}$ & 4 & 2 & 0 & 0 & 0 \\
\hline $\begin{array}{l}\text { There is proper communication during } \\
\text { the process of teaching and learning }\end{array}$ & $50.6 \%$ & $33.4 \%$ & $0.00 \%$ & $0.00 \%$ & $0.00 \%$ \\
\hline
\end{tabular}




\begin{tabular}{|l|c|c|c|c|c|}
\hline $\begin{array}{l}\text { Support provided to the subordinate } \\
\text { staff during the school Term is effective }\end{array}$ & $\begin{array}{c}4 \\
66.6 \%\end{array}$ & $\begin{array}{c}1 \\
16.6 \%\end{array}$ & $\begin{array}{c}1 \\
16.6 \%\end{array}$ & $\begin{array}{c}0 \\
0.00 \%\end{array}$ & $0.00 \%$ \\
\hline $\begin{array}{l}\text { Coordination among the various } \\
\text { departments during the school Term } \\
\text { improve academic performance }\end{array}$ & $33.4 \%$ & $66.6 \%$ & $0.00 \%$ & $0.00 \%$ & $0.00 \%$ \\
\hline $\begin{array}{l}\text { The management can be able to } \\
\text { overcome the challenges of budget } \\
\text { implementation }\end{array}$ & $50 \%$ & $33.4 \%$ & $16.6 \%$ & $0.00 \%$ & $0.00 \%$ \\
\hline
\end{tabular}

\section{Source: Researcher, 2021}

\section{Table 4.8 Influence of Financial Controls-Bursars/ Boards of Management Reps}

According to table 4.8 above, majority of the respondents with (50\%) strongly agreed that the institution issues budget guidelines prior to the preparation of the budget, $(66.6 \%)$ agreed that all the staff participate in the preparation of the budget and discussions within their departments, while $(66.6 \%)$ strongly agreed that Planning is important to the success of the students in examinations, (50\%) of the participants strongly agreed that there is proper communication during the process of teaching and learning, additionally ( 66.6\%) strongly agreed that support provided to the subordinate staff during the school Term is effective, $(66.6 \%)$ agreed that the coordination among the various departments during the school Term improve academic performance, and ( $50 \%$ ) of the participants strongly agreed that the management can be able to overcome the challenges of budget implementation. This implies that, planning is concerned with internal resource allocation to achieve certain objectives whereas control is concerned with the task of coordinating and using allocated resources to achieve predetermined levels of efficiency. It offers a number of control procedures such as communication, authorization of expenditure and performance evaluation (Moll, 2003).

\subsubsection{Challenges principals of public secondary schools face}

Challenges principals of public secondary schools face in the management of finance; using a rating scale of 1 to 5, please indicate (tick) the importance of the statement on the challenges facing students' academic performance.

\begin{tabular}{|c|c|c|c|c|c|}
\hline \multirow[t]{2}{*}{ Statement } & 5 & 4 & 3 & 2 & 1 \\
\hline & $\begin{array}{l}\text { Strongly } \\
\text { Agree }\end{array}$ & Agree & Neutral & Disagree & $\begin{array}{l}\text { Strongly } \\
\text { disagree }\end{array}$ \\
\hline $\begin{array}{l}\text { In some cases budget include unattainable } \\
\text { targets or standards }\end{array}$ & $\begin{array}{c}3 \\
50 \%\end{array}$ & $\begin{array}{c}1 \\
16.6 \%\end{array}$ & $\begin{array}{c}2 \\
33.4 \%\end{array}$ & $\begin{array}{c}0 \\
0.00 \%\end{array}$ & $\begin{array}{c}0 \\
0.00 \%\end{array}$ \\
\hline $\begin{array}{l}\text { Insufficient funds allocation affect the } \\
\text { implementation of the school programs }\end{array}$ & $\begin{array}{c}1 \\
16.6 \%\end{array}$ & $\begin{array}{c}3 \\
50 \%\end{array}$ & $\begin{array}{c}2 \\
33.4 \%\end{array}$ & $\begin{array}{c}0 \\
0.00 \%\end{array}$ & $\begin{array}{c}0 \\
0.00 \%\end{array}$ \\
\hline $\begin{array}{l}\text { Inability of departments to utilize the } \\
\text { allocated funds hinders the effective } \\
\text { teaching and learning }\end{array}$ & $\begin{array}{c}3 \\
50 \%\end{array}$ & $\begin{array}{c}2 \\
33.4 \%\end{array}$ & $\begin{array}{c}1 \\
16.6 \%\end{array}$ & $\begin{array}{c}0 \\
0.00 \%\end{array}$ & $\begin{array}{c}0 \\
0.00 \%\end{array}$ \\
\hline $\begin{array}{l}\text { The methods used to allocate funds to the } \\
\text { departments are unsatisfactory }\end{array}$ & $\begin{array}{c}0 \\
0.00 \% \\
\end{array}$ & $\begin{array}{c}1 \\
16.6 \%\end{array}$ & $\begin{array}{c}2 \\
33.4 \% \\
\end{array}$ & $\begin{array}{c}1 \\
16.6 \%\end{array}$ & $\begin{array}{c}2 \\
33.4 \% \\
\end{array}$ \\
\hline $\begin{array}{l}\text { Reforms in school financial management } \\
\text { come up with new rules which affect } \\
\text { students' academic performance }\end{array}$ & $\begin{array}{c}2 \\
33.4 \%\end{array}$ & $\begin{array}{c}1 \\
16.6 \%\end{array}$ & $\begin{array}{c}3 \\
50 \%\end{array}$ & $\begin{array}{c}0 \\
0.00 \%\end{array}$ & $\begin{array}{c}0 \\
0.00 \%\end{array}$ \\
\hline
\end{tabular}

\section{Source: Researcher, 2021}

Table 4.9 Challenges principals face - Bursars/ Boards of Management Reps 
Table 4.9 above shows that majority of the participants with (50\%) strongly agreed that in some cases budget include unattainable targets or standards, (50\%) agreed that insufficient funds allocation affect the implementation of the school programs, while $(50 \%)$ of the respondents strongly agreed that inability of departments to utilize the allocated funds hinders the effective teaching and learning, nevertheless ( $33.4 \%$ ) of the participants were neutral on their opinion concerning the methods used to allocate funds to the departments are unsatisfactory, and $(50 \%)$ of the respondents were also neutral on the statement that reforms in school financial management come up with new rules which affect students' academic performance. Therefore this states that, most principals faced a strong challenge by the board of management concerning financial resource which is often the source of conflict of interest. It is therefore imperative to find out the best ways of financial resource management in schools for optimum utilization of opportunities for excellent students' academic performance, Bennell and Sayed (2002). 
4.5 General Information - Heads of Departments/ Teachers

\# Heads of Departments/Teachers-Response: 35 participants

\begin{tabular}{|c|c|c|c|c|c|c|c|c|c|c|c|}
\hline Statement & Male & Female & $\begin{array}{l}\text { Below } 10 \\
\text { years }\end{array}$ & $\begin{array}{l}10-20 \\
\text { Years }\end{array}$ & $\begin{array}{l}21-30 \\
\text { years }\end{array}$ & $\begin{array}{c}3 \\
\text { months }\end{array}$ & $\begin{array}{c}6 \\
\text { months }\end{array}$ & 1 year & $\begin{array}{l}\text { More than } \\
1 \text { year }\end{array}$ & Yes & No \\
\hline $\begin{array}{l}\text { Worked in the } \\
\text { school? }\end{array}$ & $\begin{array}{c}5 \\
14.3 \%\end{array}$ & $\begin{array}{c}8 \\
22.8 \%\end{array}$ & $\begin{array}{c}6 \\
17.2 \%\end{array}$ & $\begin{array}{c}3 \\
8.6 \%\end{array}$ & $\begin{array}{c}2 \\
5.7 \%\end{array}$ & $\begin{array}{c}14 \\
40 \%\end{array}$ & $\begin{array}{c}0 \\
0.00 \%\end{array}$ & $\begin{array}{c}0 \\
0.00 \%\end{array}$ & $\begin{array}{c}0 \\
0.00 \%\end{array}$ & $\begin{array}{c}10 \\
28.6 \%\end{array}$ & $\begin{array}{c}0 \\
0.00 \%\end{array}$ \\
\hline Term schedule & $\begin{array}{c}2 \\
5.7 \%\end{array}$ & $\begin{array}{c}5 \\
14.3 \%\end{array}$ & $\begin{array}{c}4 \\
11.4 \%\end{array}$ & $\begin{array}{c}8 \\
22.8 \%\end{array}$ & $\begin{array}{c}0 \\
0.00 \%\end{array}$ & $\begin{array}{c}9 \\
25.7 \%\end{array}$ & $\begin{array}{c}0 \\
0.00 \%\end{array}$ & $\begin{array}{c}0 \\
0.00 \%\end{array}$ & $\begin{array}{c}0 \\
0.00 \%\end{array}$ & $\begin{array}{c}14 \\
40 \%\end{array}$ & $\begin{array}{c}2 \\
5.7 \%\end{array}$ \\
\hline $\begin{array}{l}\text { School } \\
\text { Administrator }\end{array}$ & $\begin{array}{c}6 \\
17.2 \%\end{array}$ & $\begin{array}{c}9 \\
25.7 \%\end{array}$ & $\begin{array}{c}6 \\
17.2 \%\end{array}$ & $\begin{array}{c}5 \\
14.3 \%\end{array}$ & $\begin{array}{c}1 \\
2.8 \%\end{array}$ & $\begin{array}{c}12 \\
34.3 \%\end{array}$ & $\begin{array}{c}0 \\
0.00 \%\end{array}$ & $\begin{array}{c}0 \\
0.00 \%\end{array}$ & $\begin{array}{c}0 \\
0.00 \%\end{array}$ & $\begin{array}{c}8 \\
22.8 \%\end{array}$ & $\begin{array}{c}1 \\
2.9 \%\end{array}$ \\
\hline Total & \multicolumn{2}{|c|}{35} & \multicolumn{3}{|c|}{35} & \multicolumn{4}{|c|}{35} & \multicolumn{2}{|c|}{35} \\
\hline Percentage & \multicolumn{2}{|c|}{$100 \%$} & \multicolumn{3}{|c|}{$100 \%$} & \multicolumn{4}{|c|}{$100 \%$} & \multicolumn{2}{|c|}{$100 \%$} \\
\hline
\end{tabular}

Source: Researcher, 2021

Table 4.10 General Information-Heads of Departments/ Teachers 
As shown in table 4.10 above, majority of the participants with (62.8\%) were female while their counterpart male with $(37.2 \%)$ respectively. Nevertheless, the researcher distributed questions about worked experiences in the school, majority of the respondents were below 10 years' experience with a percentage of (45.8\%), while (45.7) were between 10-20 years worked experiences, and (8.5\%) were between 21-30 years worked experiences. Furthermore, they were asked about the school term schedule and (100\%) of the participants said YES the school term schedule is 3 months respectively. Therefore, the researcher asked the participants about school administrators and $(91.4 \%)$ of the respondents said YES while, ( $8.6 \%)$ of the respondents said $\mathrm{NO}$, that the statement which says do you think the secondary school administrators get enough time to prepare for the task prior to their appointment.

Furthermore, the researcher interviewed the heads of departments and the teachers of the following schools; Karen 'C' Secondary School, Lang'ata High School, Lang'ata Barracks Secondary School, Olympic High School and Raila Educational Centre Secondary School, to understand how they are aware of the principal involvement in the preparation of the financial budget of the school. The following are the questions that distributed by the researcher; how is the school principal involved in the preparation of the budget?, how is the Board of Management involved in the budget process?, how is the Finance Committee involved in the process of budgeting? is there a finance policy in the school?, does it detail how the budget process should be followed?, how do you get information for the budget?, who reviews the budget before it is presented to the school board for approval?, would you say your school does pre- control, concurrent control and post control of the budget?, and how does the budget affect the academic performance in the school?. Therefore, the following are the statements by the participants;

"Indeed, the involvement of the principal in any given budget of the school; he/ she must be fully involved to make the work smoother and easier for the finance committee to conduct their business as usually. The board of management is always calls in by the principal in case of any mismanagement by the finance committee/ teachers or any given new plan by school organs, this where their fully involvement in the school activities. Good question; the finance committees involvement in budget processing is as a teacher involvement in a student academic performance. Indeed, the school has a fully planed finance policy, which is shared by finance committees to the schools organs in order to have all the school staff aware of the school timetable and programs. Yes, the finance policy schedule timetable shows how its runs by the school finance committee and other organs of the school.

The information for the budget is provided by the school finance committee and the top management. The reviews of the financial budget are reviewed by the finance committee before submitting to any school organs. Yes my school does pre- control, concurrent control and post -control of the budget frequently. When theirs is no good plan from the finance committee on how to review the term financial plan, many organs of the school frustrated and won't work peacefully and that cause a lot of interruptions in the ongoing classes, which will permit the students to perform badly in their academic results.

Source: Interviewers, 2021

Also the researcher asked the participants about how the school principal ensures that the schools expenditures are in line with the budgeted finance. Therefore, the questions as follows; how does the school principal ensure that the school's expenditure is in line with the budgeted finances?, is the school principal fully involved in the implementation of the school budget?, is the actual expenditure compared to the budgeted finances in the course of budget implementation?, how are variances in the budget identified?, how are they reported to the finance committee and the Board of Management (BOM)?, how are corrective measures taken when there are significant variances in the budget?, and how does effective financial management affect students' academic performance?. Therefore, the following thoughts were demonstrated by the participants during the interviews; 
"Through a full consultations to all staff by calling in for frequent meetings. Yes, the school principal is fully involved in any plans goes within the school environment. Well, somehow it's the financial reports for all the expenditures within the school. Most of the time variances in the budgeted finance are identified through a call in meeting and a panel of members who are experts in financial activities. They are reported through a secret panel that is run by the principal and other arm of the school to the finance committee and the board of management respectively. Sometimes they reach to a conclusion by dismissing the member that is fully involved in any variances in the school budget. The effective financial management does fully affect the student academic performance through, a failure or not implementing all the plans that was provided to the students by the board of management."

Source: Interviewers, 2021

Nevertheless, the researcher distributed the following questions to get the views of the participants concerning the actual expenditures of the school and how they go about it. The following are the questions; does actual expenditure sometimes exceed or fall far below from the budget?, how often does this happen?, what are the most common reasons for this?, how does the school principal contribute to the variances in the school budget?, how are budget variances corrected - such that they do not happen again?, what challenges do you experience in the implementation of the school budgetary allocations?, and do the challenges adversely affect the students' academic performance?. Therefore, the participants stated the following;

"Somehow, the actual expenditure falls due to lack of experts in the management. Once, having a wrong individual in the office. Misunderstanding by the board management or the finance committee. Most of the time by dismissing the fully involved individual in front of the board management and the finance committee. They are corrected through a call in meeting by the principal and the top management. Sometimes the board of management or the finance committee they don't fully involve the teachers or they don't ask for their opinion concerning the matter. Of course other teachers are well connected to students, so most of the time if their opinion or their not involved in any school activities they go to the class with a such emotion which will leads to teaching or unattainable to the syllabus which was given by the ministry of education, and that leads the teacher to teach unknown syllabus that will trauma the students not to perform well in the class, and which will lead them to lower academic performance respectively."

\section{Source: Interviewers, 2021}

Therefore, this implies that each member of the school must be given his/her mandate in the school fully in order to avoid any misconduct. Furthermore, the school financial committee through the Board of Management should be knowledgeable about: School balance sheets; the money that is needed and why it is needed; how and where to get the money needed; how the money will be spent; all the relevant members of the school on financial management; guidelines such as board of management, financial committee and heads of department; the purpose of a budget; the necessity of policy making; setting up of necessary structures e.g. Finance Committee, to take charge of finances; understanding and monitoring of dates important for different processes and putting monitoring mechanisms in place and reporting to parents and the involved committee, Bisschoff and Mestry (2007). 
Relationship between financial resource management and students' academic performance in public secondary schools in Lang'ata sub-county, Nairobi County: Therefore, financial resources have a number of purposes; indicate how important you think that each of the following is relevant; using a rating scale of 1 to 5 , please indicate (tick) the importance of the statement on the financial resource management and students' academic performance.

\begin{tabular}{|l|c|c|c|c|c|}
\hline \multicolumn{1}{|c|}{ Statement } & $\mathbf{5}$ & $\mathbf{4}$ & $\mathbf{3}$ & $\mathbf{2}$ & $\mathbf{1}$ \\
\cline { 2 - 6 } & $\begin{array}{c}\text { Strongly } \\
\text { agree }\end{array}$ & Agree & Neutral & Disagree & $\begin{array}{c}\text { Strongly } \\
\text { disagree }\end{array}$ \\
\hline $\begin{array}{l}\text { Financial resources are used to forecast the } \\
\text { future and therefore good for planning }\end{array}$ & 18 & 12 & 5 & 0 & 0 \\
& $51.4 \%$ & $34.3 \%$ & $14.3 \%$ & $0.00 \%$ & $0.00 \%$ \\
\hline $\begin{array}{l}\text { Financial resources are used to control other } \\
\text { resources }\end{array}$ & 10 & 8 & 13 & 3 & 1 \\
\hline $\begin{array}{l}\text { Budgets are used to communicate to other } \\
\text { levels in the departments }\end{array}$ & $22.8 \%$ & $22.8 \%$ & $37.3 \%$ & $8.6 \%$ & $2.8 \%$ \\
\hline $\begin{array}{l}\text { Financial resources are used to judge students' } \\
\text { academic performance }\end{array}$ & $2.7 \%$ & $14.3 \%$ & $34.3 \%$ & $17.2 \%$ & $28.5 \%$ \\
\hline $\begin{array}{l}\text { They are used to motivate employees to do } \\
\text { better }\end{array}$ & 12 & 16 & 3 & 1 & 4 \\
\hline
\end{tabular}

\section{Source: Researcher, 2021}

\section{Table 4.11 Influence of Budget Management- Heads of Departments/ Teachers}

Its evidence from table 4.11 above that, majority of the participants with (51.4\%) strongly agreed that financial resources are used to forecast the future and therefore good for planning, while (37.3\%) were neutral on the opinion that financial resources are used to control other resources, (40\%) were neutral also the statements which says that budgets are used to communicate to other levels in the departments, nevertheless $(34.3 \%)$ of the respondents were neutral on the said statement that financial resources are used to judge students' academic performance, and (45.7\%) agreed that they are used to motivate employees to do better. Therefore, this explains that the expense of accountability and transparency, discrepancies between Heads of department and teachers estimates and school investment programs, poor quality of plans due to poor targeting, high per unit costs and low completion rates, weak accounting systems, inadequate and at times lack of monitoring and evaluating systems and failure to develop management information systems that will gain all teachers trust in the school administration, Kiringai and West (2002).

\subsubsection{Influence of Financial Controls}

The extent to which financial resource management affect students' academic performance in public secondary schools in Lang'ata sub-county, Nairobi County: Using a rating scale of 1 to 5, please indicate (tick) the importance of the statement on the extent to which financial resource management affect students' academic performance.

\begin{tabular}{|c|c|c|c|c|c|}
\hline Statement & 5 & 4 & 3 & 2 & 1 \\
\cline { 2 - 5 } & $\begin{array}{c}\text { Strongly } \\
\text { Agree }\end{array}$ & Agree & Neutral & Disagree & $\begin{array}{c}\text { Strongly } \\
\text { Disagree }\end{array}$ \\
\hline
\end{tabular}




\begin{tabular}{|l|c|c|c|c|c|}
\hline $\begin{array}{l}\text { The institution issues budget guidelines } \\
\text { prior to the preparation of the budget }\end{array}$ & $\begin{array}{c}15 \\
\text { All the staff participate in the }\end{array}$ & $\begin{array}{c}12 \\
34.4 \%\end{array}$ & $\begin{array}{c}7 \\
20 \%\end{array}$ & $2.8 \%$ & $0.00 \%$ \\
\hline $\begin{array}{l}\text { All } \\
\text { preparation of the budget and } \\
\text { discussions within their departments }\end{array}$ & $14.4 \%$ & $22.8 \%$ & $45.7 \%$ & $11.4 \%$ & $5.7 \%$ \\
\hline $\begin{array}{l}\text { Planning is important to the success of } \\
\text { the students in examinations }\end{array}$ & 22 & 8 & 5 & 0 & 0 \\
\hline $\begin{array}{l}\text { There is proper communication during } \\
\text { the process of teaching and learning }\end{array}$ & $51.4 \%$ & $17.2 \%$ & $20 \%$ & $8.6 \%$ & $2.8 \%$ \\
\hline $\begin{array}{l}\text { Support provided to the subordinate } \\
\text { staff during the school Term is effective }\end{array}$ & $37.2 \%$ & $31.4 \%$ & $25.7 \%$ & $5.7 \%$ & $0.00 \%$ \\
\hline $\begin{array}{l}\text { Coordination among the various } \\
\text { departments during the school Term } \\
\text { improve academic performance }\end{array}$ & $65.7 \%$ & $34.3 \%$ & $0.00 \%$ & $0.00 \%$ & $0.00 \%$ \\
\hline $\begin{array}{l}\text { The management can be able to } \\
\text { overcome the challenges of budget } \\
\text { implementation }\end{array}$ & $57.2 \%$ & $42.8 \%$ & $0.00 \%$ & $0.00 \%$ & $0.00 \%$ \\
\hline
\end{tabular}

\section{Source: Researcher, 2021}

\section{Table 4.12 Influence of Financial Controls- Heads of Departments/ Teachers}

As illustrated by table 4.12 above, majority of the participants with (42.8\%) strongly agreed that The institution issues budget guidelines prior to the preparation of the budget, (45.7\%) of the respondents were neutral on the mater concerning; all the staff participate in the preparation of the budget and discussions within their departments, while (62.8\%) strongly agreed that planning is important to the success of the students in examinations, ( $51.4 \%$ ) strongly agreed that there is proper communication during the process of teaching and learning, additionally ( $37.2 \%$ ) strongly agreed that support provided to the subordinate staff during the school Term is effective, ( 65.7\%) strongly agreed that coordination among the various departments during the school Term improve academic performance, finally ( 57.2\%) strongly agreed that the management can be able to overcome the challenges of budget implementation. Therefore, this states that most school heads department and teachers are unable to learn about the school financial values and processes due to limited knowledge or lack of time to dedicate to these matters. Such an approach affects the overall performance of the school, especially the students' academic performance, Keith (2008).

\subsubsection{Challenges principals of public secondary schools face - Heads of Departments/ Teachers}

Challenges principals of public secondary schools face in the management of finance; using a rating scale of 1 to 5 , please indicate (tick) the importance of the statement on the challenges facing students' academic performance.

\begin{tabular}{|l|c|c|c|c|c|}
\hline \multicolumn{1}{|c|}{ Statement } & $\mathbf{5}$ & $\mathbf{4}$ & $\mathbf{3}$ & $\mathbf{2}$ & $\mathbf{1}$ \\
\cline { 2 - 6 } & $\begin{array}{c}\text { Strongly } \\
\text { Agree }\end{array}$ & Agree & Neutral & Disagree & $\begin{array}{c}\text { Strongly } \\
\text { disagree }\end{array}$ \\
\hline $\begin{array}{l}\text { In some cases budget include unattainable } \\
\text { targets or standards }\end{array}$ & 9 & 11 & 15 & 0 & 0 \\
\hline Insufficient funds allocation affect the & $25.7 \%$ & $31.5 \%$ & $42.8 \%$ & $0.00 \%$ & $0.00 \%$ \\
\hline
\end{tabular}




\begin{tabular}{|l|c|c|c|c|c|}
\hline implementation of the school programs & $80 \%$ & $20 \%$ & $0.00 \%$ & $0.00 \%$ & $0.00 \%$ \\
\hline $\begin{array}{l}\text { Inability of departments to utilize the } \\
\text { allocated funds hinders the effective } \\
\text { teaching and learning }\end{array}$ & $57.1 \%$ & $17.2 \%$ & $25.7 \%$ & $0.00 \%$ & $0.00 \%$ \\
\hline $\begin{array}{l}\text { The methods used to allocate funds to the } \\
\text { departments are unsatisfactory }\end{array}$ & 3 & 5 & 11 & 4 & 12 \\
\hline $\begin{array}{l}\text { Reforms in school financial management } \\
\text { come up with new rules which affect } \\
\text { students' academic performance }\end{array}$ & $20 \%$ & $14.3 \%$ & $28.6 \%$ & $11.4 \%$ & $25.7 \%$ \\
\hline
\end{tabular}

\section{Source: Researcher, 2021}

\section{Table 4.13 Challenges do principals face-Heads of Departments/ Teachers}

According to table 4.13 above, majority of the participants with $(42.8 \%)$ were neutral on the statement that says; in some cases budget include unattainable targets or standards, while (80\%) strongly agreed that insufficient funds allocation affect the implementation of the school programs, (57.1\%) strongly agreed that inability of departments to utilize the allocated funds hinders the effective teaching and learning, additionally (34.2\%) strongly disagreed that the methods used to allocate funds to the departments are unsatisfactory, and (28.6\%) were neutral on the opinion that says; reforms in school financial management come up with new rules which affect students' academic performance. Therefore, this implies that principals face the challenges of delayed disbursement of funds, hence slowing down school operations which in the long run affect the students' performance in general. Furthermore, it led to high completion rates among the disadvantaged students, Rok, (2008).

\subsection{General Information - Students}

\# Students - Response: 194 participants

\begin{tabular}{|c|c|c|c|c|c|c|c|c|c|c|c|c|}
\hline Statement & $\begin{array}{c}\text { Mal } \\
\mathrm{e}\end{array}$ & $\begin{array}{c}\text { Fema } \\
\text { le }\end{array}$ & $\begin{array}{c}3 \\
\text { mont } \\
\text { hs }\end{array}$ & $\begin{array}{c}6 \\
\text { mont } \\
\text { hs }\end{array}$ & $\begin{array}{c}1 \\
\text { year }\end{array}$ & $\begin{array}{l}\text { Mor } \\
\mathrm{e} \\
\text { than } \\
1 \\
\text { year }\end{array}$ & Yes & No & $\begin{array}{c}\text { Top } \\
\text { Manageme } \\
\text { nt }\end{array}$ & $\begin{array}{c}\text { Finance } \\
\text { Committee }\end{array}$ & $\begin{array}{l}\text { Finance } \\
\text { Manager }\end{array}$ & Principal \\
\hline $\begin{array}{l}\text { Term } \\
\text { schedule }\end{array}$ & $\begin{array}{l}16 \\
8.3 \\
\%\end{array}$ & $\begin{array}{c}30 \\
15.5 \\
\%\end{array}$ & $\begin{array}{c}38 \\
19.5 \\
\%\end{array}$ & $\begin{array}{c}2 \\
1.1 \%\end{array}$ & $\begin{array}{c}0 \\
0.00 \\
\%\end{array}$ & $\begin{array}{c}0 \\
0.00 \\
\%\end{array}$ & $\begin{array}{c}35 \\
18.1 \\
\%\end{array}$ & $\begin{array}{c}7 \\
3.6 \\
\%\end{array}$ & $\begin{array}{c}24 \\
12.4 \%\end{array}$ & $\begin{array}{c}13 \\
6.7 \%\end{array}$ & $\begin{array}{c}6 \\
3.1 \%\end{array}$ & $\begin{array}{c}55 \\
28.4 \%\end{array}$ \\
\hline $\begin{array}{l}\text { School } \\
\text { Administr } \\
\text { ator }\end{array}$ & $\begin{array}{c}38 \\
19.5 \\
\%\end{array}$ & $\begin{array}{c}54 \\
27.8 \\
\%\end{array}$ & $\begin{array}{c}88 \\
45.5 \\
\%\end{array}$ & $\begin{array}{c}0 \\
0.00 \\
\%\end{array}$ & $\begin{array}{c}1 \\
0.5 \\
\%\end{array}$ & $\begin{array}{c}0 \\
0.00 \\
\%\end{array}$ & $\begin{array}{c}47 \\
24.2 \\
\%\end{array}$ & $\begin{array}{c}8 \\
4.1 \\
\%\end{array}$ & $\begin{array}{c}19 \\
9.8 \%\end{array}$ & $\begin{array}{c}3 \\
1.5 \%\end{array}$ & $\begin{array}{c}2 \\
1.1 \%\end{array}$ & $\begin{array}{c}13 \\
6.7 \%\end{array}$ \\
\hline $\begin{array}{l}\text { Final } \\
\text { Decision } \\
\text { maker }\end{array}$ & $\begin{array}{c}22 \\
11.4 \\
\%\end{array}$ & $\begin{array}{c}34 \\
17.5 \\
\%\end{array}$ & $\begin{array}{c}64 \\
32.9 \\
\%\end{array}$ & $\begin{array}{c}1 \\
0.5 \%\end{array}$ & $\begin{array}{c}0 \\
0.00 \\
\%\end{array}$ & $\begin{array}{c}0 \\
0.00 \\
\%\end{array}$ & $\begin{array}{c}88 \\
45.4 \\
\%\end{array}$ & $\begin{array}{c}9 \\
4.6 \\
\%\end{array}$ & $\begin{array}{c}19 \\
9.8 \%\end{array}$ & $\begin{array}{c}9 \\
4.6 \%\end{array}$ & $\begin{array}{c}3 \\
1.5 \%\end{array}$ & $\begin{array}{c}28 \\
14.4 \%\end{array}$ \\
\hline Total & \multicolumn{2}{|c|}{194} & \multicolumn{4}{|c|}{194} & \multicolumn{2}{|c|}{194} & \multicolumn{4}{|c|}{194} \\
\hline $\begin{array}{l}\text { Percentag } \\
\text { e }\end{array}$ & \multicolumn{2}{|c|}{$100 \%$} & \multicolumn{4}{|c|}{$100 \%$} & \multicolumn{2}{|c|}{$100 \%$} & \multicolumn{4}{|c|}{$100 \%$} \\
\hline
\end{tabular}

Source: Researcher, 2021

Table 4.14 General Information - Students 
Its evidence as illustrated by table 4.14 above, that majority of the respondents with $(60.8 \%)$ were female while their counterpart male with (39.2\%) respectively. Nevertheless, the researcher asked the participants about term schedule of the school, and (97.9\%) strongly agreed that the term schedule of the school is 3 months period, while (1.6\%) said that its 6 months, and $(0.5 \%)$ said that is 1 year. Additionally the researcher asked the participants about the school administrators and they said as follows with (87.7\%) said that they think the secondary school administrators get enough time to prepare for the task prior to their appointment, while ( $12.3 \%$ ) think that the school administrators don't have enough time to prepare for the task prior to their appointments. Finally the researcher asked the respondents that who is the final decision maker in the school: majority of the participants with (49.5\%) think that the final decision maker in the school is the principal, while (32\%) think is the top management, $(12.8 \%)$ think that the finance committee is the final decision maker in the school, and (5.7\%) think that it's the finance managers who make the final decision in the school.

Nevertheless, the researcher had a chance to ask the students about how they can add more additional comments on the relationship between the financial resource management and the student's academic performance in public secondary schools. Therefore, their comments were as follows;

"Studying in a public secondary school has advantages and disadvantages; looking on the side of disadvantages it is a very big challenge to us as students. On other side of the financial resource management and its effects on student academic performance, it's about how we get to pay the school fees, and that we face a challenge as some students come to public because it's affordable for some of us. Additionally, financial resources are very essential in student's performance in public secondary school. Where there is adequate finance, the school will improve academically due to availability of the resources provided by finance. So the public secondary school should be provided with financial resource at any given time."

Source: Interviewers, 2021

Therefore, this explains that effective school financial resource management is brought about by clear long term plans and priorities. It is important that clear plans for spending the limited funds are drawn. Therefore, it is expected that for this study, budget participation would enhance the financial management of the schools and the students' academic performance respectively. On the other hand, there is a close relationship between parent's occupation and children's academic outcome. Parents with relatively high incomes are likely to support their children's education hence motivating them to achieve better grades in school at all times, Ogunshola and Adewale (2012).

\subsubsection{Influence of Budget Management}

Relationship between financial resource management and students' academic performance in public secondary schools in Lang'ata sub-county, Nairobi County: Therefore, financial resources have a number of purposes; indicate how important you think that each of the following is relevant; using a rating scale of 1 to 5 , please indicate (tick) the importance of the statement on the financial resource management and students' academic performance.

\begin{tabular}{|c|c|c|c|c|c|}
\hline \multirow[t]{2}{*}{ Statement } & 5 & 4 & 3 & 2 & 1 \\
\hline & $\begin{array}{c}\text { Strongly } \\
\text { agree }\end{array}$ & Agree & Neutral & Disagree & $\begin{array}{l}\text { Strongly } \\
\text { disagree }\end{array}$ \\
\hline $\begin{array}{l}\text { Financial resources are used to forecast the } \\
\text { future and therefore good for planning }\end{array}$ & $\begin{array}{c}92 \\
47.4 \%\end{array}$ & $\begin{array}{c}66 \\
34 \%\end{array}$ & $\begin{array}{c}28 \\
14.4 \%\end{array}$ & $\begin{array}{c}2 \\
1.1 \%\end{array}$ & $\begin{array}{c}6 \\
3.1 \%\end{array}$ \\
\hline
\end{tabular}




\begin{tabular}{|c|c|c|c|c|c|}
\hline $\begin{array}{l}\text { Financial resources are used to control other } \\
\text { resources }\end{array}$ & $\begin{array}{c}89 \\
45.8 \%\end{array}$ & $\begin{array}{c}23 \\
11.8 \%\end{array}$ & $\begin{array}{c}82 \\
42.4 \%\end{array}$ & $\begin{array}{c}0 \\
0.00 \%\end{array}$ & $\begin{array}{c}0 \\
0.00 \%\end{array}$ \\
\hline $\begin{array}{l}\text { Budgets are used to communicate to other } \\
\text { levels in the departments }\end{array}$ & $\begin{array}{c}58 \\
29.8 \%\end{array}$ & $\begin{array}{c}77 \\
39.7 \%\end{array}$ & $\begin{array}{c}47 \\
24.3 \%\end{array}$ & $\begin{array}{c}10 \\
5.2 \%\end{array}$ & $\begin{array}{c}2 \\
1 \%\end{array}$ \\
\hline $\begin{array}{l}\text { Financial resources are used to judge } \\
\text { students' academic performance }\end{array}$ & $\begin{array}{c}25 \\
12.9 \%\end{array}$ & $\begin{array}{c}31 \\
15.9 \%\end{array}$ & $\begin{array}{c}38 \\
19.6 \%\end{array}$ & $\begin{array}{c}36 \\
18.7 \%\end{array}$ & $\begin{array}{c}64 \\
32.9 \%\end{array}$ \\
\hline $\begin{array}{l}\text { They are used to motivate employees to do } \\
\text { better }\end{array}$ & $\begin{array}{c}58 \\
29.9 \%\end{array}$ & $\begin{array}{c}45 \\
23.2 \%\end{array}$ & $\begin{array}{c}78 \\
40.2 \%\end{array}$ & $\begin{array}{c}8 \\
4.2 \%\end{array}$ & $\begin{array}{c}5 \\
2.5 \%\end{array}$ \\
\hline
\end{tabular}

\section{Source: Researcher, 2021}

\section{Table 4.15 Influence of Budget Management-Students}

According to table 4.15 above, majority of the participants with $(47.7 \%)$ strongly agreed that financial resources are used to forecast the future and therefore good for planning, (45.8\%) strongly agreed that Financial resources are used to control other resources, while (39.7\%) agreed that budgets are used to communicate to other levels in the departments, additionally ( $32.9 \%$ ) strongly disagreed that financial resources are used to judge students' academic performance, and (40.2\%) were neutral on their opinion concerning the statement that they are used to motivate employees to do better. Therefore, this shows that school financial management strategies and skills reflect the level of outcome in terms of students' academic performance, especially in this study, Birimana and Orodho (2014).

\subsubsection{Influence of Financial Controls}

The extent to which financial resource management affect students' academic performance in public secondary schools in Lang'ata sub-county, Nairobi County: Using a rating scale of 1 to 5, please indicate (tick) the importance of the statement on the extent to which financial resource management affect students' academic performance.

\begin{tabular}{|c|c|c|c|c|c|}
\hline \multirow[t]{2}{*}{ Statement } & 5 & 4 & 3 & 2 & 1 \\
\hline & $\begin{array}{l}\text { Strongly } \\
\text { Agree }\end{array}$ & Agree & Neutral & Disagree & $\begin{array}{l}\text { Strongly } \\
\text { Disagree }\end{array}$ \\
\hline $\begin{array}{l}\text { The institution issues budget guidelines } \\
\text { prior to the preparation of the budget }\end{array}$ & $\begin{array}{c}36 \\
18.6 \%\end{array}$ & $\begin{array}{c}66 \\
34 \%\end{array}$ & $\begin{array}{c}92 \\
47.4 \%\end{array}$ & $\begin{array}{c}0 \\
0.00 \%\end{array}$ & $\begin{array}{c}0 \\
0.00 \%\end{array}$ \\
\hline $\begin{array}{l}\text { All the staff participate in the } \\
\text { preparation of the budget and } \\
\text { discussions within their departments }\end{array}$ & $\begin{array}{c}52 \\
26.8 \%\end{array}$ & $\begin{array}{c}39 \\
20.3 \%\end{array}$ & $\begin{array}{c}88 \\
45.3 \%\end{array}$ & $\begin{array}{c}6 \\
3 \%\end{array}$ & $\begin{array}{c}9 \\
4.6 \%\end{array}$ \\
\hline $\begin{array}{l}\text { Planning is important to the success of } \\
\text { the students in examinations }\end{array}$ & $\begin{array}{c}112 \\
57.7 \%\end{array}$ & $\begin{array}{c}80 \\
41.3 \%\end{array}$ & $\begin{array}{c}2 \\
1 \%\end{array}$ & $\begin{array}{c}0 \\
0.00 \%\end{array}$ & $\begin{array}{c}0 \\
0.00 \%\end{array}$ \\
\hline $\begin{array}{l}\text { There is proper communication during } \\
\text { the process of teaching and learning }\end{array}$ & $\begin{array}{c}96 \\
49 \%\end{array}$ & $\begin{array}{c}2 \\
1 \%\end{array}$ & $\begin{array}{c}92 \\
48 \%\end{array}$ & $\begin{array}{c}4 \\
2 \%\end{array}$ & $\begin{array}{c}0 \\
0.00 \%\end{array}$ \\
\hline $\begin{array}{l}\text { Support provided to the subordinate } \\
\text { staff during the school Term is effective }\end{array}$ & $\begin{array}{c}60 \\
30.9 \%\end{array}$ & $\begin{array}{c}35 \\
18.04 \%\end{array}$ & $\begin{array}{c}77 \\
39.6 \%\end{array}$ & $\begin{array}{c}18 \\
9.4 \%\end{array}$ & $\begin{array}{c}4 \\
2.06 \%\end{array}$ \\
\hline
\end{tabular}




\begin{tabular}{|l|c|c|c|c|c|}
\hline $\begin{array}{l}\text { Coordination among the various } \\
\text { departments during the school Term } \\
\text { improve academic performance }\end{array}$ & $58.7 \%$ & $41.3 \%$ & $0.00 \%$ & $0.00 \%$ & $0.00 \%$ \\
\hline $\begin{array}{l}\text { The management can be able to } \\
\text { overcome the challenges of budget } \\
\text { implementation }\end{array}$ & $64.5 \%$ & $30.9 \%$ & $4.6 \%$ & $0.00 \%$ & $0.00 \%$ \\
\hline
\end{tabular}

\section{Source: Researcher, 2021}

\section{Table 4.16 Influence of Financial Controls-Students}

Table 4.16 shows that majority of the respondents with $(47.4 \%)$ were neutral on the said statement that the institution issues budget guidelines prior to the preparation of the budget, while (45.3\%) were neutral on the following statement that all the staff participate in the preparation of the budget and discussions within their departments, (57.7\%) strongly agreed that planning is important to the success of the students in examinations, (49\%) strongly agreed that there is proper communication during the process of teaching and learning, additionally (39.6\%) were neutral on the concerned opinion that says; support provided to the subordinate staff during the school Term is effective, (58.7\%) strongly agreed that coordination among the various departments during the school Term improve academic performance, and ( $64.5 \%)$ strongly agreed that the management can be able to overcome the challenges of budget implementation. Therefore, this implies that students lack basic management and financial skills by school development committees, Wushe, Ndlovu and Shenje (2014).

\subsubsection{Challenges principals of public secondary schools face - Students}

Challenges principals of public secondary schools face in the management of finance; using a rating scale of 1 to 5, please indicate (tick) the importance of the statement on the challenges facing students' academic performance.

\begin{tabular}{|c|c|c|c|c|c|}
\hline \multirow[t]{2}{*}{ Statement } & 5 & 4 & 3 & 2 & 1 \\
\hline & $\begin{array}{l}\text { Strongly } \\
\text { Agree }\end{array}$ & Agree & Neutral & Disagree & $\begin{array}{l}\text { Strongly } \\
\text { disagree }\end{array}$ \\
\hline $\begin{array}{l}\text { In some cases budget include unattainable } \\
\text { targets or standards }\end{array}$ & $\begin{array}{c}34 \\
17.5 \%\end{array}$ & $\begin{array}{c}10 \\
5.2 \%\end{array}$ & $\begin{array}{c}150 \\
77.3 \%\end{array}$ & $\begin{array}{c}0 \\
0.00 \%\end{array}$ & $\begin{array}{c}0 \\
0.00 \%\end{array}$ \\
\hline $\begin{array}{l}\text { Insufficient funds allocation affect the } \\
\text { implementation of the school programs }\end{array}$ & $\begin{array}{c}190 \\
97.9 \% \\
\end{array}$ & $\begin{array}{c}4 \\
2.1 \% \\
\end{array}$ & $\begin{array}{c}0 \\
0.00 \% \\
\end{array}$ & $\begin{array}{c}0 \\
0.00 \% \\
\end{array}$ & $\begin{array}{c}0 \\
0.00 \% \\
\end{array}$ \\
\hline $\begin{array}{l}\text { Inability of departments to utilize the } \\
\text { allocated funds hinders the effective } \\
\text { teaching and learning }\end{array}$ & $\begin{array}{c}12 \\
6.2 \%\end{array}$ & $\begin{array}{c}60 \\
30.9 \%\end{array}$ & $\begin{array}{c}115 \\
59.4 \%\end{array}$ & $\begin{array}{c}6 \\
3 \%\end{array}$ & $\begin{array}{c}1 \\
0.5 \%\end{array}$ \\
\hline $\begin{array}{l}\text { The methods used to allocate funds to the } \\
\text { departments are unsatisfactory }\end{array}$ & $\begin{array}{c}30 \\
15.5 \%\end{array}$ & $\begin{array}{c}36 \\
18.5 \% \\
\end{array}$ & $\begin{array}{l}128 \\
66 \%\end{array}$ & $\begin{array}{c}0 \\
0.00 \%\end{array}$ & $\begin{array}{c}0 \\
0.00 \%\end{array}$ \\
\hline $\begin{array}{l}\text { Reforms in school financial management } \\
\text { come up with new rules which affect } \\
\text { students' academic performance }\end{array}$ & $\begin{array}{c}160 \\
82.5 \%\end{array}$ & $\begin{array}{c}30 \\
15.5 \%\end{array}$ & $\begin{array}{c}4 \\
2 \%\end{array}$ & $\begin{array}{c}0 \\
0.00 \%\end{array}$ & $\begin{array}{c}0 \\
0.00 \%\end{array}$ \\
\hline
\end{tabular}

\section{Source: Researcher, 2021}

\section{Table 4.17 Challenges do principals face-Students}

As shown by table 4.17 above, majority of the participants with $(77.3 \%)$ were neutral on the statement that says; in some cases budget include unattainable targets or standards, (97.9\%) strongly agreed that insufficient funds allocation affect the implementation of the school programs, while ( 59.4\%) were neutral on the matter that says; inability of departments to utilize the allocated funds hinders the effective teaching and learning, additionally ( $66 \%$ ) of the participants were also neutral on the opinion that says; the methods used to allocate funds to the departments are unsatisfactory, and ( $82.5 \%)$ strongly agreed that reforms in 
school financial management come up with new rules which affect students' academic performance. Therefore, this implies that some principals face a lot of challenges as the head of school, especially in budget allocation or financial flows. According to Jajo (2005), controls in general involve authorization, segregation of duties, record keeping, safeguarding and reconciliation.

\subsection{Chapter summary}

The ideal or the concept of financial resources management and its influence on student's academic performance in public secondary schools has been a big issue in today's societies, especially during this pandemic (covid19) which has challenged the whole world to live under financial crisis. Therefore, this study revealed that financial resources management can truly affect student's academic performance. Furthermore, the researcher found out that not all staffs are involved in budget making or financial plans of the schools. Additionally, the researcher found out that most students are suffering due to lack of finances by their parents and guardians. Finally, financial stability goes hand in hand with educational success. Truly all teachers and staff need full adequate finances in order to ensure that the school's programs run smoothly and with ease for all. Also the researcher found out that most students studying in public schools have fees challenges, especially those in the slums like Kibera constituency - Lan'gata Sub County. Such acute financial challenges sometimes force them to drop out of school or to look for part time jobs, in order to pay for their schools fees. Therefore, financial crisis leads to students' lower academic performance, especially among the slum dwellers, in the reality of today's pandemic (covid19) which has made it more difficult for students to report back to schools.

\section{Summary Of Findings, Conclusion And Recommendations}

\subsection{Introduction}

This chapter five deals with the summary of the findings, conclusion and recommendations of the study. The overall goal of the study was to examine the Financial Resource Management and its Influence on Students Academic Performance in Public Secondary Schools in Lang'ata Sub-County, Nairobi County-Kenya. The study adopted descriptive survey design and targeted the affected students with financial challenges and its influence on student's academic performance in public secondary schools, principals, Bursars, Boards of Management Representatives, Heads of Departments, Teachers, and Students through random and purposive sampling. Therefore, primary data was collected using self-administered questionnaires and analyzed using descriptive statistics and presented in form of graphs and tables. This chapter discusses the summary of findings, conclusion and recommendations.

\subsection{Summary of the Findings}

\subsubsection{Influence of Budget Management}

The influence of budget management and resource management strategy is the efficient and effective deployment of an organization's resources when they are needed, and are very critical to enhanced academic performance in schools, especially in public secondary schools. Therefore, most principals agreed that financial resources are used to control other resources; nevertheless majority of them strongly agreed that Budgets are used to communicate to other levels in the departments. Finally, this implies that, the management of resources "financial resource management" in the institutions of learning eg. Secondary schools, plays a central role to achieve desirable outcomes of the institution. Additionally, Bursars and Boards of Management Representatives, Heads of Departments, Teachers Representatives and Students Representatives shows a similar opinion that majority of the participants think that budgets are used to communicate to other resource management in their respective areas. Most financial management skills involve the allocation of resources and the setting of targets, expectations and priorities. The main financial skills required by all school managers to enable them perform their duties successfully are budgeting, budget management and management of costs. 


\subsubsection{Influence of Financial Controls}

The concept of influence of financial control has backed to the technical details of school financial management reports presented to them while most school board members are unable to learn about the school financial values and processes due to limited knowledge or lack of time to dedicate to these matters. Principals, Bursars and Boards of Management Representatives, Heads of Departments and Teachers Representatives, Students Representatives, demonstrated their opinions as follows; Therefore, participants strongly agreed that the institution issues budget guidelines prior to the preparation of the budget and fully strongly agreed that all the staff participate in the preparation of the budget and discussions within their departments, while some of the participants strongly agreed that planning is important to the success of the students in examinations. This shows that, financial management or influence of financial controls in public secondary schools are concerned with defining the goals, and developing programs that will insure the convert such as goals into monetary values at all times. Finally, planning is concerned with internal resource allocation to achieve certain objectives whereas control is concerned with the task of coordinating and using allocated resources to achieve predetermined levels of efficiency.

\subsubsection{Challenges principals face}

Worldwide, secondary schools principal or education mangers are faced with challenges of change which are happening globally at a fast peace due to the advancement in today technology. On the other hand, such challenges are bound to test the abilities of secondary schools principals or education managers than people at any other level everywhere. Therefore, the findings shows that Principals, Bursars and Boards of Management Representatives, Heads of Departments, Teachers Representatives and Students Representatives strongly agreed that secondary schools principals faced a big challenge running the school with a less expertise. Furthermore they also agreed that they must be involved in any decision making in the school. On other hand, school principals, in the management of financial and other resources, have been given attention through various legislations, policies, moral as well as material support. Nevertheless, they also strongly agreed that secondary school principals faced challenges of handling students and staff at once without consultation from the top management and heads department, which sometimes leads to poor academic performance of the students. Therefore, this implies that, the management of resources, especially financial resource management in the institutions of learning such as secondary schools, plays a significant role in the achievement of desirable outcomes of the institution through the involvement of the school principals.

\subsection{Conclusion}

Around the world, many scholars have suggested and concluded that a similar study with the aim of improving academic performance; the relationship between financial resource management and students' academic performance should be explored further. Moreover, with insight in understanding the relationship between financial resource management and performance in institutions, school managers are constantly exploring ways to better educate students and improve school performance. Principals, Bursars, Boards of Management Representatives, Heads of Departments, Teachers Representatives and Students Representatives, came out clearly on the relationship between financial resource management and students' academic performance. Therefore, the study found out that the relationship between financial resource management and students' academic performance is a big challenge in today's society, especially during this pandemic (covid19) and its effects on education and the new normal of financial crisis. On the other hand, the pandemic (covid19) and the financial crisis have developed a critical phenomenon on the student's academic performance in today world due to the recourse to online learning and less learner - teacher contact.

Finally, the scholar or the founder of this topic has discovered from the findings that not all staff or secondary school teachers are well involved in budget making or in the financial plans drafted by the school board of management or the financial committee of the school. Also, the researcher found out that most of the public secondary schools students are suffering due to lack of finances, inadequate time for teaching, and availability of their parents and guardians on side. Financial stability goes hand in hand with education 
success. Truly all teachers, staffs of the schools need full adequate finances to ensure that the school programs run smoothly and with ease for all. Also the researcher found out most students studying in public secondary schools face lack of fees challenges, especially those in the slums like Kibera constituency, where the majority face a lot of financial constraints, which sometimes force them to drop out of school or to look for part time jobs, in order to pay for schools fees.

\subsection{Recommendations}

The study recommends that public secondary schools which are run by one Principal through centralized effort, should adopt team approach, by giving chance to all relevant organs of the school to perform their duties freely without any distraction unless it's a consultation needed by the appointed authority.

The study recommends that all Bursars and Boards of Management Representatives should be appointed with their merit certificate to the specific spot of the work in order to avoid any corruption in the field of their duties within the school environment.

The study recommends that Heads of Departments and Teachers, should be treated equally in all aspects of teaching, especially they should be given all the school's plans and activities for them to have full attention while teaching the students.

The study recommends that Students, should be provided with adequate teaching/learning materials; the teachers, heads of departments, finance committee, top management and the principal should treat the students fully as learners, and they should not dismiss any student from the school due to lack of fees; they should also provide counselling/ social workers departments to check on the students welfare and their mental problems regularly. Furthermore, the government should facilitate, in collaboration with parents, civil society and stakeholders, to provide full scholarship for all the needy students, especially the slum dwellers of Kibera constituency, in order for them not to lose hope in education.

\subsection{Suggestion for Further Studies}

Another study should be conducted on the same topic: financial resource management and its influence on student's academic performance in private secondary schools in Lang'ata sub-county, Nairobi countyKenya: to find out whether there are similarities in the findings of the study between public secondary schools and private secondary schools.

\section{Acknowledgement}

First, I thank the Almighty God for inspiring me to identify the grey areas in resource management and its influence on students' academic performance in public Secondary Schools in Lang'ata Sub-County, hence the need for conducting this research.

Special appreciation goes to the HoD, Faculty of Education at the Catholic University of Eastern Africa (CUEA), Sr. Professor Marcela Momanyi, Sr. Dr. Elizabeth Piliyesi who supported me during the initial stages, my supervisors, Sr. Dr. Elizabeth Nduku, and Dr. Jared Anyona Ntabo for their encouragement to begin in good time, the process of coming up with a thesis proposal. Their inspiration and guidance during and after lectures enabled me to complete this work.

Further acknowledgement goes to Bakanja College (AMECEA) staff and students for their support and prayers during my studies at CUEA. Special thanks to Fr. Peter Moudie, the Rector, Fr. John Mugo, the Vice Rector and Fr. Terry Omen, the General Spiritual Director for allowing me to stay in the Seminary and to use their facilities. I wish to thank all my friends for their helpful discussions and encouragement during the time of developing the proposal. To all, I say thank you.

\section{References}

1. Abend, G. (2008). The Meaning of Theory. Sociological Theory 26 (June 2008): 173 - 199; 
2. Abernethy M.A, \& Brownell O,(1999).The role of budgets in organizations facing strategic change, an exploratory study, Accounting Organization and society (24) pp189-204

a. Administration of Public Secondary Schools. International Journal of Scientific Research in Education,11(3B), 545-576. Retrieved [6 ${ }^{\text {th }}$ Dec.2019] from http://www.ijsre.com.

3. Akpakwu, S.O. (1996). The principal and the accounting system. The Voice, Monday Sept 19.

4. Akpakwu, S.O. (2008). Essentials of educational management. Makurdi: Jalin Press Ltd.

5. Amirize, M., \& Ololube, N. P. (2018). Principals Fund Management Strategies for Effective

6. Aringo (1987), The report of Education, Education Research Publication

7. Asemah, J.I. (2010). Perspectives in educational management and administration. Makurdi: Chris Publishers.

8. Bilkisu Bashir Aliyu. Assessment of Financial Management Practices Among Secondary School Principals Kaduna State. International Journal of Hospitality \& Tourism Management. Vol. 2, No. 2, 2018, pp. 22-27. doi: 10.11648/j.ijhtm.20180202.11

9. Bisschoff,T. \& Mestry, R. 2007. Financial school management explained. 2nd Ed. Cape Town: Maskew Miller.

10. Bozeman B., \& Strausman J.D, (1982).Public Administration Review, ( 42)

11. Bridgemohan, R. R. (2002). Parent involvement in early childhood development in Kwa-Zulu Natal. Unpublished doctoral dissertation. Johannesburg: University of South Africa.

12. Bua, F.T., Adzongo, P.I. (2014).Impact of financial management on secondary school's administration in zone a senatorial district of Benue State-Nigeria.Public Policy and Administration Research, 4(9), 95-103. Budget theory.Public Administration Review 42, 509-515.

13. Burke R.J. (2001) Effective Cash Management for schools: The Budget as a Control Document, Finance Momentum, Vol. 9 (4) pp. 16-19.

14. Chatiza,J.C. (2011). Introduction to Education Promoting Equality in Primary Schools. London: Casel.

15. Colander, D. (2013). Microeconomics, 9th edition, New York: McGraw Hill

16. Commonwealth Secretariat, (1996): Managing and motivating teachers under severe resource constraints: Training Principals to Face the Challenges, London: Commonwealth Secretariat.

17. Creswell, J. W. (2009). Research design: qualitative, quantitative and mixed methods approaches. Thousand Oaks, California: Sage Publications.

18. Crouch, L.,Winkler, D., \& RTI International. (2008). Governance, Management and Financing of Education for All: Basic Frameworks and Case Studies. Paris: UNESCO.

19. District Education Officers' report, Kitui District of (2009) on Principals' performance appraisal.

20. Eshiwani, G. (2009) National examinations, Nairobi: Government Printers.

21. Frederick, D, (2010). Control, Credit Management: Institute of Credit Management Ltd. Location of Lang'ata. Google Maps (2013) Retrieved on 3 February 2015 from https://en.wikipedia.org/wiki/google

22. G.O.K (2006) A handbook of financial management, Nairobi; government printer.

23. Globefeed.com, "Travel Distance between Nairobi Central Business District And Lang'ata With Map" Retrieved on 3 February 2015 from https://en.wikipedia.org/wiki/google

24. GoK (2007). Sessinal paper No. 1 of 2007 on policy Frame Work, Resource Management Training and Research.

25. Government of Kenya. (2013). The Basic Education Act, No. 13 of 2013. Nairobi: The Government Printer.

a. Hague: Ministry of Foreign Affairs.

26. Hanson, J.B. (2000). Student performance and student growth as measure of success: A evaluator's perspective. Paper presented at annual meeting of the American educational research association New Orleans. Louisiana. 25 April.

27. Hijazi, S.T. and Naqvi, S.M.M.R. (2006). Factor Affecting Students' Performance: A case of Private Colleges. Bangladesh e-journal of Sociology,3(1).

28. Hubbard, P. (2007). Putting the Power of Transparency in Context: Information's Role in

29. IOB (2008). Primary Education in Uganda: IOB Impact Evaluation no 311. April 2008. The 
30. Kapur R. (2018), Factors Influencing the Student's Academic Performance in Secondary Schools in India: University of Delhi

31. Khumalo, R. (2001). Understandable financial management: a guide for students and practitioners. Sandton: New Africa Books.

32. Kremer, K. P., Flower, A., Huang, J., \& Vaughn, M. G. (2016). Behaviour problems and children's academic achievement: A test of growth-curve models with gender and racial differences. Children and youth services review, 67, 95-104. doi:10.1016/j.childyouth.2016.06.003.

33. Kwaghbo, M. T. (2008). Fundamentals of financial management in education. Makurdi: Chris and Chris publishers.

34. Lamb, R. (2013). How can Managers Use Participative Leadership Effectively?

35. Lewis, P., Goodman, S. \& Fandt, P. (2004). Management challenges in the 21st century. Garland: Trinity Books.

36. Mawathe C.M, (2008). A survey of operational budgeting challenges the insurance industry in Kenya, University of Nairobi, School of Business.

37. Mestry, R. 2004. Financial accountability, the principal or the school governing body. South African Journal of Education, 24(2):126-132.

38. Mgbodile, T. O. (2002). Foundation in educational management and planning. Enugu: Magnet business Enterprise Routledge.

39. Ministry of Education, (2008). Guidelines for implementation of free secondary education. Nairobi: Government Printer.

40. Mobegi, F., Ondigi B., \&Simatwa, E. (2012). Factors Contributing to financial mismanagement and misappropriation in public Secondary Schools in Gucha District, Kenya,

41. Muhindi, D., (2012). Challenges facing the implementation of free day secondary education: A case study of Nyeri South District, Nyeri County in Kenya. Kenyatta University, Nairobi.

42. Muthinji E.M, (2009).Challenges of budget implementation in public sector organizations, a Case study of the Commissioner of Higher Education in Kenya, University of Nairobi, School of business.

43. Muthoki, M.M., (2015). Home based factors contributing to dropout of girls in mixed day secondary schools in Mtito-Andei division Kibwezi Sub-County Makueni County. Unpublished MEd Project, South Eastern Kenya University Kitui.

44. Mwenda A.K, Gachocho M.N, (2003).Budget Transparency Kenyan Perspective IEA Research Paper series no. 4 Nairobi County Integrated Development Plan, 2014

45. Ogbonnaya, N. I. (2000). Foundation of education finance. Onitsha: CAP Publishers

46. Okwori, A. (2004). Practical approach to educational planning. Makurdi: Peach Global Publications.

47. Olembo. J. O. (2005), Financing secondary education in Kenya. Nairobi: Bureau of Education Research.

48. Onuko, A.J., 2012. Impact of bursary schemes on retention of student sin Public Secondary Schools in Gem District, Kenya. Unpublished MEd Thesis, University of Nairobi, Nairobi.

49. Orodho, A.J., (2014). Financing basic education: What are the equity and quality implication of free primary education and free day secondary education policies in Kenya? International Journal of Development Research, 4(3): 477 - 487.

50. Paisley, A. (1992). Organization and management in schools. New York: America Manhattan Institute.

a. Reducing Corruption in Uganda's Education Sector. Working Paper Number 136

51. Republic of Kenya, (2006). Ministry of education strategic plan 2006- 2011. Nairobi: Government Press.

52. Republic of Kenya, 2008. Free secondary education programme. Nairobi: Government Printer.

53. Republic of Kenya, 2008. Free secondary education programme. Nairobi: Government Printer.

54. Robert, F \& Bernanke. B. (2013). Principles of Microeconomics, 5th edition. New York: McGraw Hill.

55. Swanson, R. A. (2013). Theory Building in Applied Disciplines. San Francisco, CA: Berrett-Koehler Publishers 
56. Tshewang R. (2018). A Study of Factors Influencing Students' Academic Performance in a Higher Secondary School in Bhutan. Monash University, Australia.

57. UNESCO. World Bank. (2006). Expanding opportunities and building competencies for young people: A new agenda for secondary education. Washington DC: The World Bank.

58. Wallace (1991), Education Management and Administration.

59. Wango, G. M. and Gatere, A. W. (2012).School finance management: Fiscal management to enhance governance and accountability. Nairobi: The Jomo Kenyatta Foundation.'

60. Waweru .P, N \& Orodho,A.J.(2013).Management practices and students' academic performance in national examinations in public secondary schools in Kiambu County. International Journal of Scientific Research. 5,(2), pp 472-479 February, 2014. www.recentscientific.com

61. Williams, Ellie. (2018, June 29). What Is the Meaning of Academic Performance? Work Chron.com. Retrieved from http://work.chron.com/meaning-academic performance-17332.html

62. Wushe, T., Ndlovu, D., \& Shenje, J. (2014). An analysis of basic management and financial skills by school development committees (SDC) in selected Harare schools. International Journal of Innovative Research in Advanced Engineering, 1(10), 378-386. 


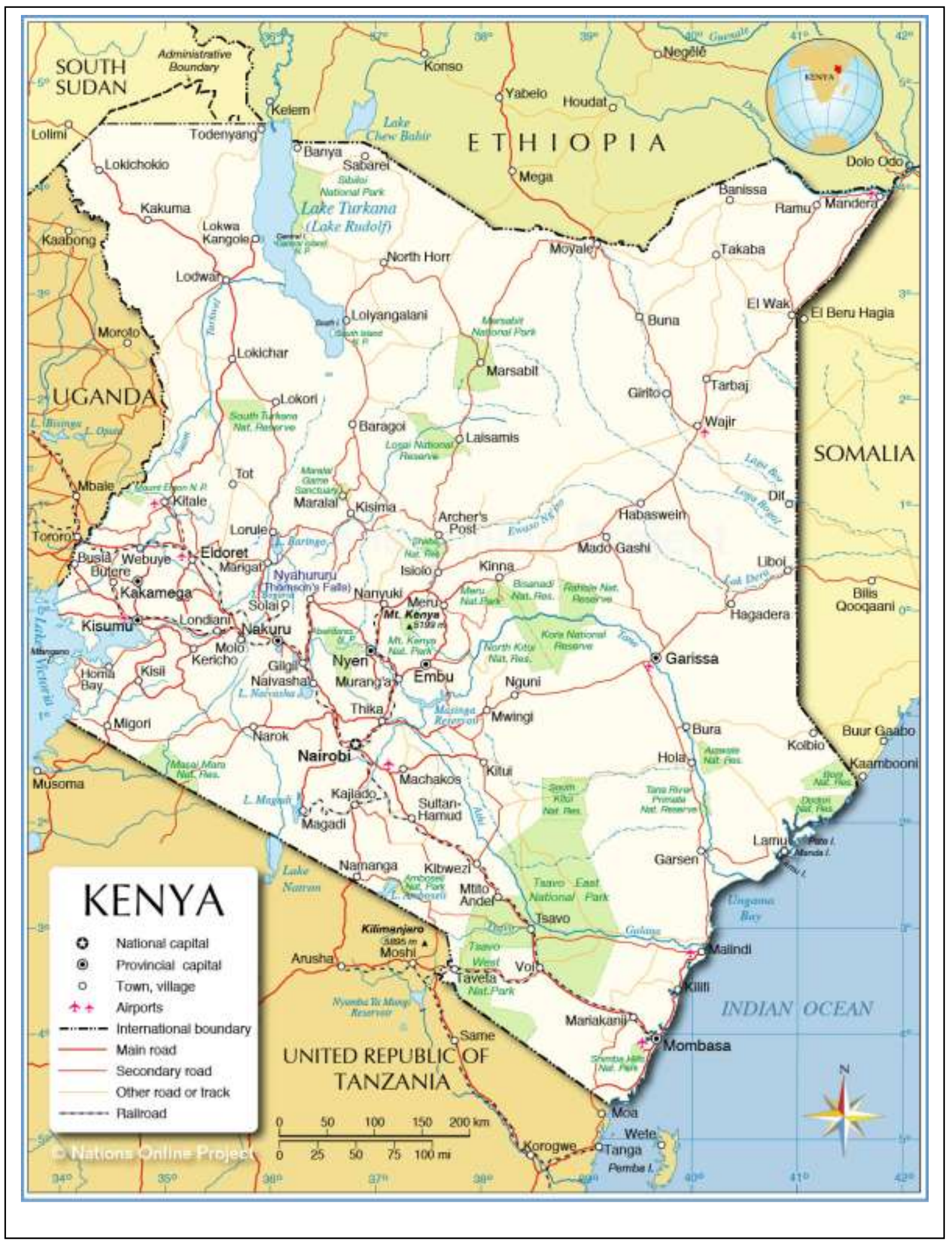

\section{APPENDICES}

\section{APPENDIX I: MAPS}

Figure 2- Map of Kenya: Showing Nairobi, location of Lang'ata Sub - county in Kenya.

Map based on a UN map. Source: UN Cartographic Section

Figure 3: Map of Nairobi County showing administrative Divisions 


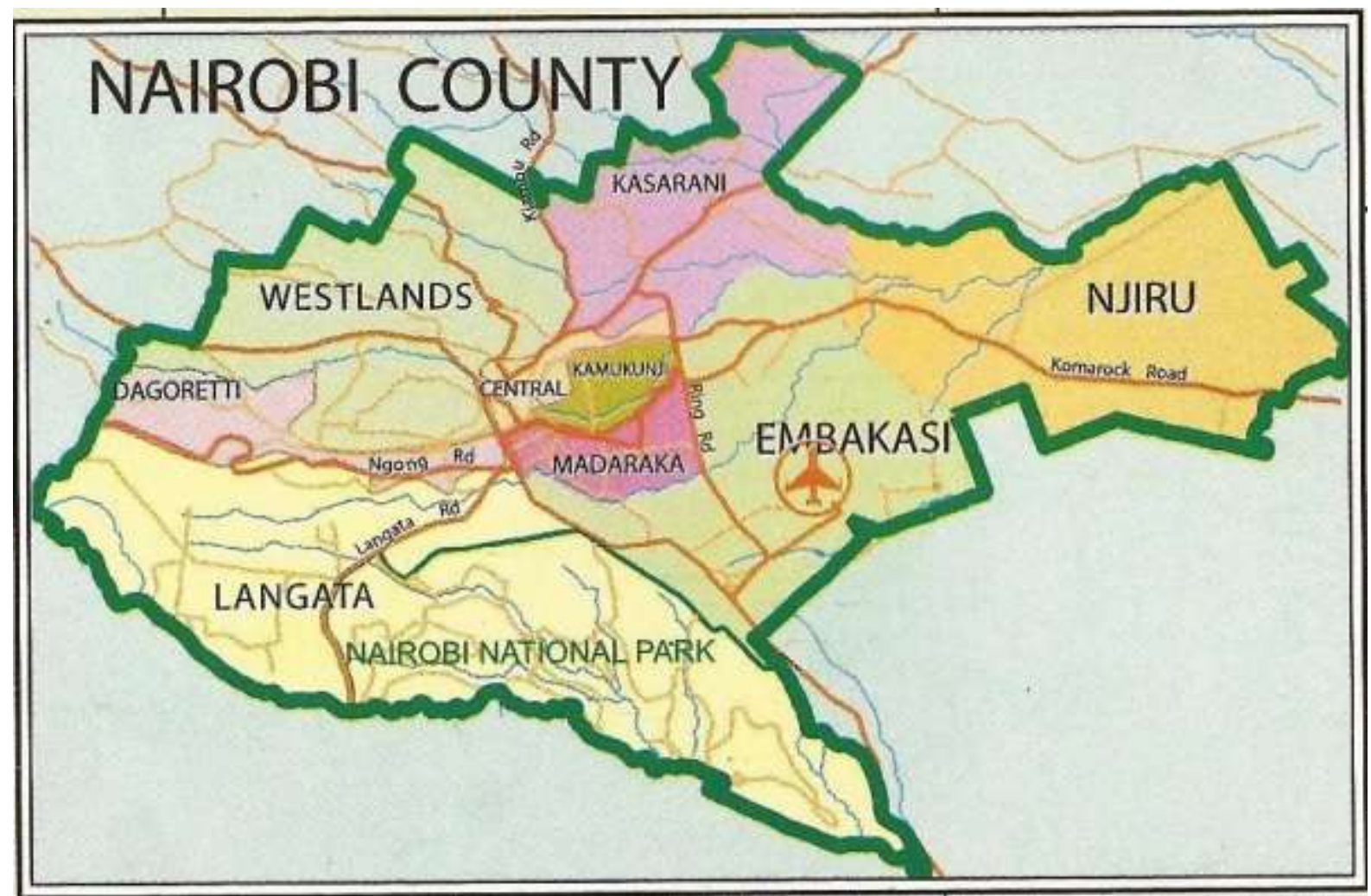

Source: Google Maps. Retrieved on 26th February, 2020.

\section{APPENDIX II: RESEARCH LETTER OF INTRODUCTION}

Dear respondent,

MASTERS OF EDUCATION RESEARCH ON FINANCIAL RESOURCE MANAGEMENT AND ITS INFLUENCE ON STUDENTS' ACADEMIC PERFORMANCE IN PUBLIC SECONDARY SCHOOLS IN LAN'GATA SUB-COUNTY, NAIROBI COUNTY, KENYA.

I am a postgraduate student in the Faculty of Education at the Catholic University of Eastern Africa. I am carrying out a research on the management of financial resources and their impact on the students' academic performance in public secondary schools. The topic of the research is financial resource management and students' academic performance in public secondary schools in Lang'ata sub-county, Nairobi County, Kenya.

To undertake this study, your feedback and suggestions are highly recommended. I kindly request your assistance in filling in the attached Questionnaire.

The Information you give will be treated with great confidence and will be used for academic purposes only.

Your assistant toward this undertaking is highly appreciated in advance.

Thank you

\section{APPENDIX III: RESEARCH QUESTIONNAIRE}

\section{Dear Respondent,}

I am a student at the Catholic University of Eastern Africa carrying out a research study on financial resource management and students' academic performance in public secondary schools in Lang'ata subcounty, Nairobi County, Kenya. You are among the respondents selected to take part in the study. The information given will be treated with utter most confidentiality and will only be used for academic purposes.

Kindly answer the following questions by ticking the appropriate box: [ ] 


\section{PART A: GENERAL INFORMATION}

1. What is your gender?

Male [ ]

2. What is your functional position in the school?

Administrator [ ] Financial Manager [ ] Accountant [ ] Other specify [ ]
Female [ ]

3. How long have you worked in the school?

Below 10 years [ ] $10-20$ years [ ] 21 -30 years ] 30 years and above [ ]

4. What is the Term Schedule covered by your school?

3 months [ ] 6 months [ ] 1 year [ ] More than 1 year [ ]

5. Do you think the secondary school administrators get enough time to prepare for the task prior to their appointment?

$$
\begin{array}{lll}
\text { Yes [ ] No [ ] } & \text { No }
\end{array}
$$

6. Who makes the final decisions in your school?

Top Management [ ] Finance Committee [ ] Finance Manager [ ] Other specify [ ]

\section{PART B: SPECIFIC QUESTION TO RESEARCH}

7. Relationship between financial resource management and students' academic performance in public secondary schools in Lang'ata sub - county, Nairobi County

Financial Resources have a number of purposes; indicate how important you think that each of the following is relevant for the institution in relation to students' academic performance

Using a rating scale of 1 to 5 please indicate the importance of the statement on the

Financial resource management and students' academic performance:-

\begin{tabular}{|c|c|c|c|c|c|}
\hline $\begin{array}{c}\text { Strongly agree } \\
5\end{array}$ & & gree & $\begin{array}{r}\text { strongly } \\
1\end{array}$ & agree & \\
\hline \multirow[t]{2}{*}{ Statement } & 5 & 4 & 3 & 2 & 1 \\
\hline & $\begin{array}{l}\text { Strongly } \\
\text { agree }\end{array}$ & Agree & Neutral & Disagree & $\begin{array}{l}\text { Strongly } \\
\text { disagree }\end{array}$ \\
\hline \multicolumn{6}{|l|}{$\begin{array}{l}\text { Financial resources are used to forecast the } \\
\text { future and therefore } \\
\text { good for planning }\end{array}$} \\
\hline \multicolumn{6}{|l|}{$\begin{array}{l}\text { Financial resources are used to control other } \\
\text { resources }\end{array}$} \\
\hline $\begin{array}{l}\text { Budgets are used to communicate to other } \\
\text { levels in the departments }\end{array}$ & & & & & \\
\hline
\end{tabular}




\begin{tabular}{|l|l|l|l|l|l|}
\hline $\begin{array}{l}\text { Financial resources are used to judge } \\
\text { students' academic performance }\end{array}$ & & & & & \\
\hline $\begin{array}{l}\text { They are used to motivate employees to do } \\
\text { better }\end{array}$ & & & & & \\
\hline
\end{tabular}

8. The extent to which financial resource management affect students' academic performance in public Secondary Schools in Lang'ata sub - county, Nairobi County

Using a rating scale of 1 to 5, please indicate the importance of the statement on the extent to which financial resource management affect students' academic performance.

$\begin{array}{ccccc}\text { Strongly agree } & \text { Agree } & \text { Neutral } & \text { Disagree } & \text { strongly disagree } \\ 5 & 4 & 3 & 2 & 1\end{array}$

\begin{tabular}{|l|l|l|l|l|l|}
\hline Statement & $\mathbf{5}$ & $\mathbf{4}$ & $\mathbf{3}$ & $\mathbf{2}$ & $\mathbf{1}$ \\
\hline $\begin{array}{l}\text { The institution issues budget guidelines } \\
\text { prior to the preparation of the budget }\end{array}$ & & Agree & Neutral & Disagree & $\begin{array}{l}\text { Strongly } \\
\text { Disagree }\end{array}$ \\
\hline $\begin{array}{l}\text { All the staff participate in the } \\
\text { preparation of the budget and } \\
\text { discussions within their departments }\end{array}$ & & & & & \\
\hline $\begin{array}{l}\text { Planning is important to the success of } \\
\text { the students in examinations }\end{array}$ & & & & & \\
\hline $\begin{array}{l}\text { There is proper communication during } \\
\text { the process of teaching and learning }\end{array}$ & & & & & \\
\hline $\begin{array}{l}\text { Support provided to the subordinate } \\
\text { staff during the school Term is effective }\end{array}$ & & & & & \\
\hline $\begin{array}{l}\text { Coordination among the various } \\
\text { departments during the school Term } \\
\text { improve academic performance }\end{array}$ & & & & & \\
\hline $\begin{array}{l}\text { The management can be able to } \\
\text { implementation challenges of budget }\end{array}$ & & & & & \\
\hline
\end{tabular}

9. Challenges Principals of Public Secondary Schools face in the management of finances Using a rating scale of 1 to 5 please indicate the importance of the statement on the challenges:-

Strongly agree Agree $\quad$ Neutral Disagree $\quad$ Strongly disagree 


\begin{tabular}{|c|c|c|c|c|c|}
\hline Statement & 5 & 4 & 3 & 2 & 1 \\
\hline & $\begin{array}{l}\text { Strongly } \\
\text { Agree }\end{array}$ & Agree & Neutral & Disagree & $\begin{array}{l}\text { Strongly } \\
\text { disagree }\end{array}$ \\
\hline \multicolumn{6}{|l|}{$\begin{array}{l}\text { In some cases budget include unattainable } \\
\text { targets or standards }\end{array}$} \\
\hline \multicolumn{6}{|l|}{$\begin{array}{l}\text { Insufficient funds allocation affect the } \\
\text { implementation of the school programs }\end{array}$} \\
\hline \multicolumn{6}{|l|}{$\begin{array}{l}\text { Inability of departments to utilize the } \\
\text { allocated funds hinders the effective } \\
\text { teaching and learning }\end{array}$} \\
\hline \multicolumn{6}{|l|}{$\begin{array}{l}\text { The methods used to allocate funds to the } \\
\text { departments are unsatisfactory }\end{array}$} \\
\hline \multicolumn{6}{|l|}{$\begin{array}{l}\text { Reforms in school financial management } \\
\text { come up with new rules which affect } \\
\text { students' academic performance }\end{array}$} \\
\hline comments & you & & & like & to \\
\hline
\end{tabular}

\section{Thank you}

\section{APPENDIX IV: RESEARCH QUESTIONNAIRE FOR SCHOOL HEADS}

\section{Dear Respondent,}

I am a student at the Catholic University of Eastern Africa carrying out a research study on financial resource management and students' academic performance in public secondary schools in Lang'ata subcounty, Nairobi County, Kenya. You are among the respondents selected to take part in the study. The information given will be treated with utter most confidentiality and will only be used for academic purposes.

Kindly answer the following questions by ticking the appropriate box: [ ]

\section{PART A: GENERAL INFORMATION}

1. What is your gender?

Male [ ]

Female [ ]

2. What is your functional position in the school?

Administrator [ ] School Manager [ ] Headmaster [ ] Other specify [ ]

3. How long have you worked in the school? 
Below 10 years [ ] 10 -20 years [ ] 21 -30 years ] 30 years and above [ ]

4. What is the Term Schedule covered by your school?

3 months [ ] 6 months [ ] 1 year [ ] More than 1 year [ ]

5. Do you think the secondary school administrators get enough time to prepare for the task prior to their appointment?

$$
\text { Yes [ ] No [ ] }
$$

6. Who makes the final decisions in your school?

Top Management [ ] Finance Committee [ ] Finance Manager [ ] Other specify [ ]

\section{PART B: SPECIFIC QUESTION TO RESEARCH}

7. Relationship between financial resource management and students' academic performance in public secondary schools in Lang'ata sub - county, Nairobi County

Financial Resources have a number of purposes; indicate how important you think that each of the following is relevant for the institution in relation to students' academic performance

Using a rating scale of 1 to 5 please indicate the importance of the statement on the

Financial resource management and students' academic performance:-

$\begin{array}{ccccc}\text { Strongly agree } & \text { Agree } & \text { Neutral } & \text { Disagree } & \text { strongly disagree } \\ 5 & 4 & 3 & 2 & 1\end{array}$

\begin{tabular}{|l|l|l|l|l|l|}
\hline Statement & $\mathbf{5}$ & $\mathbf{4}$ & $\mathbf{3}$ & $\mathbf{2}$ & $\mathbf{1}$ \\
\hline $\begin{array}{l}\text { Strongly } \\
\text { agree }\end{array}$ & Agree & Neutral & Disagree & $\begin{array}{l}\text { Strongly } \\
\text { disagree }\end{array}$ \\
\hline $\begin{array}{l}\text { Financial resources are used to forecast the } \\
\text { good for planning }\end{array}$ & & & & & \\
\hline $\begin{array}{l}\text { Financial resources are used to control other } \\
\text { resources }\end{array}$ & & & & & \\
\hline $\begin{array}{l}\text { Budgets are used to communicate to other } \\
\text { levels in the departments }\end{array}$ & & & & & \\
\hline $\begin{array}{l}\text { Financial resources are used to judge } \\
\text { students' academic performance }\end{array}$ & & & & & \\
\hline $\begin{array}{l}\text { Financial resources are used to motivate } \\
\text { employees to do better }\end{array}$ & & & & & \\
\hline
\end{tabular}


8. The extent to which financial resource management affect students' academic performance in public Secondary Schools in Lang'ata sub - county, Nairobi County

Using a rating scale of 1 to 5, please indicate the importance of the statement on the extent to which financial resource management affect students' academic performance.

Strongly agree

5
Agree

4
Neutral

3
Disagree

2 strongly disagree

1

\begin{tabular}{|c|c|c|c|c|c|}
\hline Statement & 5 & 4 & 3 & 2 & 1 \\
\hline & $\begin{array}{l}\text { Strongly } \\
\text { Agree }\end{array}$ & Agree & Neutral & Disagree & $\begin{array}{l}\text { Strongly } \\
\text { Disagree }\end{array}$ \\
\hline $\begin{array}{l}\text { The institution issues budget guidelines } \\
\text { prior to the preparation of the budget }\end{array}$ & & & & & \\
\hline $\begin{array}{l}\text { All the staff participate in the } \\
\text { preparation of the budget and } \\
\text { discussions within their departments }\end{array}$ & & & & & \\
\hline $\begin{array}{l}\text { Planning is important to the success of } \\
\text { the students in examinations }\end{array}$ & & & & & \\
\hline $\begin{array}{l}\text { There is proper communication during } \\
\text { the process of teaching and learning }\end{array}$ & & & & & \\
\hline $\begin{array}{l}\text { Support provided to the subordinate } \\
\text { staff during the school Term is effective }\end{array}$ & & & & & \\
\hline $\begin{array}{l}\text { Coordination among the various } \\
\text { departments during the school Term } \\
\text { improve academic performance }\end{array}$ & & & & & \\
\hline $\begin{array}{l}\text { The management can be able to } \\
\text { overcome the challenges of budget } \\
\text { implementation }\end{array}$ & & & & & \\
\hline
\end{tabular}

9. Challenges Principals of Public Secondary Schools face in the management of finances Using a rating scale of 1 to 5 please indicate the importance of the statement on the challenges:-

$\begin{array}{ccccc}\text { Strongly agree } & \text { Agree } & \text { Neutral } & \text { Disagree } & \text { Strongly disagree } \\ 5 & 4 & 3 & 2 & 1\end{array}$




\begin{tabular}{|l|l|l|l|l|l|}
\hline Statement & $\mathbf{5}$ & $\mathbf{4}$ & $\mathbf{3}$ & $\mathbf{2}$ & $\mathbf{1}$ \\
\hline & $\begin{array}{l}\text { Strongly } \\
\text { Agree }\end{array}$ & Agree & Neutral & Disagree & $\begin{array}{l}\text { Strongly } \\
\text { disagree }\end{array}$ \\
\hline $\begin{array}{l}\text { Budgets in public secondary schools } \\
\text { include unattainable targets or standards }\end{array}$ & & & & & \\
\hline $\begin{array}{l}\text { Insufficient funds allocation affect the } \\
\text { implementation of the school programs }\end{array}$ & & & & & \\
\hline $\begin{array}{l}\text { Inability of departments to utilize the } \\
\text { allocated funds hinders effective teaching } \\
\text { and learning }\end{array}$ & & & & & \\
\hline $\begin{array}{l}\text { The methods used to allocate funds to the } \\
\text { departments are unsatisfactory }\end{array}$ & & & & & \\
\hline $\begin{array}{l}\text { Reforms in school financial management } \\
\text { come up with new rules which affect } \\
\text { students' academic performance }\end{array}$ & & & & & \\
\hline
\end{tabular}

Any additional comments you would like to provide

Thank you

APPENDIX V: INTERVIEW SCHEDULE FOR SCHOOL HEADS

\section{Interview Schedule for School Administrators/Principals/Headmasters/Headmistresses}

1. Good afternoon Sir/Madam. Please tell me how the budget of your school is prepared.

a) How is the school principal involved in the preparation of the budget?

b) How is the Board of Management involved in the budget process?

c) How is the Finance Committee involved in the process of budgeting?

d) Is there a finance policy in the school?

e) Does it detail how the budget process should be followed?

f) How do you get information for the budget?

g) Who reviews the budget before it is presented to the school board for approval?

h) Would you say your school does pre- control, concurrent control and post -control of the budget?

i) How does the budget affect the academic performance in the school?

2. How does the school principal ensure that the school's expenditure is in line with the budgeted finances?

a) Is the school principal fully involved in the implementation of the school budget?

b) Is the actual expenditure compared to the budgeted finances in the course of budget implementation?

c) How are variances in the budget identified?

d) How are they reported to the finance committee and the Board of Management (BOM)?

e) How are corrective measures taken when there are significant variances in the budget?

f) How does effective financial management affect students' academic performance?

3. Does actual expenditure sometimes exceed or fall far below from the budget? 

a) How often does this happen?
b) What are the most common reasons for this?
c) How does the school principal contribute to the variances in the school budget?
d) How are budget variances corrected - such that they do not happen again?
e) What challenges do you experience in the implementation of the school budgetary allocations?
f) Do the challenges adversely affect the students' academic performance?

\section{APPENDIX VI: INTERVIEW SCHEDULE}

\section{Interview Schedule for School Accountants/Cashiers/Bursars}

1. Good afternoon Sir/Madam. Please tell me how the budget of your school is prepared.

a) How is the Finance Committee involved in the process of budgeting?

b) Is there a finance policy in the school?

c) Does it detail how the budget process should be followed?

e) How do you get information for the budget?

f) Who reviews the budget before it is presented to the school board for approval?

g) Would you say your school does pre- control, concurrent control and post -control of the budget?

h) How does the budget affect the academic performance in the school?

2. How do you ensure that the school's expenditure is in line with the budgeted amounts?

a) Is the actual expenditure compared to the budgeted amounts in the course of budget implementation?

c) How are variances in the budget identified?

d) How are they reported to the finance committee and the Board of Management (BOM)?

e) How are corrective measures taken when there are significant variances in the budget?

3. Does actual expenditure sometimes exceed or fall far below from the budget?

a) How often does this happen?

b) What are the most common reasons for this?

c) How are budget variances corrected - such that they do not happen again?

d) What challenges do you experience in the implementation of the school budgetary allocations?

e) Do the challenges adversely affect the students' academic performance?

\section{APPENDIX VII: RESEARCH BUDGET}

\begin{tabular}{|c|c|c|c|c|c|}
\hline \multicolumn{6}{|c|}{ RSEARCH BUDGET } \\
\hline \multirow{3}{*}{\multicolumn{6}{|c|}{$\begin{array}{l}\text { PROJECT TITLE: FINANCIAL RESOURCE MANAGEMENT AND ITS INFLUENCE } \\
\text { ON STUDENTS ACADEMIC PERFORMANCE IN PUBLIC SECONDARY SCHOOLS } \\
\text { IN LANGATA SUB-COUNTY, NAIROBI COUNTY-KENYA }\end{array}$}} \\
\hline & & & & & \\
\hline & & & & & \\
\hline \multicolumn{6}{|c|}{ PROJECT PERIOD: 1 YEAR (2020/2021) } \\
\hline \multicolumn{6}{|c|}{ BUDGET PERIOD: 1 YEAR $(2020 / 2021)$} \\
\hline \multirow[t]{2}{*}{$\mathbf{S} / \mathbf{N}$} & \multirow[t]{2}{*}{ ITEM } & \multirow[t]{2}{*}{ DESCRIPTION } & \multirow[t]{2}{*}{ DURATION } & \multicolumn{2}{|l|}{ AMOUNT REQUIRED } \\
\hline & & & & QUANTITY PRICE & TOTAL \\
\hline \multirow[t]{3}{*}{1.} & Senior & School & PROJECT & 10 & NIL \\
\hline & Personnel & Principals and & PERIOD: 1 & participants & \\
\hline & & $\begin{array}{l}\text { Board of } \\
\text { Management }\end{array}$ & $\begin{array}{l}\text { YEAR } \\
(2020 / 2021)\end{array}$ & & \\
\hline \multirow[t]{3}{*}{2.} & Other & Bursars, Heads & PROJECT & 50 & NIL \\
\hline & Personnel & of Departments, & PERIOD: 1 & participants & \\
\hline & & Teachers & YEAR & & \\
\hline
\end{tabular}




\begin{tabular}{|c|c|c|c|c|c|c|}
\hline & & & $(2020 / 2021)$ & & & \\
\hline & Students & Students' & PROJECT & 200 & & NIL \\
\hline & & representatives & PERIOD: 1 & participants & & \\
\hline & & & $\begin{array}{l}\text { YEAR } \\
(2020 / 2021)\end{array}$ & & & \\
\hline \multirow[t]{4}{*}{3.} & Equipment & Research Tools: & PROJECT & 260 copies & Ksh. 30 & Ksh.7,800 \\
\hline & & Questionnaires, & $\begin{array}{l}\text { PERIOD: } 1 \\
\text { YEAR } \\
(2020 / 2021)\end{array}$ & & each & \\
\hline & & Interview & & 60 copies & Ksh. 30 & Ksh.1,800 \\
\hline & & Schedules & & & & \\
\hline \multirow[t]{4}{*}{4.} & Travel & Researcher & PROJECT & 20 trips & Ksh. & Ksh. 12,000 \\
\hline & & & PERIOD: 1 & & 600 per & \\
\hline & & & YEAR & & & \\
\hline & & & $(2020 / 2021)$ & & & \\
\hline \multirow[t]{4}{*}{5.} & Materials and & Stationery & PROJECT & & & Ksh. 3,200 \\
\hline & Supplies & & PERIOD: 1 & & & \\
\hline & & & YEAR & & & \\
\hline & & & $(2020 / 2021)$ & & & \\
\hline \multirow[t]{3}{*}{6.} & Consultant & Typesetting & PROJECT & 5 Times & Ksh. & Ksh. 5000 \\
\hline & & & PERIOD: 1 & & 1,000 & \\
\hline & & & $\begin{array}{l}\text { YEAR } \\
(2020 / 2021)\end{array}$ & & & \\
\hline \multirow[t]{12}{*}{7.} & Printing & Proposal & PROJECT & 5 copies & Ksh. & Ksh. 1,440 \\
\hline & & Printing & PERIOD: 1 & & 288 & \\
\hline & & & YEAR & & each & \\
\hline & & & $(2020 / 2021)$ & & & \\
\hline & & Thesis Printing & PROJECT & 6 copies & Ksh. & Ksh. 6,420 \\
\hline & & & PERIOD: 1 & & 1,070 & \\
\hline & & & YEAR & & each & \\
\hline & & & $(2020 / 2021)$ & & & \\
\hline & & Thesis Binding & PROJECT & 5 copies & Ksh. & Ksh. 1,250 \\
\hline & & & PERIOD: 1 & & 250 & \\
\hline & & & YEAR & & each & \\
\hline & & & $(2020 / 2021)$ & & & \\
\hline \multirow[t]{4}{*}{8} & Licencing & Research & PROJECT & 1 licence & & Ksh. 1,000 \\
\hline & & Licence & PERIOD: 1 & & & \\
\hline & & & YEAR & & & \\
\hline & & & $(2020 / 2021)$ & & & \\
\hline \multirow[t]{4}{*}{9.} & Dissemination & & PROJECT & & & NIL \\
\hline & Costs & & PERIOD: 1 & & & \\
\hline & & & YEAR & & & \\
\hline & & & $(2020 / 2021)$ & & & \\
\hline
\end{tabular}




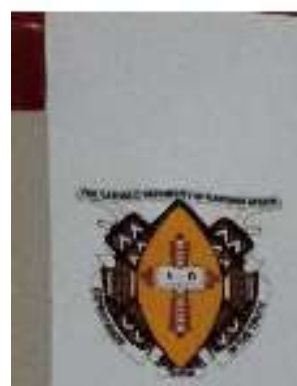

\section{Faculty of Education \\ Department of Postgraduate Studies in Education}

THE CATHOLIC UNIVERSITY OF EASTERN AFRICA

Our Ref: CUEA/DVC-ACAD/FOE/PGSE/NACOSTI/011/SEPTEMBER, 2020

$29^{\text {th }}$ SEPTEMBER, 2020

THE DIRECTOR,

NATIONAL COMMISSION FOR SCIENCE, TECHNOLOGY AND INNOVATION (NACOSTI)

NAIROBI, KENYA

RE: MARTIN OKOTH ODIDE REG. NO. MED 1035628

I wish to introduce to you MARTIN OKOTH a final year Master of Education of Education student at The Catholic University of Eastern Africa, Nairobi - Kenya; and request you to assist him

accomplish her academic research requirements.

Okoth's area of specialization is in Educational Administration and Planning. Every student in the programme is requireo to conduct research, write a report/dissertation and submit it for examination in the final years of study. Accordingly, Okoth's research proposal has seen approved and he will conduct research on the following topic:

"Financial Resource Management and its Influence on Students Academic Performance in Public Secondary Schools in Langata SubCounty, Nairobi County-Kenya"

Thanking you in advance for according Martin Okoth the assistance he may require to conduct her research successfully.
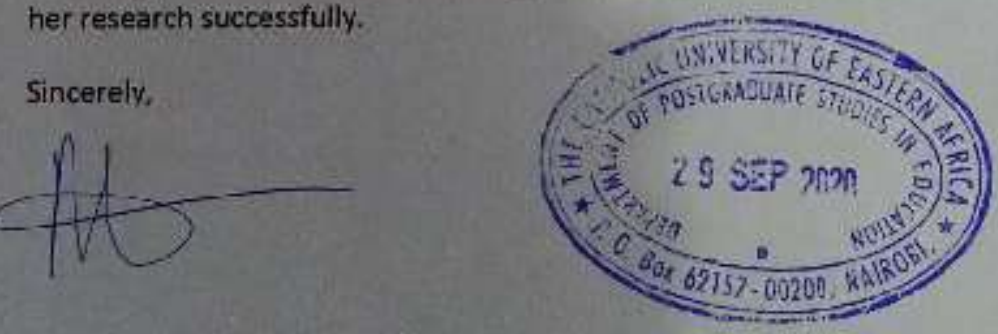

PROF. MARCELLA MOMANYI HEAD OF DEPARTMENT - POSTGRADUATE STUDIES IN EDUCATION

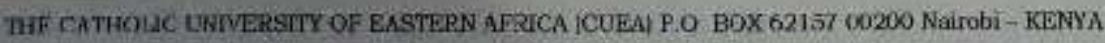

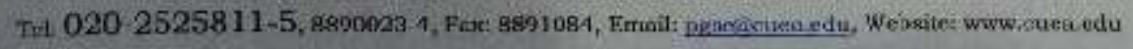

\section{APPENDIX IX: DECLARATION FORM}




\section{DECI.ARATION}

I the undersigned declare that this proposal is my original work and has never been submitted to any university or any other academic institution for award of any mark or academic credit. All the other sources cited in the text have been dully acknowledged in the reference section

Name: Bro. Martin Okoth Odide

Reg. M.ED 1035628

Signature-

Bate

This proposal has been submitted for reveew and examination with our approval as the University Supervisors.

Sr. Dr. Klizabeth Nduku,

Faculty of Lducation,

Department of Pnstymaduate Studies,

The Catholic University or Eastern Africa

Signature

Date-.......................-

Dr. Jared Anyona Ntabo (PhD., M.Fhil., B. Ed)

Lecturer, Researsh, Monitoring \& Evaluation Studies Department of Fostgraduate Studies in Fducation Faculty of Eduvation,

The Catholic University of Eastern Airica,

R.0. Box 62137 - 00200 Nairobi, Keny:

Tel. $(+254)$ o727765179/ 0713188980

E mal: jarantabsogunailioom/_inituboiglomeri.cdu

A thetro:

Signature.

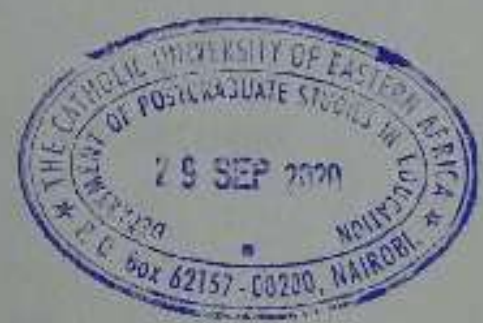

Date. 


\section{APPENDIX X: RESEARCH LICENCE INVOICE}

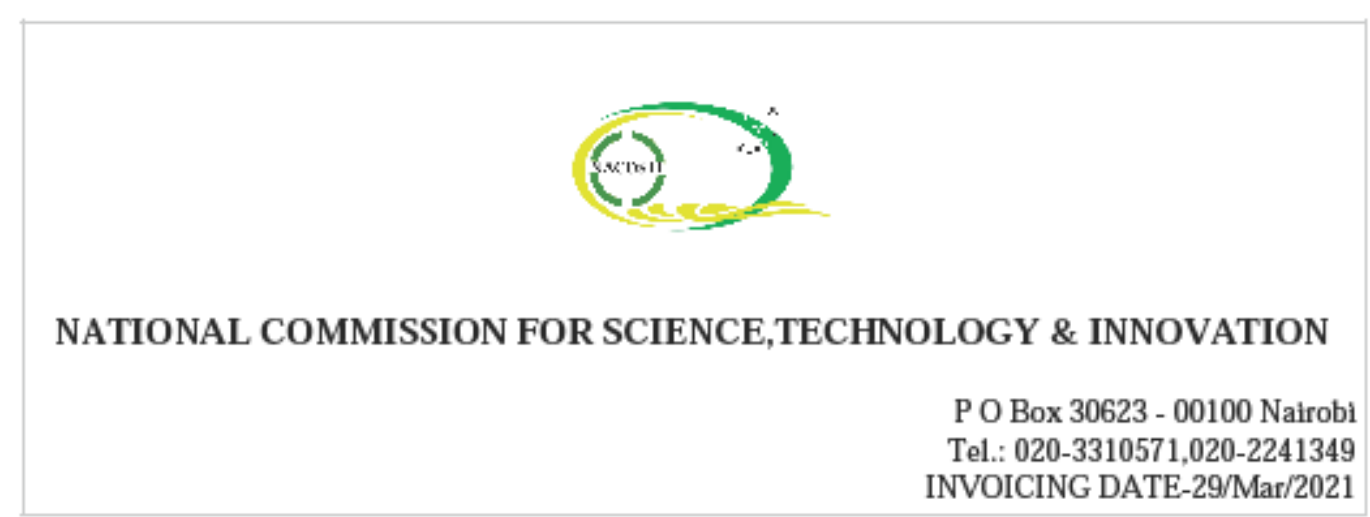

INVOICE: 10373

INVOICE TO:

MARTIN OKOTH ODIDE

Kenya

\begin{tabular}{|c|c|c|c|}
\hline ITEM DESCRIPTION & $\begin{array}{c}\text { CATEGORY OF } \\
\text { RESEARCH }\end{array}$ & PROCESSING FEE & $\begin{array}{c}\text { TOTAL } \\
\text { AMOUNT } \\
\text { (KSHS) }\end{array}$ \\
\hline $\begin{array}{c}\text { Application Fees For - Research (Masters) } \\
\text { Humanities and Social Sciences - Kenyan } \\
\text { Citizens }\end{array}$ & Research (Masters) & 1,000 & 1,000 \\
\hline & & & \\
\hline & \multicolumn{2}{|r|}{ Total Amount Payable (Kshs) } & 1,000 \\
\hline
\end{tabular}

Issued By : -

Payment to be made to our account as detailed below:

East African Citizens - Kenya Shillings Account

Mobile money: Mpesa Express or Paybill Number 680907

or

Account Name: National Commission for Science, Technology and Innovation

Account No.: 1104162547

Bank: KCB Bank, Kipande House Branch, NAIROBI

Non-Kenyans - US Dollar Account

Account Name: National Commission for Science, Technology and Innovation Account No.: 1001467375

Bank: NCBA Bank, City Centre Branch, NAIROBI 


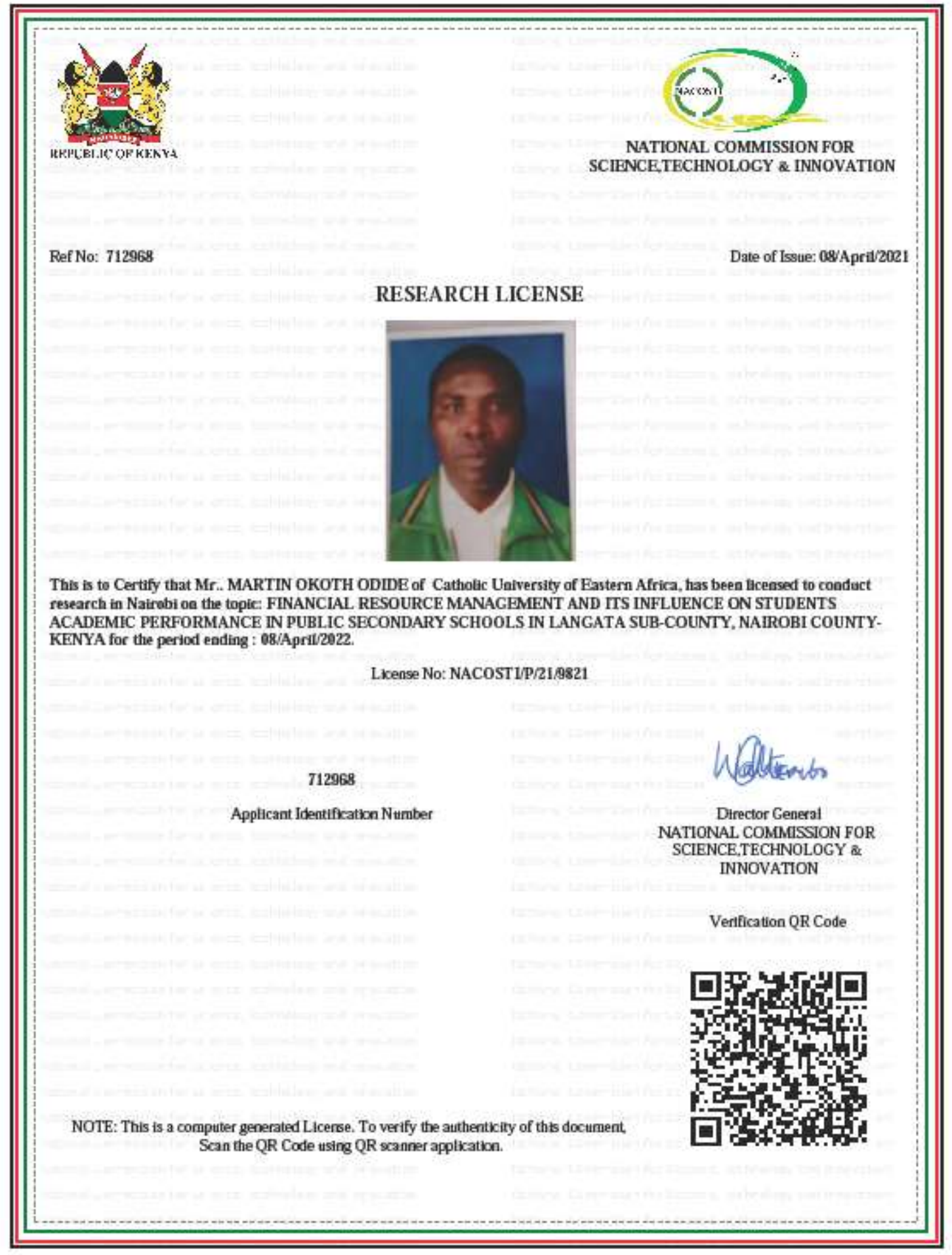

